Leticia Cabrini Girotto

\title{
Preceptores do Sistema Único de Saúde: como percebem seu papel em processos educacionais na saúde
}

Dissertação apresentada à Faculdade de Medicina da Universidade de São Paulo para obtenção do título de Mestre em Ciências

Programa de: Ciência Médicas

Área de concentração: Educação e Saúde Orientadora: Prof. ${ }^{\underline{a}}$ Dr. ${ }^{\underline{a}}$ Patrícia Zen Tempski 
Leticia Cabrini Girotto

\section{Preceptores do Sistema Único de Saúde: como percebem seu papel em processos educacionais na saúde}

Dissertação apresentada à Faculdade de Medicina da Universidade de São Paulo para obtenção do título de Mestre em Ciências

Programa de: Ciência Médicas Área de concentração: Educação e Saúde Orientadora: Prof. ${ }^{a}$ Dr. ${ }^{a}$ Patrícia Zen Tempski 
Dados Internacionais de Catalogação na Publicação (CIP)

Preparada pela Biblioteca da

Faculdade de Medicina da Universidade de São Paulo

Creprodução autorizada pelo autor

\section{Girotto, Leticia Cabrini}

Preceptores do Sistema Único de Saúde : como percebem seu papel em processos educacionais na saúde / Leticia Cabrini Girotto. -- São Paulo, 2016.

Dissertação(mestrado)--Faculdade de Medicina da Universidade de São Paulo.

Programa de Ciências Médicas. Área de Concentração: Educação e Saúde. Orientadora: Patrícia Zen Tempski.

Descritores: 1.Preceptoria 2.Capacitação de recursos humanos em saúde 3.Competência profissional 4.Serviços de integração docente-assistencial 5.Sistema Único de Saúde 6.Estudos transversais 
Dedico este trabalho a todos os preceptores, profissionais que dedicam seus dias à formação de outros, acreditando na possibilidade de superação constante.

Dedico a você João Eduardo, porque cada linha deste trabalho tem uma pitada da sua participação e o sabor do sucesso, como em todos os momentos de nossas vidas, é compartilhado. Dedico esta conquista a você, por tornar meus dias mais leves, por me ensinar a ver sempre o lado bom das coisas, por me fazer feliz e, assim uma pessoa methor e, claro, por ter sido um dos principais responsáveis por esta realização. 


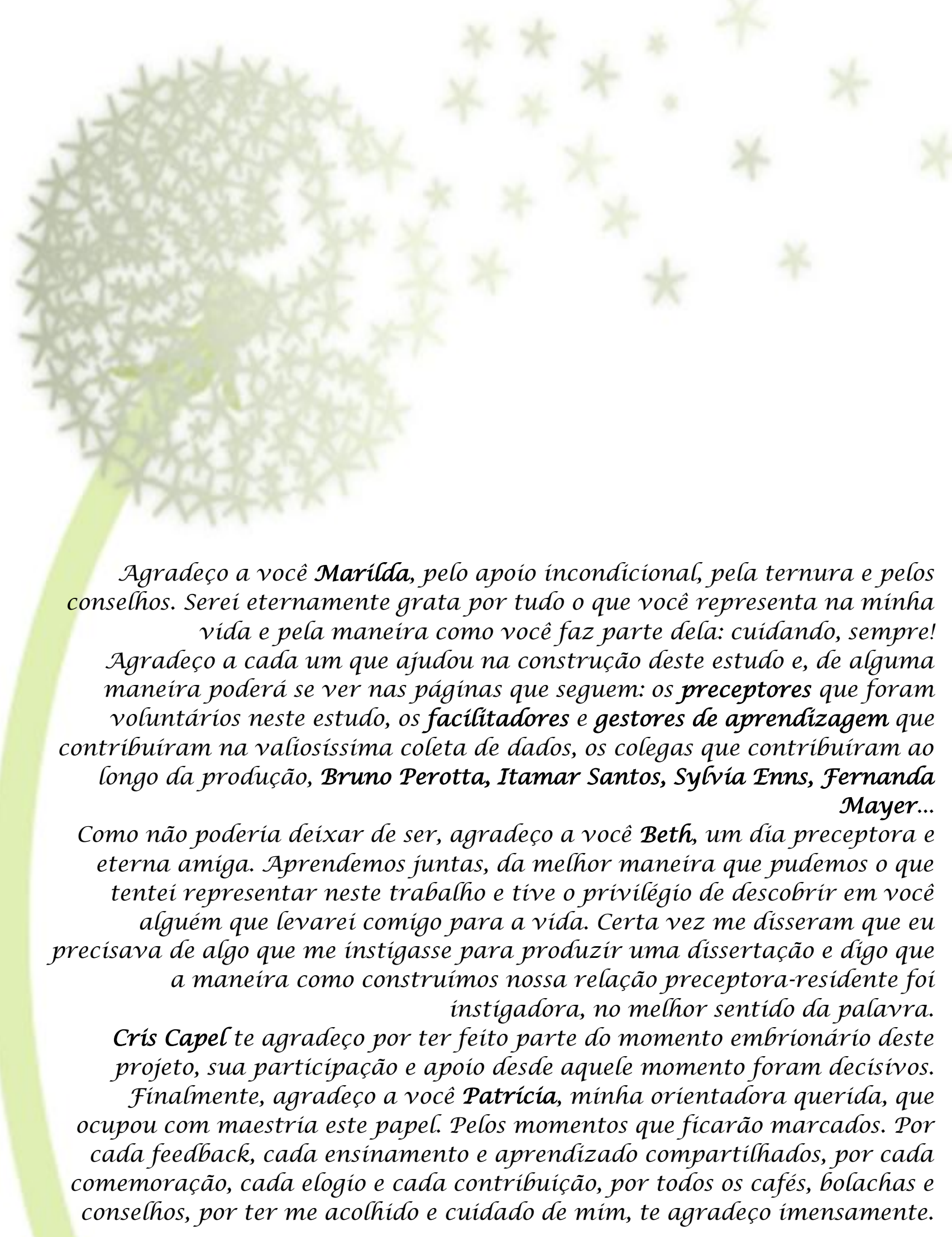


"O príncipal objetivo da educação é criar pessoas capazes de fazer coisas novas e não simplesmente repetir o que outras gerações fizeram."

Jean Piaget 


\section{NORMALIZAÇÃO ADOTADA}

Esta dissertação está de acordo com as seguintes normas, em vigor no momento desta publicação:

Referências: adaptado de International Committee of Medical Journals Editors (Vancouver)

Universidade de São Paulo Faculdade de Medicina Divisão de Biblioteca e Documentação. Guia de apresentação de dissertações, teses e monografias Elaborado por Anneliese Carneiro da Cunha, Maria Júlia de A. L. Freddi, Maria F. Crestana, Marinalva de Souza Aragão, Suely Campos Cardoso, Valéria Vilhena. $3^{\text {a }}$ ed. São Paulo. Divisão de Biblioteca e Documentação; 2011.

Abreviatura dos títulos dos periódicos de acordo com List of Journals Indexed in Index Medicus. 


\section{Sumário}

LISTA DE ABREVIATURAS E SIGLAS

LISTA DE FIGURAS

LISTA DE TABELAS

LISTA DE ANEXOS

Resumo

Abstract

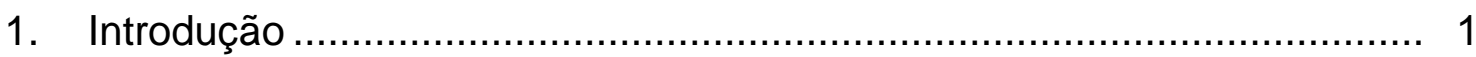

1.1. O Preceptor e a preceptoria ................................................ 2

1.2. A educação em serviço ..................................................... 6

1.3. A educação de adultos....................................................... 17

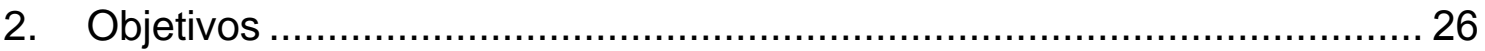

2.1. Objetivo Geral .................................................................... 26

2.2. Objetivos Específicos .......................................................... 26

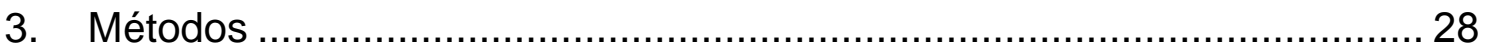

3.1. Descrição do estudo e coleta de dados ......................................... 28

3.2. Construção e sintaxe do instrumento de coleta de dados.................. 30

3.3. Análise dos dados .................................................................. 31

3.3.1. Análise dos dados quantitativos......................................... 31

3.3.2. Análise dos dados qualitativos .............................................. 33

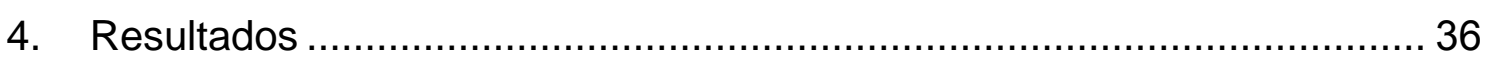

4.1. Caracterização da amostra ..................................................... 36

4.1.1. Caracterização da amostra por região ................................ 40

4.2. Análise de confiabilidade do instrumento de coleta de dados

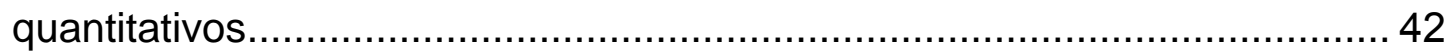

4.3. Análise quantitativa da percepção dos preceptores acerca da

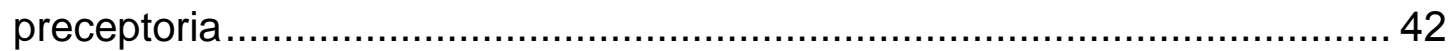

4.3.1. Análise de item ........................................................ 42

4.3.2. Análise fatorial ........................................................... 50

4.4. Análise qualitativa da percepção dos preceptores acerca da

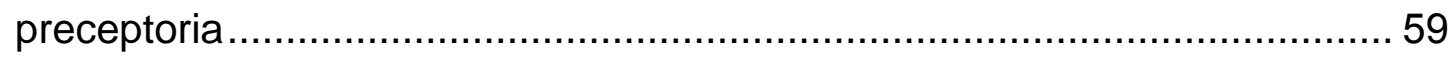

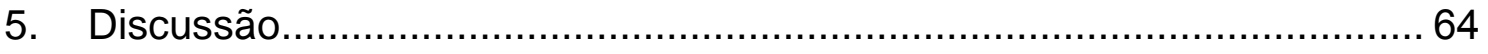

5.1. Considerações finais .......................................................... 78

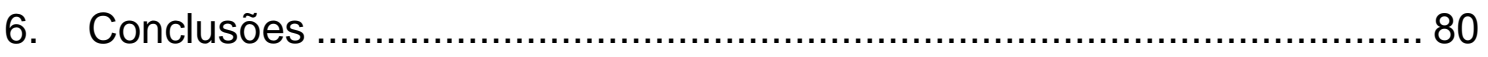

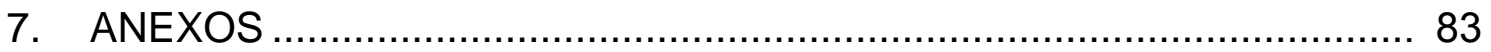

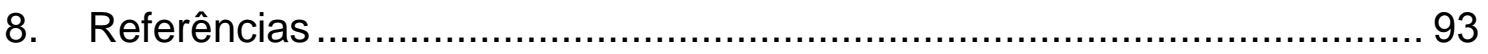




\section{LISTA DE ABREVIATURAS E SIGLAS}

CONASS - Conselho Nacional de Secretários de Saúde

CONASEMS - Conselho Nacional de Secretários Municipais de Saúde

DCN - Diretrizes Curriculares Nacionais

DeCS - Descritores em Ciências da Saúde

IDA - Integração Docente-Assistencial

IEP/HSL - Instituto de Ensino e Pesquisa do Hospital Sírio Libanês

IES - Instituições de Ensino Superior

SUS - Sistema Único de Saúde

OPAS - Organização Panamericana de Saúde

OMS - Organização Mundial da Saúde

WFME - World Federation for Medical Education

UNICEF - United Nations Children's Fund

CINAEM - Comissão Interinstitucional de Avaliação do Ensino Médico

WHO - World Health Organization

CEP - Comitê de Ética em Pesquisa

FMUSP - Faculdade de Medicina da Universidade de São Paulo

TCLE - Termo de Consentimento Livre e Esclarecido

EPES - Especialização em Processos Educacionais na Saúde 


\section{LISTA DE FIGURAS}

Figura 1 - Linha do tempo da educação em serviço........................................ 16

Figura 2 - Regiões de saúde que sediaram a segunda edição do Curso de

Especialização em Educação na Saúde para Preceptores do SUS, IEP/HSL

Figura 3 - Fluxograma de participantes e perdas do estudo

Figura 4 - Distribuição percentual dos participantes quanto à área de graduação

Figura 5 - Distribuição dos participantes por área de atuação ......................... 38

Figura 6 - Análise de item das afirmativas 1 a 10........................................ 43

Figura 7 - Análise de item das afirmativas 11 a 20...................................... 44

Figura 8 - Análise de item das afirmativas 21 a 30..................................... 45

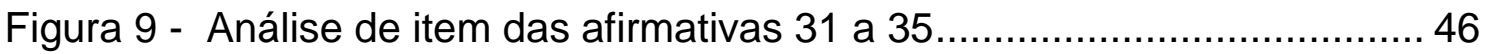

Figura 10 - Análise fatorial do instrumento de coleta de dados ........................51 


\section{LISTA DE TABELAS}

Tabela 1 - Distribuição de concluintes e respondentes por região e representatividade de cada região no estudo …………….................... 39

Tabela 2 - Distribuição regional dos respondentes por sexo............................ 40

Tabela 3 - Distribuição regional dos respondentes por curso de graduação.... 41

Tabela 4 - Distribuição regional dos respondentes por titulação ...................... 42

Tabela 5 - Distribuição de respondentes conforme percepção por item .......... 47

Tabela 6 - Análise fatorial do instrumento de coleta de dados ......................... 50

Tabela 7 - Fatores delimitados a partir da análise fatorial ............................... 53

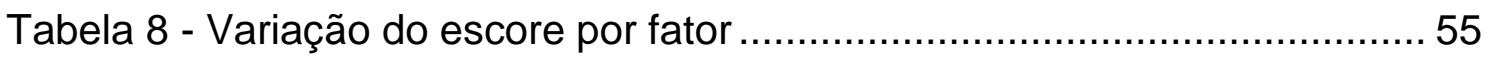

Tabela 9 - Comparação das médias dos fatores por sexo ………………….... 55

Tabela 10 - Comparação das médias dos fatores por região............................56

Tabela 11 - Comparação das médias dos fatores por curso de graduação ..... 57

Tabela 12 - Comparação das médias dos fatores por titulação ........................ 58

Tabela 13 - Comparação das médias dos fatores por área de atuação .............59

Tabela 14 - Análise qualitativa das respostas à pergunta "O que é preceptoria?"

Tabela 15 - Análise qualitativa das respostas à pergunta "Qual é a sua percepção do papel social desempenhado pelo preceptor?" 


\section{LISTA DE ANEXOS}

Anexo A - Aprovação no Comitê de Ética da Faculdade de Medicina da Universidade de São Paulo .83

Anexo B - Autorização do IEP/HSL para coleta de dados...............................84

Anexo C - Questionário de Perfil Sociodemográfico........................................85

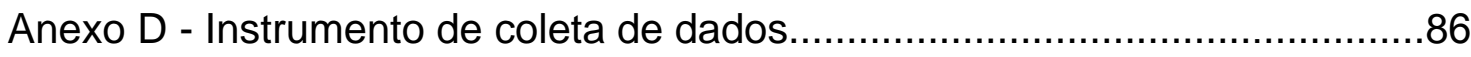

Anexo E - Termo de Consentimento Livre Esclarecido....................................89 
Resumo
Abstract 


\section{Resumo}

Girotto, LC. Preceptores do Sistema Único de Saúde: como percebem seu papel em processos educacionais na saúde [dissertação]. São Paulo: Faculdade de Medicina, Universidade de São Paulo; 2016.

INTRODUÇÃO: A preceptoria é uma modalidade de ensino em serviço, que forma profissionais em cenários de prática e que tem ocupado papel de destaque quando se discute a formação de profissionais de saúde. A preceptoria atende às Diretrizes Curriculares Nacionais para os cursos de graduação na saúde e ao princípio do Sistema Único de Saúde que preconiza a formação profissional no cenário de prática. Neste contexto, o preceptor, profissional que acompanha o aluno no cenário de prática, ensinando enquanto exerce suas atividades cotidianas, deve ser reconhecido como educador e estar formado de acordo com os princípios da andragogia. OBJETIVOS: Este estudo tem como objetivo analisar a percepção de preceptores do Sistema Único de Saúde sobre seu papel nos processos educacionais. MÉTODOS: Trata-se de um estudo exploratório transversal, de abordagem qualiquantitativa, com dados coletados em amostra de conveniência nas cinco regiões do Brasil. Foi construído e validado um instrumento de coleta de dados com 35 afirmações com respostas em escala do tipo Likert de cinco pontos, além de duas perguntas abertas. RESULTADOS: Fizeram parte do estudo 327 preceptores do Sistema Único de Saúde, com média de idade de 37,67 anos e maioria mulheres $(80,73 \%)$, enfermeiros $(35,17 \%)$ e profissionais que atuavam na assistência (64,51\%). Os participantes afirmaram que a preceptoria é uma 
atividade educacional em campo de prática, que utiliza métodos ativos de ensino-aprendizagem na formação de profissionais de saúde, sendo considerada como uma ponte entre o sistema de saúde e a academia. Apontaram que desempenham papel de modelo, tutor, orientador, supervisor e mentor ao desenvolverem suas atividades junto aos alunos. A análise de item demonstrou percepção negativa apenas no que dizia respeito à participação parcial da equipe e remuneração na preceptoria. A análise fatorial gerou cinco domínios principais: 1- Competência pedagógica, 2 - Suporte e recursos educacionais, 3 - Planejamento do programa educacional, 4 - Integração ensino-serviço e 5 - Presença do estudante no campo de prática. Os preceptores do nordeste tiveram a visão mais positiva acerca da preceptoria e suas vicissitudes, e os do sudeste a menos positiva. Entre as profissões, os preceptores farmacêuticos apresentaram a pior percepção. CONCLUSÃO: Os preceptores que participaram deste estudo demonstram clareza sobre a natureza da preceptoria e do seu papel de educadores, reconheceram que sua atividade junto aos alunos faz cumprir as diretrizes de formação profissional vigentes no Brasil.

Descritores: preceptoria; capacitação de recursos humanos em saúde; competência profissional; serviços de integração docente-assistencial; Sistema Único de Saúde 


\section{Abstract}

Girotto, LC. Preceptors of the Unified Public Health System: how they perceive their role on educational processes for healthcare professional [dissertation]. São Paulo: "Faculdade de Medicina, Universidade de São Paulo"; 2016.

INTRODUCTION: Preceptorship is a method of teaching out-of-field teaching which develop students using practical scenarios and is starting to have a important role in the healthcare professional training. Preceptorship attends the requirements of National Curricular Guidelines to healthcare graduation courses and the Unified Public Health System (SUS), which advocates the training of the professional on a practical scenario. In this context, the preceptor, a professional who guides the student on the practical scenario, teaching while developing the daily work routine, must be recognized as an educator and prepared following the principles of andragogy. AIMS: This study aims to analize the perception of the preceptors of the Unified Public Health System about their role on educational proccess. METHODS: This is a cross-sectional scoping study with both qualitative and quantitative approach, with data collected from a convenience sample from the five regions of Brasil. A questionnaire containing 35 statements with answers based on a Likert type scale and two open questions. FINDINGS: 327 preceptors from the Unified Public Health System participated in the study, with an average age of 37.67 years old and a majority of women $(80.73 \%)$, nurses $(35.17 \%)$ and professionals working on the assistance (64,51\%). The participants describes preceptorship as an educational activity in a practical field, which uses active 
learning methods of healthcare professionals training, being considered as a bridge between the Unified Public Health System and the university. They consider that they develop a role of model, tutor, leader, supervisor and menthor to the students. The analysis evences that there is a negative perception of the participation of the full professional team and that they get paid to be a preceptor. The fator analysis generated 5 domains: 1 . Pedagogical Competencies; 2. Support and educational resources, 3. Eduactional program planning; 4. Integration between teaching and health services and; 5. Attendance of the student on the practical field. Northeast preceptors had the most positive reaction about preceptorship and its vicissitudes, being southeast preceptors the one with the lowest positive one. Between professions, pharmacists showed the worst perception. CONCLUSION: Preceptors that participated the study demonstrated an adequate knowledge about the nature of preceptorship and their role as educators, recognizing that preceptorship fulfills the requirements of Brazilian's presente guidelines of professional training.

Descriptors: preceptorship; health human resource training; professional competence; teaching care integration services; Unified Health System 


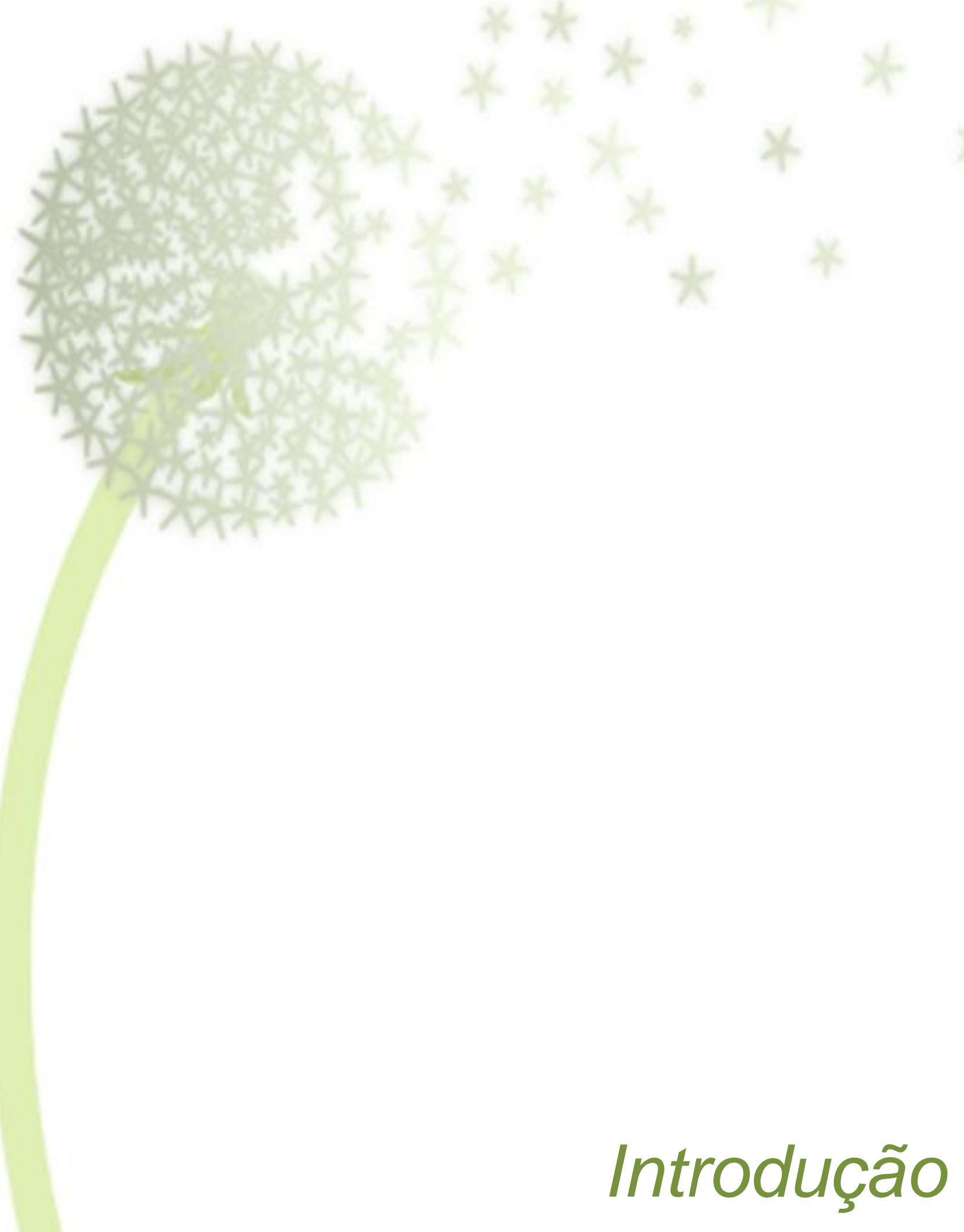




\section{Introdução}

No Brasil, as Diretrizes Curriculares Nacionais (DCN) defendem que a formação e o aperfeiçoamento de profissionais de saúde aconteçam nos diferentes níveis de atenção e cenários do Sistema Único de Saúde (SUS), preferencialmente na atenção primária. Esta proposta visa a formação de profissionais aptos para atuarem nestes cenários e atenderem as principais necessidades de saúde da população ${ }^{1,2}$.

O desafio que se coloca é diminuir o distanciamento entre o que se ensina nas universidades e as diferentes realidades de saúde, ou seja, uma maior articulação entre teoria e prática ${ }^{3}$. O modelo hegemônico de formação na saúde não favorece a visão integral da pessoa e do seu processo de adoecimento, com foco nas necessidades de saúde, no cuidado na atenção primária, na transformação das práticas profissionais e da realidade social ${ }^{4-11}$.

A ampliação dos cenários de aprendizagem e a valorização do ensino em serviço exigem mudança dos paradigmas admitidos na educação na saúde ${ }^{12,13}$. Por outro lado, a inserção de estudantes e profissionais em formação nos serviços de saúde pode, em muito, contribuir com aprimoramento da organização e da qualidade dos serviços ${ }^{14,15}$.

Neste contexto, o estudante será acompanhado pelo preceptor, um profissional do serviço de saúde, que assume perante ele funções educacionais. No entanto, esta relação de aprendizado nem sempre acontece nas melhores condições, pela ausência de capacitação pedagógica do preceptor e de legislação, pela inadequação dos espaços e do tempo disponível para desempenhar esta atividade, que concorre com as suas 
responsabilidades assistenciais. Além disto, a atividade de preceptoria se coloca como resposta às DCN, sem ter a devida valorização e correspondência no projeto pedagógico dos cursos de graduação e pós-graduação, e principalmente do currículo vivido.

\subsection{O Preceptor e a preceptoria}

A figura do preceptor é relatada desde a mitologia grega, na história de Asclépio ou Esculápio (518-438 aC), deus da cura, que nasceu da relação entre o deus-sol Apolo com uma mortal, que foi assassinada por ordem dele após ter cometido adultério. Asclépio foi retirado do ventre de sua mãe morta e entregue ao preceptor Quíron, um centauro que dominava a arte da cura e autoconhecimento, e ficou responsável por sua criação e educação. Como preceptor e educador, Quíron auxiliou Asclépio no desenvolvimento de suas potencialidades e foi superado por ele na arte de $\operatorname{curar}^{16}$.

No campo da saúde, o termo preceptor foi utilizado incialmente na literatura nacional e internacional em programas de residência médica, no entanto passou a ser utilizado também para a formação de profissionais de outras áreas da saúde, na graduação e pós-graduação ${ }^{17}$, sendo que a enfermagem é a profissão com maior número de trabalhos publicados envolvendo a figura do preceptor e a preceptoria.

O preceptor é um profissional que atua no serviço de saúde, com formação generalista ou de especialista, cuja função se caracteriza pelo acompanhamento direto e orientação quanto às atividades práticas realizadas por estudantes de graduação e pós-graduação, enquanto desenvolve sua 
função assistencial ${ }^{14,18-25}$. Trata-se de uma estreita relação de ensinoaprendizagem 1:1 ou one-by-one, na qual o preceptor atua como modelo para o profissional em formação, buscando apoiar a inserção deste profissional no mundo do trabalho e auxiliar na aquisição de conhecimento, habilidades e atitudes necessários à prática ${ }^{26-28}$. Pode-se dizer que o preceptor assume 0 papel de role mode ${ }^{29}$, ou seja, um profissional que inspira e estimula desenvolvimento dos demais.

Em consulta aos Descritores em Ciências da Saúde (DeCS), a preceptoria (preceptorship) encontra-se na categoria Antropologia - Educação, Sociologia e Fenômenos Sociais - Educação e tem a seguinte definição em português: "Experiência prática em medicina e serviços relacionados à saúde que ocorre como parte de um programa educacional no qual o estudante em treinamento profissional trabalha fora do ambiente acadêmico sob supervisão de um profissional estabelecido no campo específico".

Trabalhos publicados internacionalmente definem preceptoria como a atividade de ensino-aprendizagem desenvolvida pelo preceptor visando a preparação para a prática profissional, com foco no desenvolvimento clínico e ético, ao mesmo tempo, esta atividade educacional apresenta ao estudante a realidade do serviço de saúde, equipes e comunidades $^{30,31}$. Desta forma, a preceptoria ocorre no horário e local de trabalho, concomitantemente às atividades assistenciais do preceptor e da equipe de saúde ${ }^{31}$.

Em alguns momentos, nota-se "confusão" entre os termos preceptoria, tutoria e mentoring. A preceptoria, como já especificado anteriormente, trata-se de uma relação mais intensa e menos duradoura, enquanto o mentoring é definido com um processo entre um profissional mais experiente - o mentor, e 
um profissional menos experiente, que visa o desenvolvimento pessoal e profissional, mediante uma relação de longa duração, alto nível de comprometimento e fora dos horários de assistência ${ }^{19,32}$. O acompanhamento dos alunos para o aprendizado junto ao paciente, denominado por Dent como ward-based learning ou bedside learning (ensino na enfermaria, ou à beira do leito), pode ser feito por residentes, profissionais, ou por outros alunos em formação, por meio do aprendizado em pares, e é denominado tutoria ${ }^{33}$.

Apesar de apoiar-se em diferentes termos e papeis, pode-se afirmar que o preceptor representa um potente elo entre a instituição de ensino e o serviço de saúde ${ }^{34}$ enfatizando a indissociabilidade entre teoria e prática, já que ambas são essenciais para a reflexão e pensamento crítico, conduzindo a uma visão holística do cuidado ${ }^{30}$.

A formação profissional na saúde é um processo de educação de adultos, que exige dos preceptores, além dos conhecimentos relativos à sua área de atuação, conhecimentos dos princípios da andragogia, habilidades pedagógicas e relacionais ${ }^{14,35,36}$. Sem estes princípios os preceptores podem não compreender como sua atuação junto aos estudantes influencia a formação profissional ${ }^{33}$.

Em alguns países como Reino Unido e Austrália, as atividades de ensino são consideradas como parte do papel dos profissionais de enfermagem durante o exercício de suas atividades práticas ${ }^{31}$. No entanto, não é exigido que os preceptores tenham uma formação específica em educação para desempenhar esta atividade, o que significa uma barreira ao reconhecimento do preceptor na educação dos estudantes ${ }^{27}$. 
Em revisão de literatura sobre o tema, Billay e Myrick apontam que as dificuldades encontradas pela preceptoria no decorrer dos anos parecem ser as mesmas e fazem algumas constatações: a preceptoria continua sendo entendida e praticada como um método comum de ensino-aprendizagem; há necessidade de parceria entre ensino e serviço; conhecimento e experiência do preceptor são os maiores ativadores da aprendizagem; o currículo deve ser bem pensado, conforme prática clínica e existem atributos do preceptor que otimizam o aprendizado ${ }^{37}$.

A preceptoria envolve principalmente três atores: preceptor, aluno e academia. O preceptor tem o papel de ser modelo e de garantir o ambiente de aprendizagem ao aluno, que por sua vez assume o papel ativo em sua aprendizagem, buscando se tornar um bom profissional. A academia tem o papel de dar suporte ao aprendizado do aluno e à atividade de ensino do preceptor. O papel de cada um dos atores e o plano de ensino devem estar bem planejados e pactuados, de maneira a proporcionar melhores resultados $^{37,38}$. A falta de comunicação da universidade com os profissionais do serviço que atuam como preceptores causa desconfortos e pode comprometer a inserção dos estudantes no serviço e a aceitação por parte da equipe ${ }^{28}$.

No Brasil, a atividade de preceptoria surgiu antes da oferta de cursos de especialização em educação na saúde para preceptores. A maioria dos preceptores iniciou suas atividades sem receber capacitação adequada na área da educação, na qual acabam por destinar grande parte de sua carga horária ${ }^{34,39,40}$.

Embora o SUS tenha como compromisso formar recursos humanos ${ }^{41} \mathrm{e}$ as DCN, desde 2001, apontem para o aprendizado em prática, a preceptoria 
nem sempre recebe valorização e incentivo para que os profissionais desenvolvam esta função, com referência não apenas à remuneração, mas também ao apoio de gestores, instituições, capacitação e infraestrutura ${ }^{34}$. A partir de 2004, surgiram regulamentações para o exercício da preceptoria na residência médica e multiprofissional e em 2012, por meio da Lei n 12.871 , a formação em serviço e a atividade de preceptoria foram normatizadas para a graduação em medicina $^{42-44}$.

Tendo em vista que se trata de uma normatização recente, ainda é comum a falta de apoio institucional, a ausência de capacitação didáticopedagógica e a sobrecarga de trabalho pela dupla função; muitos profissionais se tornam preceptores de forma voluntária, pela ideologia de participar da formação profissional ${ }^{45}$.

\subsection{A educação em serviço}

A educação em serviço surge com a necessidade de inserir o componente prático à formação. Os aprendizes, enquanto são acompanhados por um profissional mais experiente, associam teoria e prática, e desenvolvem as competências necessárias ao exercício profissional ${ }^{17}$.

A formação atrelada ao fazer na prática profissional teve início no período pré-hiprocrático, descrita no mito grego do preceptor Quíron e seu discípulo Asclépio (518-438 aC). Este mito influenciou Hipócrates (460-377 $\mathrm{aC)}$, que dedicava-se à educação e ao processo ensino-aprendizagem da 
medicina enquanto ensinava pequenos grupos de discípulos sob árvores no centro da cidade, junto à comunidade e aos enfermos ${ }^{46}$.

Na Idade Média, predominava a formação de práticos, ou seja, o modelo de ensino e formação profissional era aquele em que o aprendiz acompanhava o trabalho de um profissional mais experiente em seu dia a dia, até o momento em que fosse considerado apto para desempenhar a função ${ }^{47}$. Este método foi paulatinamente sendo abandonado a partir do século XX, quando a ênfase da formação foi deslocada para as bases científicas e o ensino ficou sediado nas escolas médicas e em hospitais. Atualmente, acompanhar um médico experiente é chamado por alguns autores de shadow, já que o aluno ou residente vira a sombra de um professor para aprender com ele na prática cotidiana ${ }^{48}$.

No Brasil, os cursos superiores tiveram início em 1808, com a chegada da Família Real portuguesa, quando D. João VI criou a primeira escola médica, em Salvador. Após 104 anos foi fundada a segunda escola médica brasileira na Universidade do Estado de São Paulo, já com bases científicas de acordo com a as ideias dispostas no Relatório Flexner ${ }^{49}$.

Em 1910, diante do crescimento desenfreado das escolas médicas norte-americanas, foi publicado nos Estados Unidos, o Relatório Flexner, resultado da avaliação dos cursos de medicina nos Estados Unidos e Canadá, que possibilitou rever a qualidade das escolas de medicina com base em conhecimentos científicos. Este relatório foi determinante para muitos avanços científicos na área médica, no entanto o ensino proposto por Flexner resultou também em um aprendizado da medicina centrado na doença e no ambiente 
hospitalar, denominado "modelo flexneriano", o qual influenciou o ensino das demais profissões da área da saúde em todo o mundo ${ }^{50}$.

Na mesma época, no Reino Unido, foi publicado o Informe Dawson (1920), com a intenção de estabelecer uma rede de serviços regionalizada e hierarquizada entre os setores primário (generalista), secundário (especialista) e terciário (hospital) de cuidado à saúde, prevendo a formação profissional nestes espaços. Além desta rede, com equipamentos de saúde de diferentes densidades tecnológicas, este documento propunha a integração entre ações curativas e preventivas e atuação de equipes multiprofissionais no cuidado, preconizando, inclusive, o atendimento domiciliar ${ }^{51,52}$.

Diversas iniciativas nacionais e internacionais norteiam o ensino em serviço e afirmam a necessidade de mudança na lógica da formação em saúde. Algumas delas serão brevemente discutidas a seguir, como: Reforma Universitária Brasileira (1968), Reforma Sanitária Brasileira (1970), Relatório Lalonde (1974), Conferência de Alma-Ata (1978), Constituição Federal Brasileira (1988), Conferência de Edimburgo (1988), Lei Orgânica da Saúde (1990), Projetos IDA e UNI (1990), CINAEM (1991), IX Conferência Nacional de Saúde do Brasil (1992), DCN para os Cursos de Graduação na Área da Saúde (2001 a 2004), Promed (2002), AprenderSUS (2004), Pró-Saúde (2005), PROVAB (2011) e Novas DCN para os Cursos de Medicina e Lei do Mais Médicos para o Brasil (2013).

A partir da década de 1950, houve grande incentivo da Organização Pan-Americana de Saúde (OPAS) para que as escolas criassem seus Departamentos de Medicina Preventiva, incentivando assim uma formação 
mais focada nas necessidades de saúde da população, na qualidade dos serviços e na transformação da educação dos profissionais, pressupondo uma integração do ensino com os sistemas de saúde ${ }^{47}$.

A Reforma Universitária Brasileira, expressa na Lei nํ⒌540, de 28 de novembro de 1968, deu início a um movimento de organização na educação dos profissionais de saúde, sem, no entanto, integrar disciplinas, mantendo um modelo compartimentado de ensino ${ }^{47,53}$.

Também no Brasil, a partir do final da década de 1970, iniciou-se um processo de transformações marcantes em busca da melhoria das condições de saúde da população, denominado Reforma Sanitária. Ele acompanhava ideias de cuidado integral à saúde, assumidas também por coletivos de profissionais da saúde, da educação, sanitaristas e pensadores internacionais, que defendiam a transição do modelo unicausal para o modelo da multicausalidade no processo de saúde e doença.

Este modelo foi evidenciado no Relatório Lalonde (1974), no Canadá, que defendia a multicausalidade na saúde e na doença e a influência dos determinantes sociais, políticos e econômicos ${ }^{54}$. Quando assumido este modelo, o ensino na saúde passa a ter que considerar aspectos mais amplos do processo de adoecimento, considerando a integralidade e singularidade dos sujeitos ${ }^{50}$.

As ideias contidas no Relatório Lalonde foram reforçadas na Conferência Internacional da Organização Mundial da Saúde (OMS), em 1978, em AlmaAta. Este encontro teve como tema "Saúde para todos no ano 2000", que seria alcançada se os processos de cuidado tivessem como foco a atenção 
primária $^{55,56}$. As propostas da Conferência de Alma-Ata influenciaram significativamente a maneira como se construiu o SUS no Brasil ${ }^{50}$.

Este contexto de revisão do modelo de cuidado à saúde estimulou novas formas de pensar o ensino na saúde, como a Rede de Integração dos Projetos Docente-Assistenciais - IDA, definidos pela OPAS a partir de 1979, que propunha a construção de uma "rede-escola", com articulação ensino-serviço visando uma adequação do sistema de saúde às necessidades de saúde da população, produção de conhecimentos e formação em cenários de prática ${ }^{57}$. Nesta iniciativa, o serviço passou a ser considerado como espaço potente de produção de conhecimentos. A Rede IDA integrava serviços de diferentes densidades tecnológicas de maneira a garantir a integralidade do cuidado à população e constituir espaços de aprendizagem para os estudantes de graduação e pós-graduação ${ }^{47,58}$, evidenciando a necessidade de mudança no modelo de ensino dos profissionais de saúde e a importância de integrar estes estudantes à equipe de saúde, o que exigiria uma superação do modelo flexneriano ${ }^{57}$.

No ano de 1988 ocorreu a Conferência Mundial de Educação Médica, promovida pela World Federation for Medical Education (WFME), OMS e United Nations Children's Fund (UNICEF), que resultou na publicação da Declaração de Edimburgo, documento cujos princípios norteiam o ensino na saúde até os dias atuais. Foram ressaltados pontos como prioridades e estratégias educacionais, articulação ensino-serviço, compromisso social da escola médica de formar profissionais que irão promover a saúde das pessoas. A declaração teve como princípios: ampliar os cenários de ensino- 
aprendizagem para além dos hospitais, garantir que o conteúdo curricular contemple as prioridades de saúde e os recursos existentes no serviço de saúde vigente, garantir que o processo ensino-aprendizagem apoie 0 desenvolvimento de competência profissional e valores sociais e não apenas a retenção de informações, ensino do cuidado centrado no paciente, com ênfase na prevenção de doenças e promoção da saúde, garantir que as escolas médicas contemplem a avaliação de qualidades pessoais e não apenas capacidade intelectual $^{50,51,57}$.

Com influência dos movimentos que estavam ocorrendo no Brasil e no mundo, as propostas da Reforma Sanitária resultaram na universalidade do direito à saúde, oficializado com a Constituição Federal Brasileira, promulgada em 5 de outubro de 1988, e a criação do SUS. Em seu Capítulo II, a Constituição traz que "A saúde é um direito de todos e dever do Estado"59. Com a garantia dos princípios de integralidade, universalidade e equidade, o SUS foi regulamentado, por meio da Lei Orgânica da Saúde - Lei Federal nº 8.080, de 19 de setembro de 1990. No seu Capítulo I, que trata dos objetivos e atribuições do SUS, está contemplada "a ordenação da formação de recursos humanos na área de saúde" 41 .

Após uma análise crítica dos Programas IDA, surgem, na década de 1990, os Projetos UNI - Uma Nova Iniciativa na Educação dos Profissionais de Saúde: união com a comunidade. Amplia-se, então, a discussão acerca da formação na saúde incluindo a participação popular no processo de revisão dos projetos curriculares, propondo a integração ensino-serviço-comunidade e a criação de redes locais de saúde. Estes projetos propunham como pontos 
importantes a epidemiologia, interdisciplinaridade, multiprofissionalidade e ensino em serviço ${ }^{57}$.

Os Projetos UNI (articulação ensino-serviço-comunidade) e Rede IDA (integração docente-assistencial) passaram a integrar a Rede Unida, com a proposta de reformulação do modelo de educação dos profissionais de saúde com valorização do trabalho multiprofissional e da interação entre o ambiente de ensino e os espaços de trabalho em saúde ${ }^{57}$.

Neste mesmo período, onde o movimento de reflexão sobre a formação dos profissionais de saúde era intenso, foi criada a Comissão Interinstitucional de Avaliação do Ensino Médico - CINAEM (1991), que contou com participação de profissionais e estudantes representados nos seguintes órgãos: Academia Nacional de Medicina, Associação Brasileira de Educação Médica, Associação Médica Brasileira, ANDES - Sindicato Nacional dos Docentes das Instituições de Ensino Superior, Associação Nacional dos Médicos Residentes, Conselho Federal de Medicina, Conselho dos Reitores das Universidades Brasileiras, Conselhos Regionais de Medicina de São Paulo e Rio de Janeiro, Direção Executiva Nacional dos Estudantes de Medicina e Federação Nacional dos Médicos.

O objetivo da CINAEM era a avaliação do ensino médico, contemplando nesta avaliação os recursos humanos, movimentos pedagógicos e a qualidade da formação médica, explicitando a realidade destas escolas e a sua situação real. A conclusão foi a necessidade de reformular o ensino da medicina no país, baseado em tudo o que se vinha discutindo sobre saúde e ensino e a necessidade de mudança dos modelos para ambos, saúde e ensino ${ }^{50}$. 
Neste contexto e diante da avaliação da CINAEM, foram elaboradas e homologadas por meio da resolução CNES/CES $n^{\circ} 4$, de 07 de novembro de 2001, as DCN dos Cursos de Graduação em Medicina, que propunham a formação de um profissional crítico-reflexivo, voltado aos diferentes níveis de atenção, com ações de promoção, prevenção, recuperação e reabilitação à saúde. Para esta formação, voltada às necessidades de saúde da população e com ênfase no SUS, a resolução preconiza a utilização de diferentes cenários de ensino-aprendizagem, que proporcionem vivências variadas, por meio da articulação ensino-serviço ${ }^{1}$.

Em sequência, foram publicadas, entre os anos de 2001 e 2004, as DCN para os cursos de graduação em saúde: educação física, enfermagem, farmácia, fisioterapia, fonoaudiologia, medicina, nutrição, odontologia, saúde coletiva e terapia ocupacional ${ }^{47}$. As $\mathrm{DCN}$ para os cursos de graduação na saúde norteiam a formação em cenários de prática da atenção primária e reforçam as atividades de preceptoria e trazem as mesmas competências gerais esperadas dos profissionais em formação, sendo a atenção à saúde, comunicação, tomada de decisões, administração e gerenciamento, liderança e educação permanente.

Em 2002, os Ministério da Saúde e da Educação lançaram o Programa de Incentivo à Mudanças Curriculares nos Cursos de Graduação em Medicina - PROMED, cujo intuito era identificar projetos potentes de implementação das DCN, com propostas de adequação curricular para formação de profissionais voltada ao SUS, para incentivo financeiro ${ }^{60}$.

Em 2003, após uma revisão e avaliação da primeira publicação das recomendações para formação de profissionais médicos no Reino Unido 
(1993), o General Medical Council, publicou uma nova versão, onde constavam conhecimentos, habilidades, atitudes e comportamentos esperados dos profissionais egressos da graduação. Este documento, dentre outros pontos, trouxe a necessidade de um curso de graduação ofertar experiências em cenários de prática variados, oportunidades de aprendizagem que levem o estudante ao desenvolvimento da criticidade e estimulem o aprendizado autônomo e a importância de os egressos entenderem a lógica do sistema de saúde vigente no país ${ }^{11}$.

Em 2004 foi criada, no Brasil, uma política do SUS que tratava do ensino de graduação nas profissões da área da saúde, o AprenderSUS. Esta política discorre sobre a implementação das DCN nos cursos de graduação, orientação dos profissionais em formação para uma visão sobre a integralidade do cuidado, investimento em mudanças neste modelo de formação e "Vivência e Estágio na Realidade do SUS" - VER-SUS ${ }^{61}$.

No ano de 2005, a Education Committee Of The General Medical Council Health Organization (WHO) e a WFME, com o propósito de melhorar a qualidade do ensino e do cuidado à saúde, publicaram as Diretrizes para Acreditação do Ensino Médico, consideradas globais, mas flexíveis, já que foram reconhecidas as diferenças entre a organização do ensino e dos serviços de saúde em cada país ${ }^{62}$.

O Programa Nacional de Reorientação da Formação Profissional em Saúde - Pró-Saúde (2005), também seguia a lógica de apoiar transformações na formação, com foco na integralidade ${ }^{63}$, porém, sofreu diversas críticas por ser voltado apenas aos cursos de medicina, enfermagem e odontologia ${ }^{47}$. 
Ainda no sentido de direcionar os profissionais em formação para os espaços estratégicos do SUS, pode-se ressaltar a criação do Programa de Valorização dos Profissionais da Atenção Básica - PROVAB (2011), que tem por objetivo a valorização, aperfeiçoamento e educação permanente dos profissionais que atuam na atenção básica.

No ano de 2013, foi publicada a Medida Provisória nº 612/2013, convertida na Lei $n^{\circ} 12.871$, de 22 de outubro de 2013, que institui o Programa "Mais Médicos", com o intuito de suprir a necessidade de profissionais médicos em determinadas áreas do país e propõe como meta a criação de 11,5 mil vagas nos cursos de medicina até 2017 e 1086 vagas para residência multiprofissional e de especialidades. Este programa visa formar recursos humanos na área médica para o SUS, para suprir a carência de médicos em dadas regiões do país, fortalecer a atenção básica e a inserção dos profissionais em cenários do SUS, dentre outros pontos ${ }^{44,64}$.

No ano de 2014, por meio da Resolução nํㅜ 3, de 20 de junho de 2014, foram homologadas as novas DCN para os cursos de graduação em Medicina, propondo uma formação pautada na articulação entre conhecimentos, habilidades e atitudes e focada nas áreas de atenção, gestão e educação em saúde ${ }^{10}$.

Desde 2006, os Congressos Brasileiros de Educação Médica têm mantido o foco na discussão de assuntos relacionados às necessidades de mudança na educação dos profissionais, buscando atender ao proposto nas DCN. 
Neste cenário, que exige equilíbrio entre o real e o ideal, o papel do preceptor favorece o aprendizado de relações no contexto do cuidado mais humanizadas, além de promover o posicionamento crítico-reflexivo, resultando no amadurecimento ético-profissional, através da observação de práticas cotidianas $^{18,20}$.

O ensino em serviço vem permeando as iniciativas que discutem a formação dos profissionais de saúde e o diálogo entre academia e serviços, uma vez que a inserção destes profissionais nos cenários de produção do cuidado é a garantia de uma formação voltada à realidade dos serviços e às necessidades de saúde da comunidade, conforme contextos sociais.

Para uma melhor compreensão da cronologia dos fatos considerados como marcantes para a educação em serviço, observe a Figura 1.

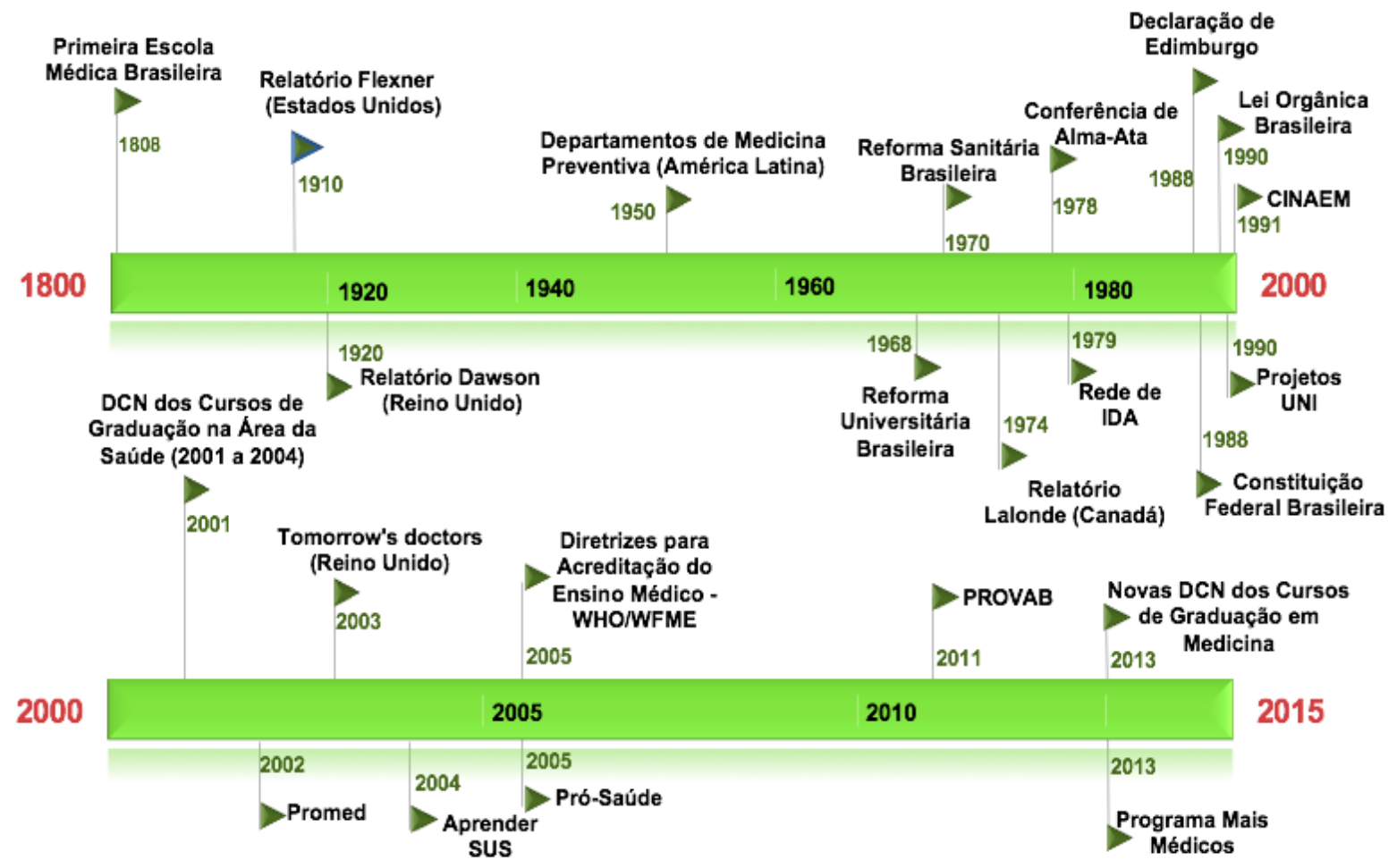

Figura 1 - Linha do tempo da educação em serviço 


\subsection{A educação de adultos}

A aprendizagem pode ser definida como uma mudança no potencial de comportamento, que ocorre após a aquisição de informações e experimentações. Pode ser que após uma dada experiência, a mudança de comportamento não seja notada imediatamente, apenas quando houver oportunidade de demonstração do conhecimento adquirido, portanto, diz-se que a aprendizagem promove aquisição de capacidade, sem que necessariamente o desempenho seja explicitado ${ }^{65,66}$.

A busca pela aquisição de conhecimento aplicável pode ser observada desde a pré-história, quando o homem aprendia através do relacionamento com a natureza e esta aprendizagem visava basicamente a proteção da vida. $\mathrm{Na}$ Idade Antiga, no ocidente, o conceito de escola surge com a Academia de Platão, em Atenas. Neste tempo, a aprendizagem visava a formação dos indivíduos para a vida em sociedade, não mais apenas com foco na sobrevivência, mas também na harmonia das relações. Os objetivos e a estruturação das escolas foram se modificando através do tempo, de tal forma que, na Idade Média, a Escola Clássica Europeia era privilégio da elite. Neste período, o ensino, focado no saber religioso e realizado em mosteiros, por professores considerados os detentores do saber, tinha pouca aplicabilidade ${ }^{66}$.

Na Escola Jesuítica da Idade Moderna, o processo de ensino seguia um manual chamado Ratio Stvdiorvm, que descrevia como deveria ser o ensino, sendo este baseado na aula, exercícios para memorização e prova para avaliação do aprendizado $^{67}$. No entanto, este modelo de ensino não era consenso. Jan Amos Comenius (1627) desenvolveu o conceito de Escola 
Instrucional, introduzindo o método e a sistematização pedagógica, baseados em planos de ensino e materiais didáticos e uma formação norteada pelo desenvolvimento de perfeição, moral e sabedoria. Tendo em vista a dimensão da sua obra Didatica Magna, Comenius passou a ser considerado o "Pai da Didática Moderna"68-70.

Na Idade Contemporânea, no contexto da Revolução Industrial, o ensino passou a ser em grande escala e focado na profissionalização, visando sustentar o interesse econômico vigente. Neste período, o ensino foi fragmentado em disciplinas, pois se entendia que conhecer o todo não era 0 importante, mas sim a especialização em uma tarefa proposta ao indivíduo ${ }^{66}$.

No século $\mathrm{XX}$, houve um grande progresso no entendimento do processo de aprendizado, tanto de crianças quanto de adultos. $\mathrm{O}$ ensino, que se baseava no modelo jesuítico e profissionalizante, passa a ser questionado e tem início uma busca por novos métodos e tecnologias de ensino. O processo de ensino-aprendizagem passa a focar o aluno, que deixa de ser considerado um receptor passivo de informações, enquanto o professor não se coloca mais como o único detentor do saber. O contexto e a aplicabilidade do conhecimento são valorizados, fazendo com que o ensino extrapole os muros da escola e busque outros cenários, capazes de aproximar o aprendiz da realidade. A busca pela contextualização preconiza, também, a inter-relação entre as disciplinas e a integração dos seus conteúdos. Este processo de inovação do ensino, que teve início no final do século $X X$, ampliou-se no século $X X I$, com a popularização das ferramentas digitais de informação e comunicação ${ }^{65}$.

É neste contexto histórico, cultural e estético que se desenvolveram diferentes teorias de aprendizado e modelos de educação de adultos, que 
levassem em consideração as experiências acumuladas ao longo da vida e a capacidade do adulto de aprender com seus erros. Na década de 1926, Linderman já buscava métodos adequados para ensinar adultos, que foram retomados em 1970 por Malcolm Knowles, psicólogo americano, que elaborou os princípios da educação de adultos, aos quais denominou andragogia (andros = adulto e gogos= educar), "a arte e ciência de ajudar adultos a aprender" ${ }^{71}$.

$\mathrm{Na}$ andragogia, o professor atua como mediador do aprendizado e considera o aprendiz como centro do processo, ao buscar compreender suas necessidades de aprendizagem e seus conhecimentos prévios. Este professor desempenha o importante papel de demonstrar ao aprendiz a aplicabilidade do que deve ser aprendido ${ }^{71}$. Este processo de compreender a aplicabilidade do conhecimento por meio da mobilização e ressignificação do conhecimento prévio, é definido por David Ausubel como aprendizagem significativa. A construção do significado da aprendizagem se dá por reconstruções sucessivas do conhecimento acumulado, por meio de investigação individual ou por colaboração em grupo ${ }^{65}$.

A concepção do processo ensino-aprendizagem na andragogia prioriza a prática em detrimento da teoria e propõe um espaço de aprendizado aberto às iniciativas dos alunos, no qual a aprendizagem se dá a partir da interação entre aprendizes e educadores e os objetos de estudo definidos por ambos, proporcionando a construção de conhecimentos de forma dialógica e dialética $^{35,67}$. A defesa da prática sobre a teoria parte do princípio de que as vivências sucessivas permitem diferentes visões sobre a informação adquirida e que isso proporciona diferentes maneiras de interagir com a realidade 
encontrada, portanto, o conhecimento não é estático e sim adaptável às diferentes reações do indivíduo frente ao mundo ${ }^{65}$.

Existem muitos modelos teóricos que explicam o processo de aprendizagem. Neste item, serão abordados alguns deles, pois o foco não é esgotar o tema, mas contribuir para o entendimento dos possíveis resultados desta pesquisa.

O modelo teórico inatista, também chamado apriorista ou nativista, pressupõe que o indivíduo traz consigo suas características desde o nascimento, dependendo apenas do momento em que irá ocorrer o amadurecimento para se revelarem. Neste modelo, entende-se que a educação, o professor e a interação com o meio muito pouco interferem no desenvolvimento do indivíduo ${ }^{36}$.

O modelo tradicional considera o aluno um receptáculo de informações, que são transmitidas por um professor, considerado detentor do saber e cuja formação é dada como finalizada. As metodologias baseadas no modelo tradicional de aprendizagem preconizam a repetição para memorização, seguida de avaliação como maneira de comprovar que a apreensão das informações de fato ocorreu. Neste modelo existe uma clara hierarquia entre aluno e professor.

Educadores e psicólogos desenvolveram o modelo de aprendizagem comportamentalista ou behaviorista, que defende a ideia de que o aprendizado é determinado pelo comportamento, que quando reforçado é assimilado.

A hierarquia presente no modelo tradicional passou a ser questionada pelo modelo de aprendizagem humanista, com foco na vivência do aprendiz e no desenvolvimento de sua personalidade, tendo o professor como apoiador. 
Este modelo de aprendizagem ficou muito popular a partir das experiências da Escola Summerhill, na Inglaterra e da Escola da Ponte, em Portugal.

O modelo teórico interacionista recebe esta denominação pela interação pressuposta entre o sujeito e o objeto de estudo. Alguns autores subdividem este modelo em cognitivista-construtivista e sócio-construtivista. No primeiro, a interação se dá predominantemente de forma vertical, entre o sujeito e o objeto de estudo e no segundo, ocorre de modo horizontal entre o sujeito, o objeto de estudo e seu meio social, que pode ser representado pelo grupo de aprendizagem, equipe de trabalho e pelo professor como mediador deste processo.

O modelo cognitivista-construtivista, defendido por Piaget, supõe que há um mecanismo biológico de concepção do conhecimento (conhecimento científico), denominado auto regulação e que é ativado pela interação do sujeito com o meio e que irá promover equilíbrio das estruturas cognitivas. Então, o desenvolvimento intelectual pleno ocorreria por assimilação e preenchimento de lacunas cognitivas, independente do contexto sociocultural. Para Piaget, o conhecimento é constituído biologicamente, podendo-se dizer que a capacidade intelectual é hereditária, dependendo apenas das fases vividas pelo sujeito para que seja desenvolvida, não sofrendo influências político-ideológicas ou socioculturais da história do homem ${ }^{72}$.

O modelo teórico sócio-construtivista, também chamado de Aprendizagem Social, por outro lado, afirma que a construção do conhecimento se dá por meio da relação entre quem aprende, quem ensina e o objeto de aprendizagem que é escolhido dentro de uma realidade compartilhada por ambos. Este modelo não coloca o aprendiz como o único responsável pelo seu 
aprendizado, mas afirma que este deve participar ativamente da construção de seu próprio conhecimento de maneira autônoma, enquanto é capaz de receber informações, buscar outras, aliar tais informações aos seus conhecimentos prévios e interpretá-las com criticidade ${ }^{35,66}$.

Ao propor a teoria sócio-construtivista, Vygotsky considerou principalmente o aprendizado de crianças, mas suas ideias podem ser perfeitamente aplicadas à maneira como os adultos aprendem. Esta teoria explica que há uma zona de desenvolvimento proximal, considerada como o espaço, ou a distância entre algo que o indivíduo é capaz de realizar sozinho (nível de desenvolvimento real ou efetivo) e aquilo que ainda precisa de mediação de outro indivíduo mais experiente para ser capaz de desenvolver (nível de desenvolvimento potencial). Este conceito de zona de desenvolvimento proximal ajuda na compreensão de como se dá a relação entre ensino, aprendizagem e desenvolvimento humano ${ }^{36}$.

O sócio-construtivismo traz a figura do professor, como mediador do processo de aprendizagem, que auxilia na transposição desta zona de desenvolvimento proximal. Os educadores assumem o papel de auxiliar os estudantes a desenvolver habilidades e formular questões significativas ao seu aprendizado, priorizando a construção de um saber aplicável, sem desconsiderar os conhecimentos que estes estudantes trazem consigo, acumulados ao longo de sua trajetória pessoal e profissional. Estes educadores devem ser capazes de identificar possíveis lacunas nestes conhecimentos prévios do educando, de maneira a auxiliá-lo na desconstrução das crenças equivocadas e construção de um conhecimento mais maduro, ou melhor dizendo, na adequação das crenças iniciais às científicas, de maneira que se 
desenvolva a consciência crítica ${ }^{73}$. Nesta teoria, as relações entre os sujeitos e as diferentes maneiras de agir e pensar são pontos valorizados e entendidos como potentes na produção de novos conhecimentos ${ }^{36}$.

Como exemplo do sócio-construtivismo, tem-se a Pedagogia Progressista, desenvolvida por Paulo Freire, que afirma que a educação de adultos é um processo cognitivo, político, ético, histórico, cultural e social que se dá por meio da relação dialética e dialógica entre quem ensina e quem aprende e transforma ambos, porque quem forma, ao formar se re-forma. Cognitivo, por depender do desejo individual de busca pelo conhecimento, político, pois afirma que não é possível ser completamente imparcial ao ensinar, já que quem educa tende a defender aquilo em que acredita, mas ao mesmo tempo ético, por respeitar a singularidade de cada um e histórico, já que considera uma realidade e cultura na qual os sujeitos estão inseridos. Trata-se de um processo dialógico porque parte do diálogo entre aquele que aprende e aquele que ensina e dialético porque, a partir do diálogo, formam-se novas e sucessivas sínteses com potencial transformador da realidade de $\operatorname{ambos}^{35,66}$.

Bransford et al. defendem que, independente do modelo teórico de aprendizagem de adultos, a pessoa que aprendeu, compreende os fatos e conceitos e é capaz de aplicar este conhecimento nos mais diversos contextos e não apenas memorizá-lo. Neste sentido, alguns modelos são mais indicados que outros ou se complementam para isto, sendo o aprendizado na prática uma estratégia preferencial ${ }^{73}$.

A preceptoria é uma atividade docente, que acontece em cenário de prática e exige capacitação relativa aos princípios que norteiam o processo 
ensino-aprendizagem. Um bom desempenho profissional por parte do preceptor não garante um bom desempenho docente, ou seja, o fato de ter habilidades práticas, não garante que um profissional tenha a habilidade necessária para ensinar outros profissionais sobre como desempenhar a mesma prática. Saber ensinar exige que se saiba o que, como e a quem ensinar ${ }^{66}$.

Este formato de aprendizagem na prática, mediado por um preceptor, é favorável ao desenvolvimento de uma consciência crítica pelo estudante acerca da realidade. Espera-se que neste espaço de prática os profissionais que estão sendo formados sejam capazes de identificar e resolver problemas à medida que forem surgindo, ou seja, que desenvolvam competência adaptativa: capacidade de flexibilizar o conhecimento adquirido de acordo com os problemas encontrados e aprender constantemente ao longo da vida, com aperfeiçoamento contínuo ${ }^{73,74}$.

Quanto melhor preparado for o preceptor que recebe o estudante em prática, maior será a chance de alcançar este e outros objetivos educacionais, bem como a mudança de perfil profissional desejado nas DCN para fortalecimento e aprimoramento do SUS. 


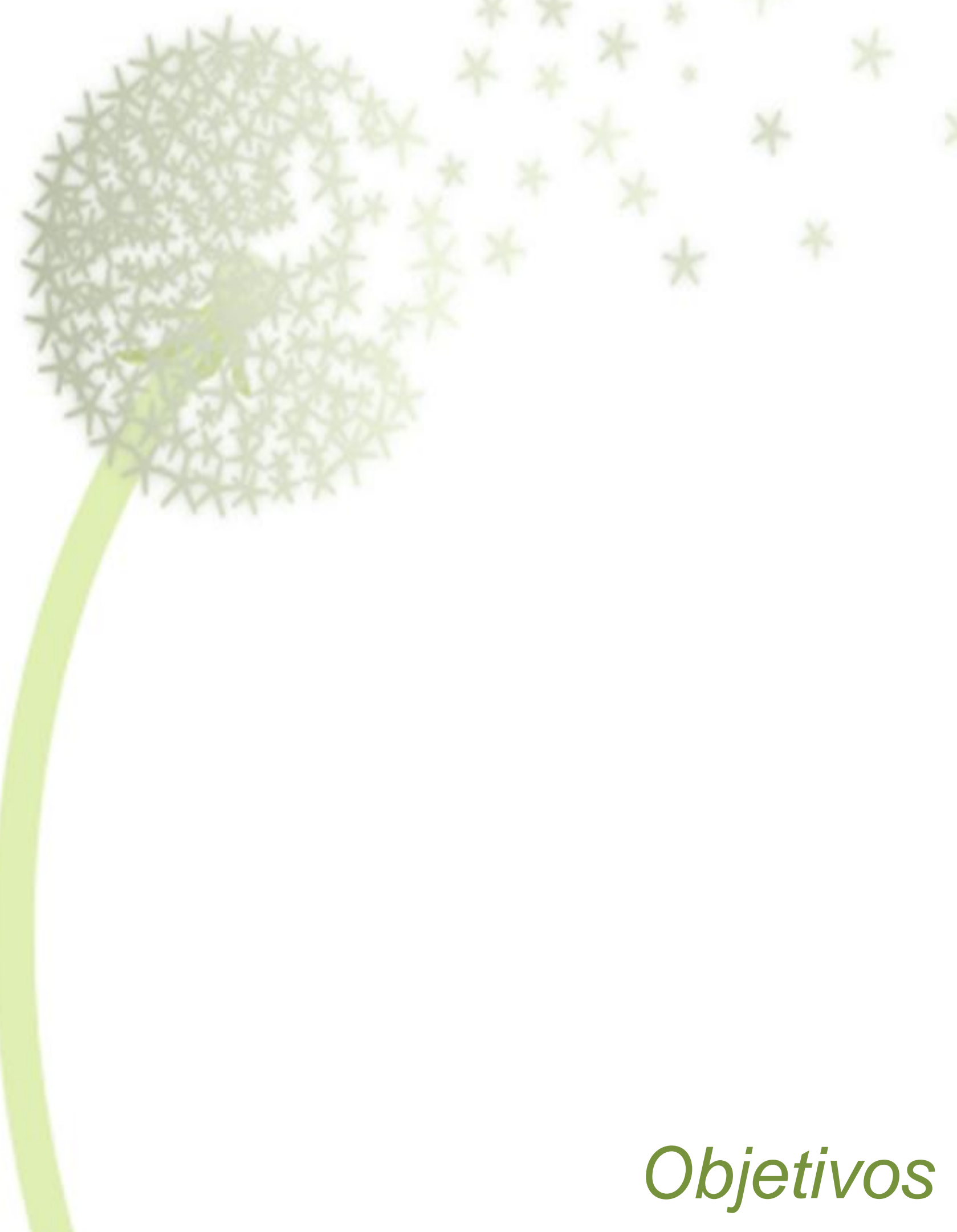




\section{Objetivos}

\subsection{Objetivo Geral}

Analisar a visão de profissionais de saúde que atuam como preceptores no SUS acerca de seu papel nos processos educacionais em cenários de prática.

\subsection{Objetivos Específicos}

- Conhecer o entendimento dos preceptores acerca da natureza da preceptoria;

- Analisar como os preceptores percebem o seu papel nos processos educacionais em cenários de prática;

- Comparar resultados obtidos em diferentes regiões de saúde e de acordo com o sexo, profissão, titulação e campo de atuação. 


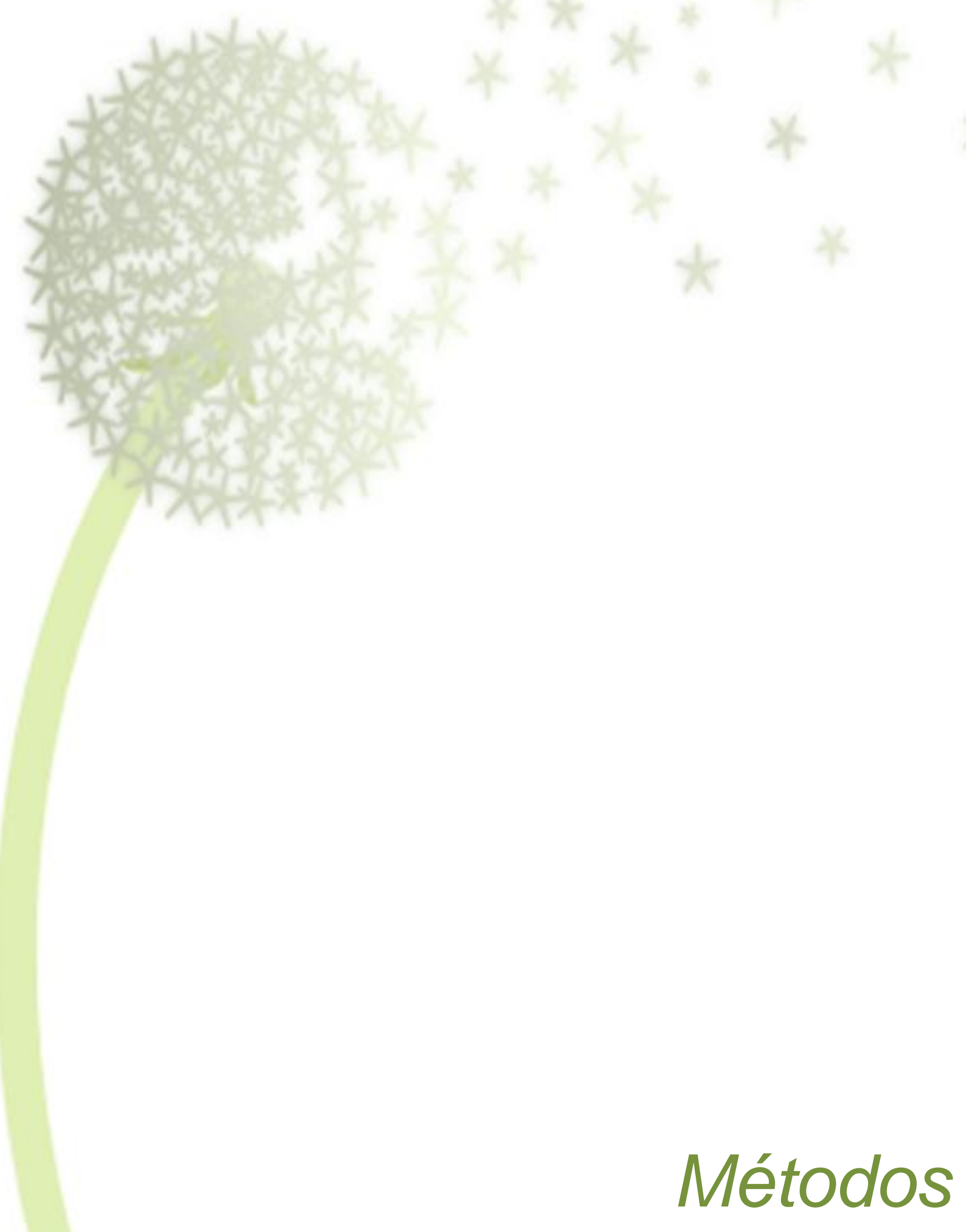




\section{Métodos}

\subsection{Descrição do estudo e coleta de dados}

O presente estudo foi aprovado pelo Comitê de Ética em Pesquisa da Faculdade de Medicina da Universidade de São Paulo (CEP-FMUSP), com protocolo de pesquisa $n^{\circ} 367 / 14$ (Anexo A) e autorizado pelo superintendente de ensino do Instituto de Ensino e Pesquisa do Hospital Sírio Libanês (IEP/HSL), onde foram coletados os dados para a pesquisa (Anexo B).

Trata-se de um estudo exploratório transversal, com abrangência nacional, de abordagem quantitativa e qualitativa. Foi utilizada uma amostra composta por 673 preceptores, concluintes da segunda edição do Curso de Especialização em Educação na Saúde para Preceptores do SUS, oferecido pelo IEP/HSL em vinte regiões de saúde distribuídas pelo território nacional, entre agosto de 2013 e junho de 2014.

Cabe contextualizar que o Curso de Educação na Saúde para Preceptores do SUS foi um dos cursos do Projeto Gestão da Clínica no SUS, desenvolvido pelo Instituto Sírio Libanês de Ensino e Pesquisa, em parceria com Ministério da Saúde, CONASS e CONASEMS. Este projeto faz parte do Programa de Apoio ao Desenvolvimento Institucional do Sistema Único de Saúde (PROADI-SUS), que visa melhorias no SUS por meio de intervenções de caráter tecnológico, gerencial ou de capacitação profissional. O curso tem como objetivo capacitar profissionais em educação na saúde, para que possam desempenhar seu papel de preceptores de maneira a favorecer o aprendizado em prática nos cenários do SUS ${ }^{75}$. 
Inicialmente, foram convidadas as 20 regiões de saúde que sediaram a segunda edição do curso: Arapiraca-AL, Campo Grande-MS, Caruaru-PE, Caxias do Sul-RS, Crato-Juzeiro-CE, Curitiba-PR, Distrito Federal-DF, Dourados-MS, Maringá-PR, Palmas-TO, Porto Velho-RO, Quixadá-CE, Salvador-BA, Santarém-PA, São Luis-MA, Sobral-CE, Teresina-PI, Três Lagoas-MS, Uberaba-MG e Volta Redonda-RJ (Figura 2).

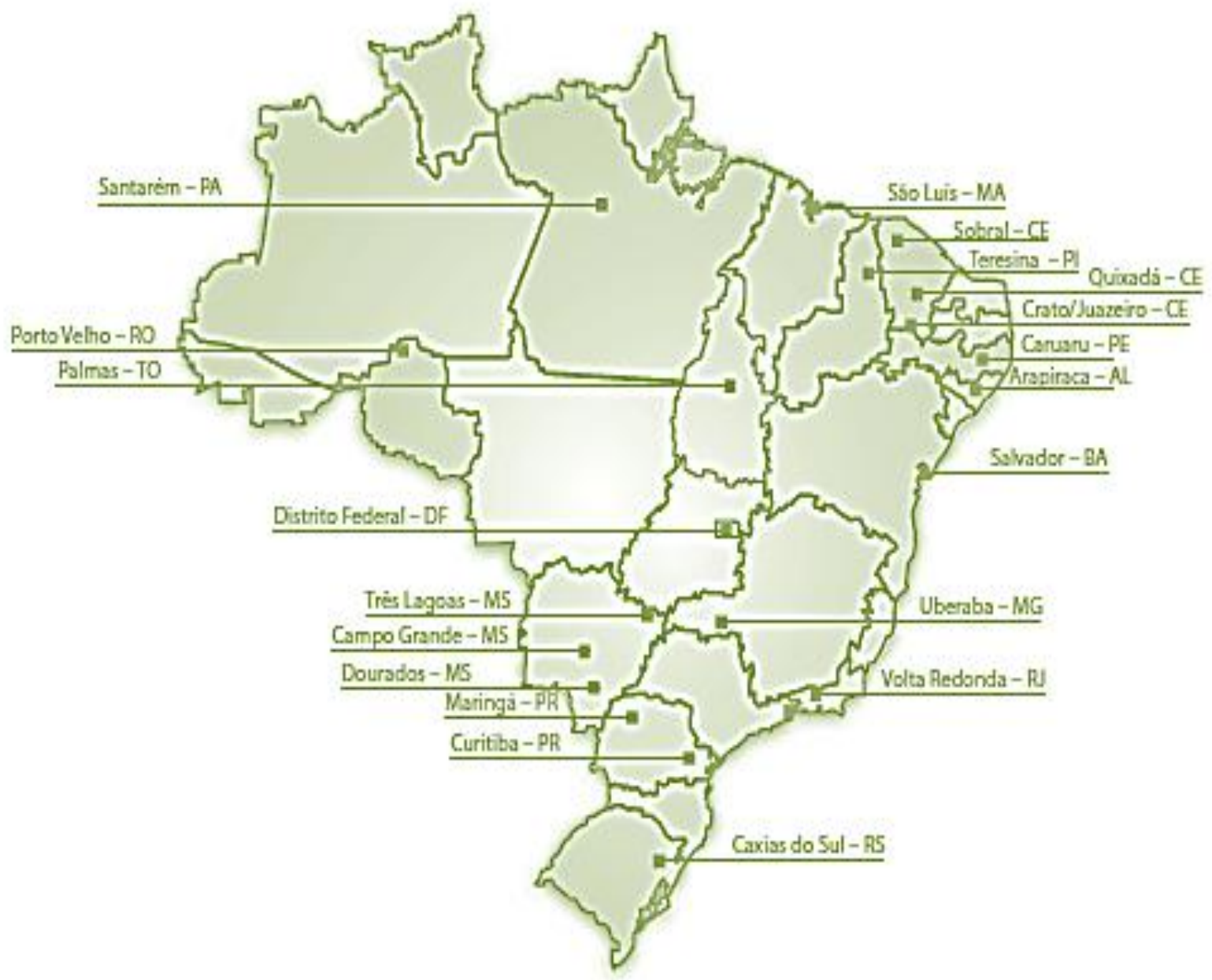

Fonte: IEP/HSL, 2013.

Figura 2 - Regiões de saúde que sediaram a segunda edição do Curso de Especialização em Educação na Saúde para Preceptores do SUS, IEP/HSL

O instrumento de coleta de dados (Anexos C e D) e o Termo de Consentimento Livre e Esclarecido (TCLE) (Anexo E) impressos foram 
enviados às vinte regiões de saúde, com uma carta contendo justificativa e objetivos do estudo, além de orientações para coleta de dados. A coleta de dados foi realizada localmente pelos facilitadores do curso, em dezoito das vinte regiões de saúde participantes, entre maio e junho de 2014, ao término das atividades regulares do curso. Os questionários e o TCLE preenchidos foram devolvidos à pesquisadora ao término da coleta. As respostas aos questionários foram digitadas e preparadas para análise.

A participação no estudo foi voluntária e não previu qualquer tipo de remuneração ou vantagem de outra natureza, e foi condicionada à assinatura do TCLE, estando garantidos o anonimato e a confidencialidade das respostas.

\subsection{Construção e sintaxe do instrumento de coleta de dados}

$\mathrm{Na}$ construção do instrumento de coleta de dados quantitativos, optou-se pelo modelo de questionário com afirmações em escala do tipo Likert de cinco pontos - concordo totalmente $(\mathrm{CT})$, concordo parcialmente $(\mathrm{CP})$, indiferente $(\mathrm{I})$, discordo parcialmente (DP) e discordo totalmente (DT). Este instrumento, elaborado pela pesquisadora, teve como foco a percepção dos preceptores acerca da preceptoria e do seu papel nos processos educacionais em cenários de prática. Além de 35 afirmações com resposta em escala do tipo Likert, o

instrumento continha dados sócio demográficos e duas perguntas abertas. A elaboração do instrumento de coleta de dados foi baseada em extensa revisão da literatura e consenso de três especialistas em educação na saúde e 
preceptoria, que revisaram o material individualmente e em conjunto, para validação do constructo.

Foram atribuídos os seguintes escores para cada uma das respostas: $5=$ $\mathrm{CT}, 4=\mathrm{CP}, 3=\mathrm{I}, 2=\mathrm{DP}, 1=\mathrm{DT}$. Afirmações que representavam aspectos negativos com relação à preceptoria tiveram seus valores invertidos para que não houvesse comprometimento da análise dos resultados posteriormente. Exemplo: Afirmativa 1 - "A presença do estudante no ambiente de trabalho sobrecarrega minhas atividades"; nesta questão o CT recebeu pontuação $=1$ e o DT recebeu pontuação $=5$. Sofreram inversão de valores as seguintes questões: 1, 2, 4, 16, 20, 28 e 31 .

\subsection{Análise dos dados}

\subsubsection{Análise dos dados quantitativos}

Os resultados quantitativos obtidos no estudo foram expressos por frequências e percentuais ou por médias e desvios padrão e ilustrados por gráficos e tabelas. A estatística descritiva foi utilizada para a caracterização sócio demográfica da população estudada e para determinação dos escores do instrumento utilizado. Para avaliação da independência entre variáveis categóricas, foi aplicado o teste de Qui-quadrado. Em todos os casos, um valor de $p$ igual ou inferior a 0,05 foi considerado estatisticamente significativo. 0 programa estatístico utilizado foi o $R$ Software, versão 3.1.1.

A confiabilidade dos dados foi verificada por meio da consistência interna do instrumento utilizado para coleta dos dados por meio do coeficiente 
de alfa de Cronbach. Valores maiores ou iguais a 0,7 são considerados satisfatórios para estudos de grupos ${ }^{76,77}$.

A qualidade dos dados coletados com o instrumento foi determinada através da coerência dos efeitos piso (porcentagem dos respondentes no escore mínimo do instrumento) e teto (porcentagem dos respondentes no escore máximo do instrumento). A ocorrência dos efeitos de piso e teto seria estabelecida caso mais de $10 \%$ dos respondentes apresentasse escore mínimo ou máximo da afirmação ${ }^{78}$.

A análise quantitativa do instrumento compreendeu as seguintes etapas:

- Conferência: todos os 35 itens do instrumento de coleta de dados foram conferidos e deveriam apresentar valores inteiros entre 1 e 5 . Foi atribuído um valor igual a zero para as afirmativas não respondidas ou preenchidas indevidamente.

- Inversão de valores: As afirmativas 1, 2, 4, 16, 20, 28 e 31 foram elaboradas no sentido negativo, ao contrário das demais, por isso, nestes casos houve inversão do escore atribuído em cada uma delas.

- Exclusão dos dados perdidos: os questionários que continham mais de $20 \%$ de dados preenchidos indevidamente ou não respondidos foram excluídos da análise.

- Aplicação da estatística descritiva.

$\mathrm{Na}$ análise de item do instrumento, inicialmente, foram construídos gráficos de frequência das cinco diferentes possibilidades de resposta (CT, CP, I, DP, DT) para cada uma das 35 afirmações propostas. Em seguida, foi feito um agrupamento das respostas CT e CP, para o qual foi atribuida uma percepção positiva dos respondentes com relação à afirmacão. As respostas I, 
DP e DT, foram agrupadas da mesma forma e consideradas como percepções negativas acerca da afimativa, ou seja, pontos sobre a preceptoria que poderiam ser melhorados, ou que mereceriam mais atencão, na visão dos preceptores.

A análise dos dados quantitativos foi complementada por uma análise fatorial por componentes princiais e rotação varimax, a partir da qual foram realizadas comparações entre região, sexo, profissão, titulação e área de atuação.

Para análise da percepção dos preceptores em cada fator, foram atribuídos escores resultantes da somatória dos itens que o compuseram. Desta forma, cada fator teve escores mínimo e máximo. A partir deste cálculo, cada fator teve uma faixa possível de escores e um escore médio, sendo que foram consideradas percepções mais positivas os casos de médias mais altas e percepções menos positivas as médias mais baixas ${ }^{79,80}$.

\subsubsection{Análise dos dados qualitativos}

A análise dos dados qualitativos compreendeu as seguintes etapas: a) Preparação do material - digitação das respostas das questões abertas e organização dos dados; b) Pré-análise - realização de leitura flutuante; c) Categorização - destaque de assuntos por relevância e/ou por repetição, transformando dados brutos em organizados; d) Validação externa - discussão dos resultados entre pesquisadores independentes; e) Apresentação dos 
resultados - de forma descritiva e com citações ilustrativas das falas, preparando o resultado para discussão, inferência e interpretação ${ }^{81-84}$.

Os dados qualitativos neste estudo permitiram identificar a compreensão dos significados atribuídos às vivências e às crenças dos participantes com relação à preceptoria e ao seu papel de preceptor na formação de outros profissionais. Este enfoque qualitativo proporcionou, portanto, uma compreensão do sentido dos acontecimentos para aqueles que os viveram ${ }^{79}$.

A pesquisa qualitativa cumpre este papel de evidenciar percepções e apresenta-las diante de uma gama de possibilidades culturais, afirmando seu uso na pesquisa exploratória ${ }^{81}$. Ser instrumento gerador de ideias e auxiliar na avaliação do estudo quantitativo são funções da pesquisa qualitativa ${ }^{84}$, exploradas no presente estudo. 


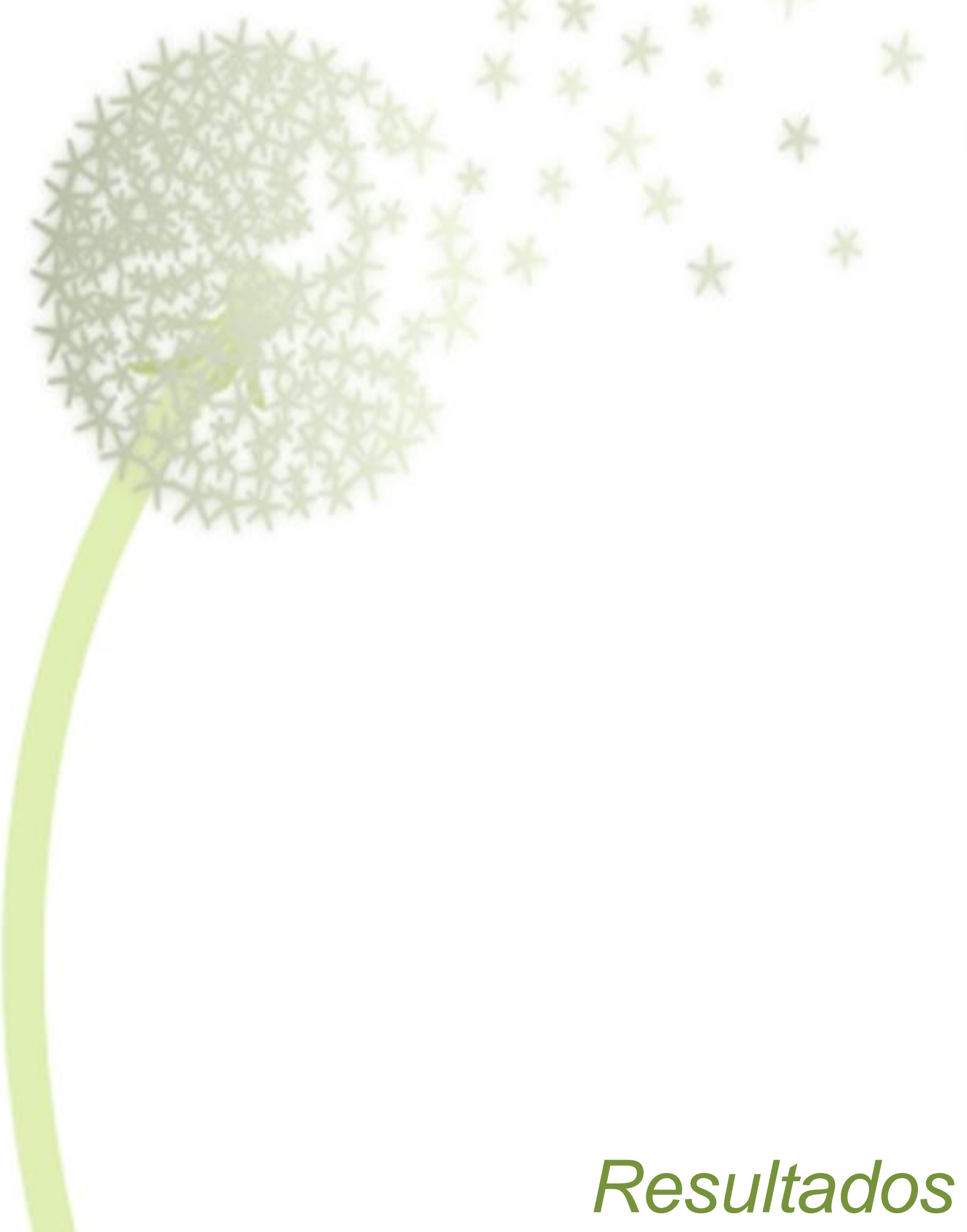




\section{Resultados}

\subsection{Caracterização da amostra}

Do universo total de 715 inscritos nas 20 regiões de saúde na segunda edição do Curso de Educação na Saúde para Preceptores do SUS, houve 673 concluintes aprovados, aptos para participar deste estudo.

Das vinte regiões de saúde onde o curso foi oferecido, duas não participaram da pesquisa, Juazeiro/Crato-CE ( $n=32$ preceptores concluintes) e São Luis-MA ( $n=22$ preceptores concluintes) devido a extravio do material de pesquisa. Foram convidados 619 (100,0\%) alunos e 342 (55,25\%) aceitaram participar do estudo. Entre os participantes, 15 (2,42\%) foram desconsiderados nas análises devido ao preenchimento incompleto dos dados, ou seja, menos de $80 \%$ de preenchimento do questionário. As análises incluíram um total de $327(52,83 \%)$ sujeitos (Figura 3).

Entre os participantes, $264(80,73 \%)$ eram do sexo feminino, 58 (17,74\%) do sexo masculino e 5 (1,53\%) não informaram o sexo. A idade média foi de 37,67 anos, variando entre 22 e 65 anos. Quanto à graduação, 42 (12,84\%) participantes não informaram nenhum curso. Dos respondentes, 115 (35,17\%) eram enfermeiros, 29 (8,87\%) médicos, 26 (7,95\%) fisioterapeutas, 22 (6,72\%) assistentes sociais, 21 (6,42\%) psicólogos, 14 (4,28\%) dentistas, 16 (4,89\%) farmacêuticos e $42(12,84 \%)$ profissionais de outros cursos de graduação (Figura 4). 


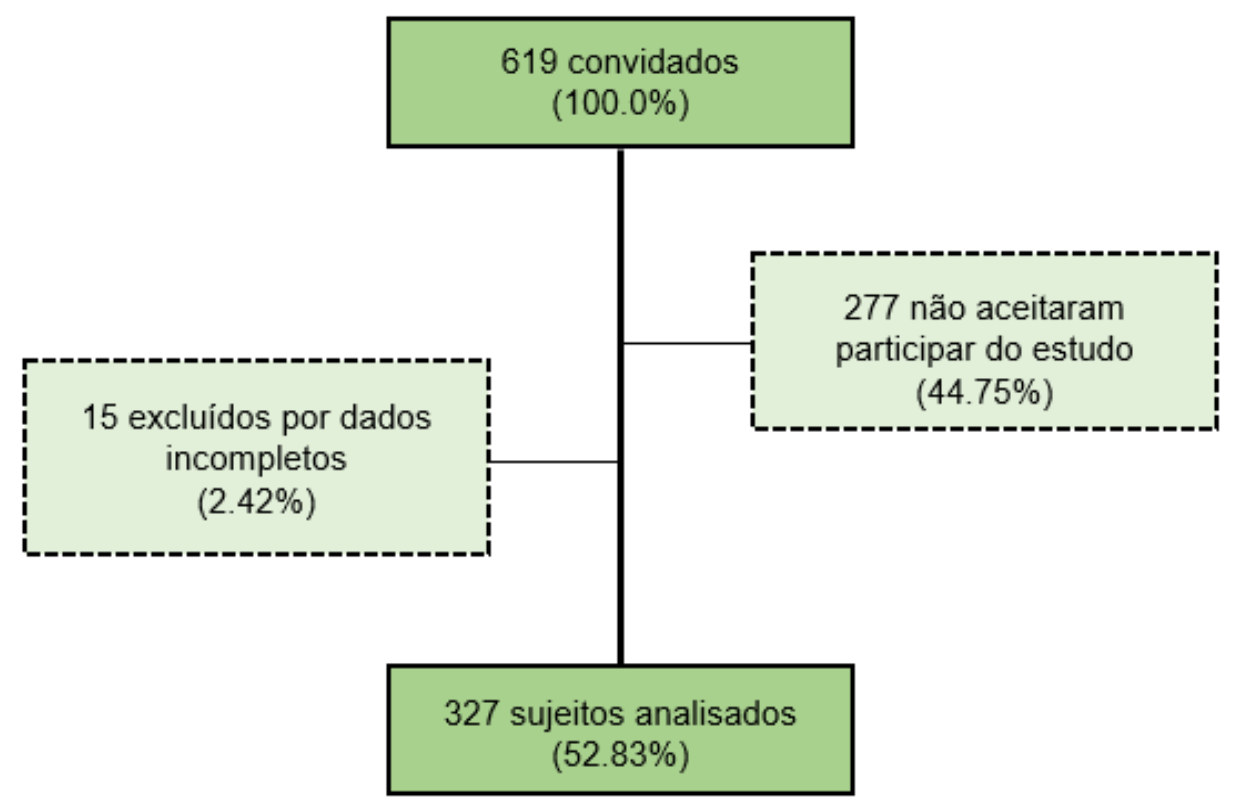

Figura 3 - Fluxograma de participantes e perdas do estudo

$35,17 \%$

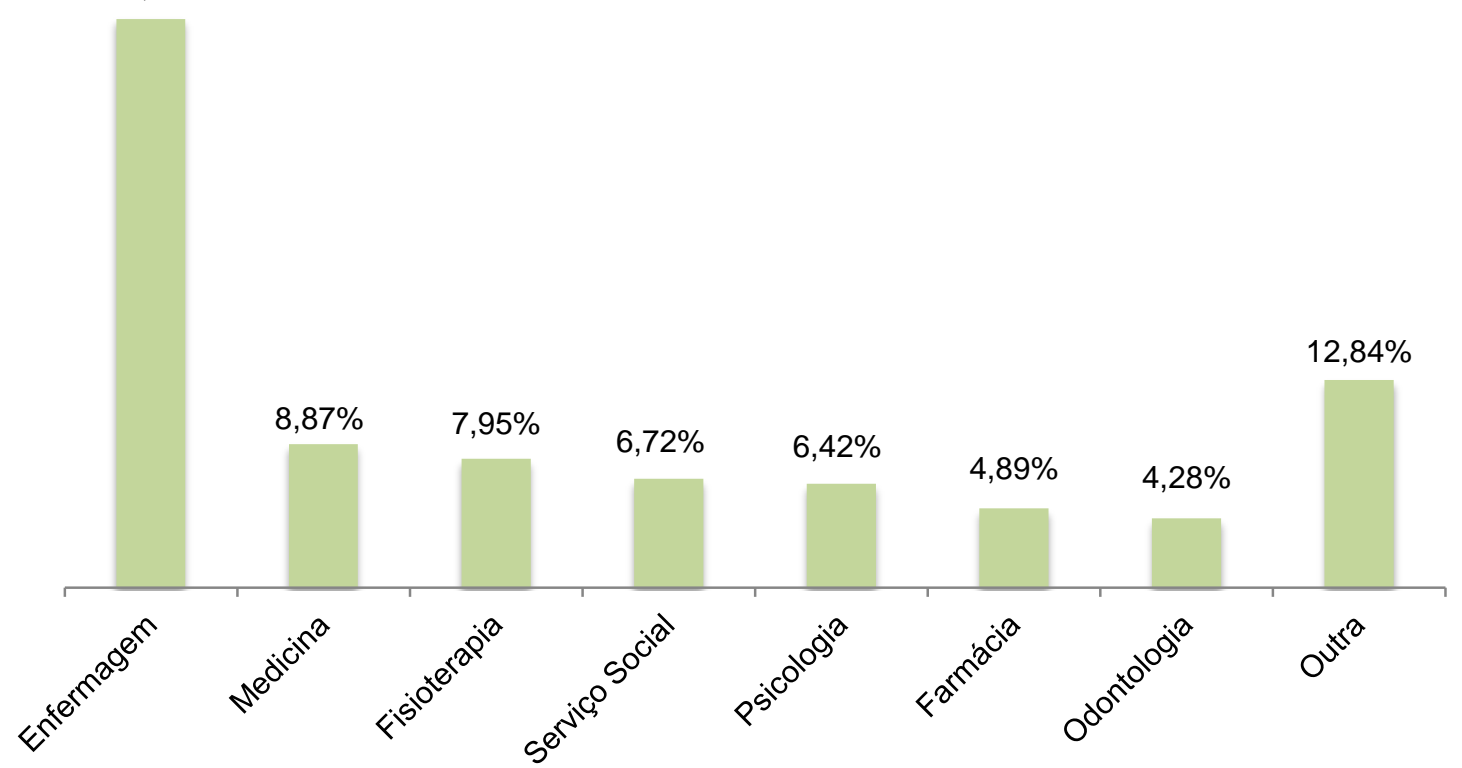

Figura 4 - Distribuição percentual dos participantes quanto à área de graduação 
Quanto à titulação, 246 (75,23\%), participantes afirmaram ter feito curso de especialização lato sensu, 21 (6,42\%) residência, 49 (14,98\%) mestrado e 11 $(3,36 \%)$ doutorado. Neste item foi considerada a maior titulação informada pelos respondentes.

O tempo de experiência com educação em saúde informado pelos participantes variou entre zero e 38 anos, com mediana igual a 3 anos. Todos os profissionais atuavam no serviço público de saúde e suas atividades foram classificadas em três possíveis áreas de atuação: assistência $(n=221)$, gestão ( $n=93)$ e educação $(n=148)$, sendo possível assinalar mais de uma opção. Entre os 327 respondentes, nove (2,75\%) não assinalaram nenhuma das três opções (Figura 5).

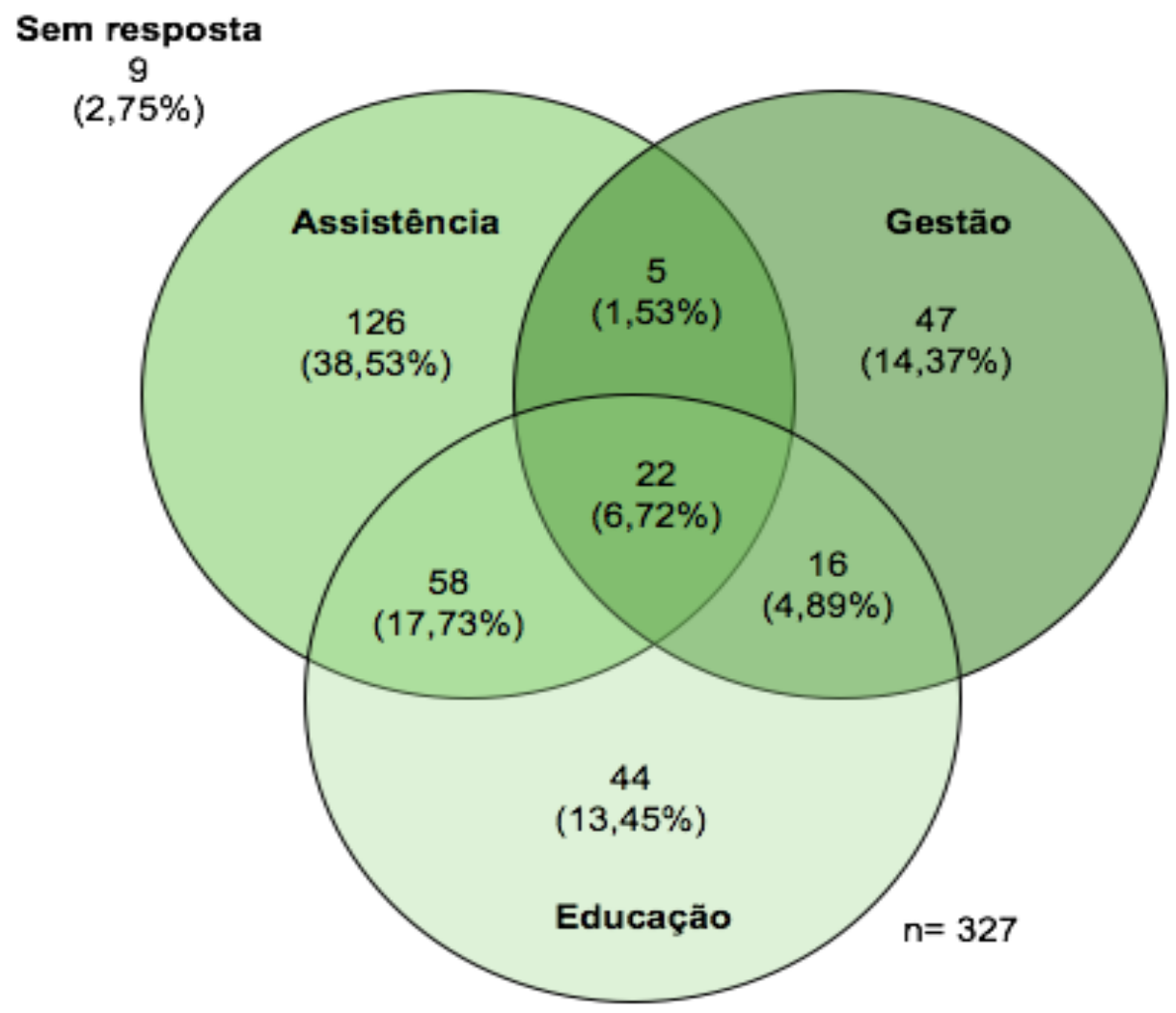

Figura 5 - Distribuição dos participantes por área de atuação 
Foram ofertadas 48 vagas para cada uma das 20 regiões contempladas com o curso. Considerando as regiões do território nacional, foram ofertadas 96 vagas (10\%) para a região norte, 384 vagas (40\%) para a região nordeste, 192 (20\%) para a região centro-oeste e as regiões sudeste e sul foram contempladas com 144 vagas (15\%) cada uma.

A análise do número de preceptores que aceitaram participar do estudo em cada uma das regiões está representada na Tabela 1, onde se pode notar que a região com maior porcentagem de respondentes foi o Sul $(67,57 \%)$ e a região com menor adesão de respostas ao instrumento de coleta de dados foi 0 Nordeste (32,57\%).

Levando em consideração o número de preceptores respondentes por região, foi possível calcular a representatividade de cada região no estudo e constatou-se que o Nordeste e o Centro-Oeste, que contribuíram com 25,99\% cada uma, totalizando 85 instrumentos de coleta de dados preenchidos de maneira satisfatória para inclusão no estudo, sendo a maio representatividade. A região Norte, por outro lado, apresentou uma representatividade de $13,46 \%$ no estudo e um total de 44 participantes (Tabela 1).

Tabela 1 - Distribuição de concluintes e respondentes por região e representatividade de cada região no estudo

\begin{tabular}{lccc}
\hline Região & $\begin{array}{c}\text { Concluintes } \\
\mathrm{n}\end{array}$ & $\begin{array}{c}\text { Respondentes por } \\
\text { região } \\
\mathrm{n}(\%)\end{array}$ & $\begin{array}{c}\text { Representatividade da } \\
\text { região no estudo } \\
\mathrm{n}(\%)\end{array}$ \\
\hline Norte & 67 & $44(65,70)$ & $44(13,46)$ \\
Nordeste & 261 & $85(32,57)$ & $85(25,99)$ \\
Centro-Oeste & 131 & $85(64,90)$ & $85(25,99)$ \\
Sudeste & 103 & $38(36,90)$ & $38(11,60)$ \\
Sul & 111 & $75(67,57)$ & $75(22,90)$ \\
\hline Total & 673 & $327(100,00)$ & $327(100,00)$ \\
\hline
\end{tabular}




\subsubsection{Caracterização da amostra por região}

Durante o processo de caracterização da amostra, foram analisadas as informações relativas a sexo, graduação e formação isoladamente em cada região (Tabelas 2, 3 e 4).

Os dados demonstrados na Tabela 2 indicam que a presença de maioria de respondentes do sexo feminino encontrada na caracterização geral da amostra no país se mantém quando realizada a análise por região. As porcentagens de preceptoras variaram entre 76,00 e $89,00 \%$ entre as regiões, sendo a região sudeste a que apresenta maior concentração de respondentes do sexo feminino.

Tabela 2 - Distribuição regional dos respondentes por sexo

\begin{tabular}{lcccccc}
\hline Sexo & Centro-Oeste & Nordeste & Norte & Sudeste & Sul & Total \\
& $\mathrm{n}(\%)$ & $\mathrm{n}(\%)$ & $\mathrm{n}(\%)$ & $\mathrm{n}(\%)$ & $\mathrm{n}(\%)$ & $\mathrm{n}(\%)$ \\
\hline Feminino & $65(76,00)$ & $72(84,00)$ & $34(77,00)$ & $34(89,00)$ & $59(78,00)$ & $264(80,00)$ \\
Masculino & $17(20,00)$ & $13(15,00)$ & $9(20,0)$ & $4(10,00)$ & $15(20,00)$ & $58(17,00)$ \\
Sem resposta & $3(3,50)$ & $0(0,00)$ & $1(2,20)$ & $0(0,00)$ & $1(1,30)$ & $5(1,50)$ \\
\hline Total & $85(100,00)$ & $85(100,00)$ & $44(100,00)$ & $38(100,00)$ & $75(100,00)$ & $327(100,00)$ \\
\hline
\end{tabular}

Assim como na caracterização nacional da amostra, a Tabela 3 demonstra que, neste estudo, a maioria dos participantes de cada uma das regiões do país eram graduados em enfermagem, sendo a região sul aquela com maior concentração de enfermeiros $(38,00 \%)$ e a região norte com a menor concentração $(25,00 \%)$. A região sul foi a que apresentou também o maior número de profissionais médicos $(14,00 \%)$ e dentistas $(9,30 \%)$ e o menor 
número de assistentes sociais (2,60\%), além de não ter apresentado nenhum fisioterapeuta entre os respondentes. A região norte apresentou a menor concentração de médicos $(4,70 \%)$ e a maior concentração de assistentes sociais $(11,00 \%)$. Na região norte foi encontrado o maior número de preceptores graduados em fisioterapia (18,00\%), enquanto esta foi a região com menor número de psicólogos $(9,00 \%)$ e nenhum profissional farmacêutico ou dentista. No centro-oeste, $8,20 \%$ dos respondentes eram farmacêuticos e nenhum dentista. A região sudeste apresentou maior número de profissionais de outras profissões e menor número de psicólogos.

Tabela 3 - Distribuição regional dos respondentes por curso de graduação

\begin{tabular}{lcccccc}
\hline Graduação & $\begin{array}{c}\text { Centro-Oeste } \\
\mathrm{n}(\%)\end{array}$ & $\begin{array}{c}\text { Nordeste } \\
\mathrm{n}(\%)\end{array}$ & $\begin{array}{c}\text { Norte } \\
\mathrm{n}(\%)\end{array}$ & $\begin{array}{c}\text { Sudeste } \\
\mathrm{n}(\%)\end{array}$ & $\begin{array}{c}\text { Sul } \\
\mathrm{n}(\%)\end{array}$ & $\begin{array}{c}\text { Total } \\
\mathrm{n}(\%)\end{array}$ \\
\hline Enfermagem & $31(36,00)$ & $30(35,00)$ & $11(25,00)$ & $14(36,00)$ & $29(38,00)$ & $115(35,00)$ \\
Medicina & $8(9,40)$ & $4(4,70)$ & $6(13,00)$ & $0(0,00)$ & $11(14,00)$ & $29(8,80)$ \\
Fisioterapia & $3(3,50)$ & $12(14,00)$ & $8(18,00)$ & $3(7,80)$ & $0(0,00)$ & $26(7,90)$ \\
Serviço Social & $4(4,70)$ & $10(11,00)$ & $4(9,00)$ & $2(5,20)$ & $2(2,60)$ & $22(6,70)$ \\
Psicologia & $6(7,00)$ & $6(7,00)$ & $4(9,00)$ & $1(2,60)$ & $4(5,30)$ & $21(6,40)$ \\
Farmácia & $7(8,20)$ & $5(5,80)$ & $0(0,00)$ & $2(5,20)$ & $2(2,60)$ & $16(4,80)$ \\
Odontologia & $0(0,00)$ & $5(5,80)$ & $0(0,00)$ & $2(5,20)$ & $7(9,30)$ & $14(4,20)$ \\
Outra & $14(16,00)$ & $7(8,20)$ & $5(11,00)$ & $8(21,00)$ & $8(10,00)$ & $42(12,00)$ \\
Sem resposta & $12(14,00)$ & $6(7,00)$ & $6(13,00)$ & $6(15,00)$ & $12(16,00)$ & $42(12,00)$ \\
\hline Total & $85(100,00)$ & $85(100,00)$ & $44(100,00)$ & $38(100,00)$ & $75(100,00)$ & $327(100,00)$ \\
\hline
\end{tabular}

Nos dados da Tabela 4 pode-se perceber que, na região sul estava a maior concentração de respondentes com título de especialização obtido em programa de residência $(12,00 \%)$ e de doutores $(6,60 \%)$. Um total de $20,00 \%$ dos respondentes das regiões norte e sul eram mestres, enquanto no centrooeste $8,20 \%$ dos respondentes afirmaram possuir título de mestrado. 
Tabela 4 - Distribuição regional dos respondentes por titulação

\begin{tabular}{lcccccc}
\hline Titulação & $\begin{array}{c}\text { Centro-Oeste } \\
\mathrm{n}(\%)\end{array}$ & $\begin{array}{c}\text { Nordeste } \\
\mathrm{n}(\%)\end{array}$ & $\begin{array}{c}\text { Norte } \\
\mathrm{n}(\%)\end{array}$ & $\begin{array}{c}\text { Sudeste } \\
\mathrm{n}(\%)\end{array}$ & $\begin{array}{c}\text { Sul } \\
\mathrm{n}(\%)\end{array}$ & $\begin{array}{c}\text { Total } \\
\mathrm{n}(\%)\end{array}$ \\
\hline Especialização & $69(81,00)$ & $68(8,00)$ & $32(72,00)$ & $31(81,00)$ & $46(61,00)$ & $246(75,00)$ \\
Residência & $7(8,20)$ & $3(3,50)$ & $2(4,50)$ & $0(0,00)$ & $9(12,00)$ & $21(6,40)$ \\
Mestrado & $7(8,20)$ & $13(15,00)$ & $9(20,00)$ & $5(13,00)$ & $15(20,00)$ & $49(14,00)$ \\
Doutorado & $2(2,30)$ & $1(1,10)$ & $1(2,20)$ & $2(5,20)$ & $5(6,60)$ & $11(3,30)$ \\
\hline Total & $85(100,00)$ & $85(100,00)$ & $44(100,00)$ & $38(100,00)$ & $75(100,00)$ & $327(100,00)$ \\
\hline
\end{tabular}

\subsection{Análise de confiabilidade do instrumento de coleta de dados quantitativos}

O coeficiente de alfa de Cronbach encontrado na análise de consistência interna do instrumento de coleta de dados quantitativos revelou um alfa $=0,836$, demonstrando a confiabilidade do instrumento. A análise da qualidade dos dados relacionados às respostas obtidas não demonstrou a ocorrência de efeitos piso ou teto.

\subsection{Análise quantitativa da percepção dos preceptores acerca da preceptoria}

\subsubsection{Análise de item}

A partir da análise dos dados quantitativos, foram construídos gráficos que demonstraram a porcentagem de respostas de acordo com a opinião dos respondentes em cada uma das afirmações do instrumento de coleta de dados. 
1. A presença do estudante no ambiente de trabalho sobrecarrega minhas atividades

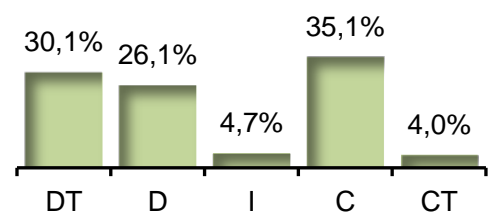

3. A qualidade do meu serviço melhora com a presença do estudante

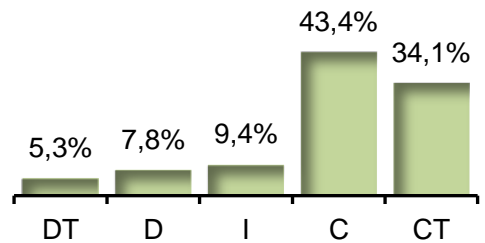

5. A rede de serviço é coresponsável pela formação do profissional de saúde

$66,3 \%$

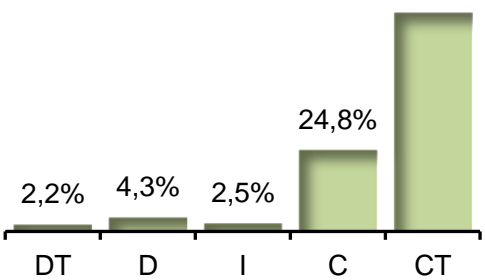

7. Tenho os recursos necessários para desenvolver minhas atividades educacionais

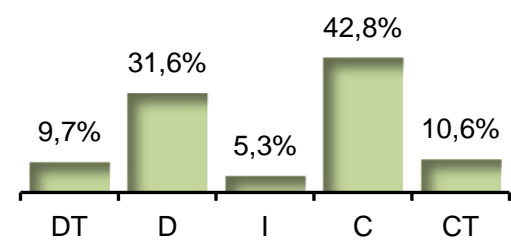

9. Recebi formação pedagógica para desenvolver a preceptoria

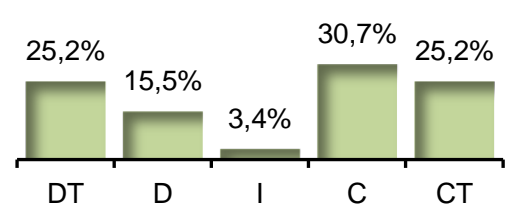

2. A presença do estudante desagrada os usuários

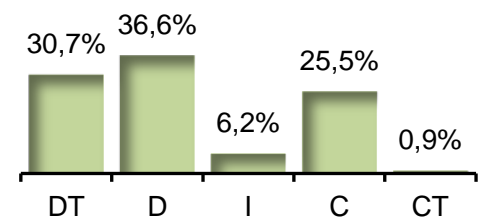

4. Não tenho autonomia para definir propostas educacionais
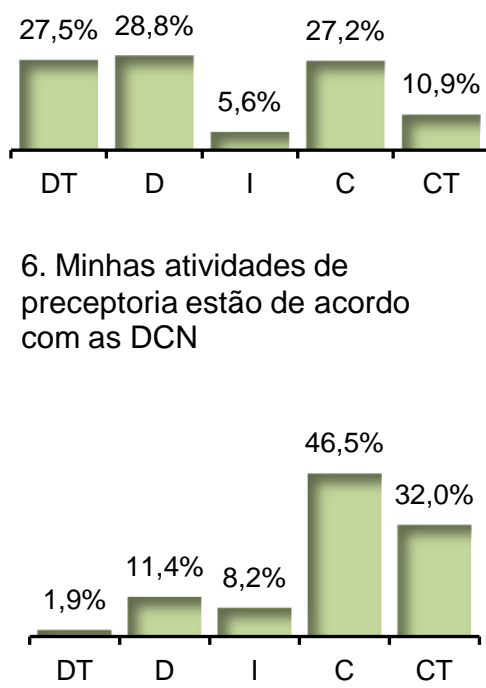

8. Minha atividade de preceptoria integra o estudante na equipe de saúde

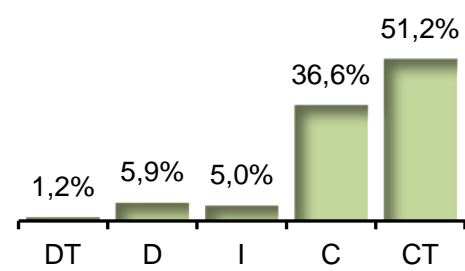

10. Tenho apoio da minha chefia para desenvolver a preceptoria

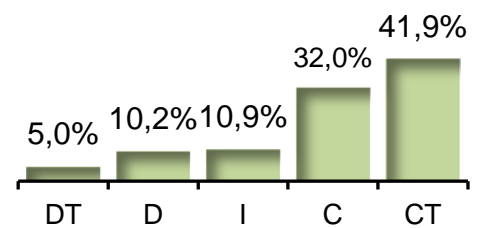

Figura 6 - Análise de item das afirmativas 1 a 10 
11. Sinto-me apto para desenvolver atividades educacionais

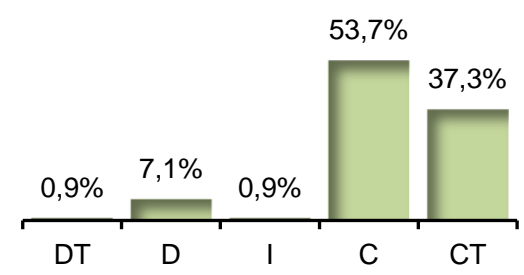

13. Participo dos espaços de discussão da integração ensinoserviço

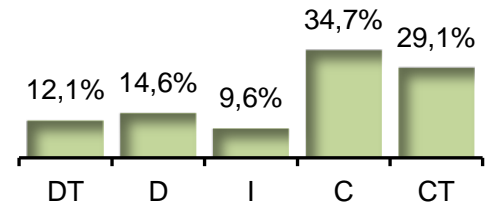

15. Conheço o currículo do curso no qual sou preceptor

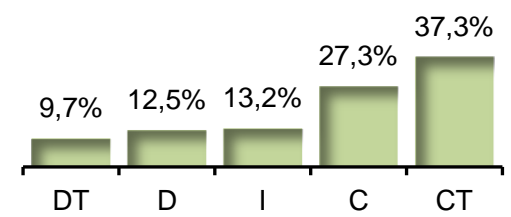

17. Minha atividade de preceptoria é reconhecida pelos profissionais da instituição de ensino superior

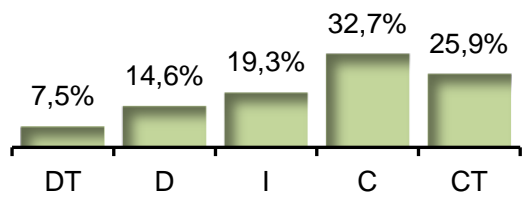

19. Identifico necessidades de saúde da população que tendo para definir objetivos educacionais

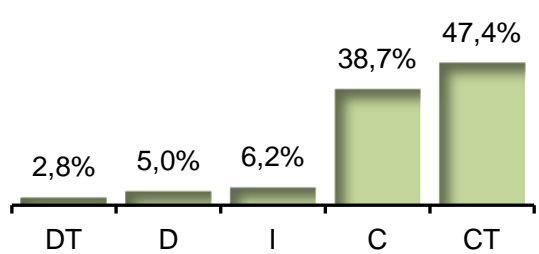

12. Toda a equipe de saúde do meu serviço participa da formação de estudantes

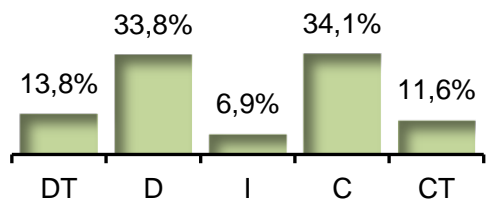

14. Minhas atividades no serviço foram reorganizadas em função da presença dos estudantes

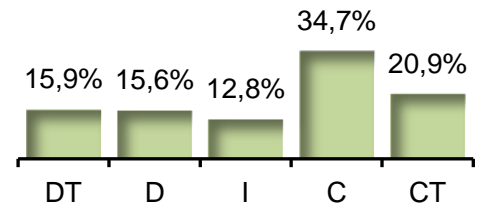

16. A presença do estudante no serviço compromete a segurança do paciente

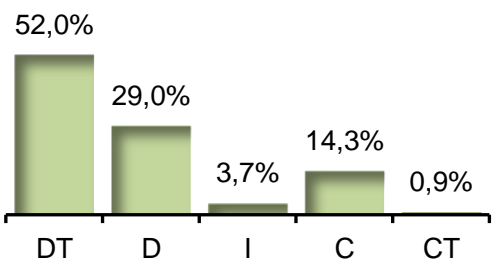

18. A minha prática permite articular aspectos biológicos, sociais e culturais do processo saúde-doença

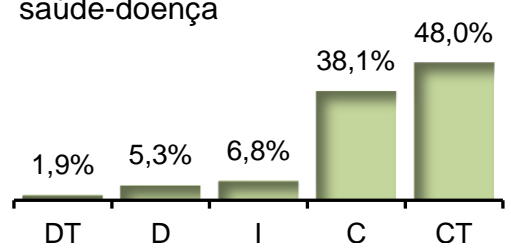

20. Meus objetivos educacionais não levam em conta as necessidades de saúde da população

$60,5 \%$

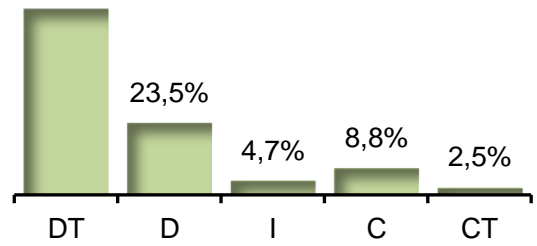

Figura 7 - Análise de item das afirmativas 11 a 20 
21. Utilizo bases de dados para me manter atualizado

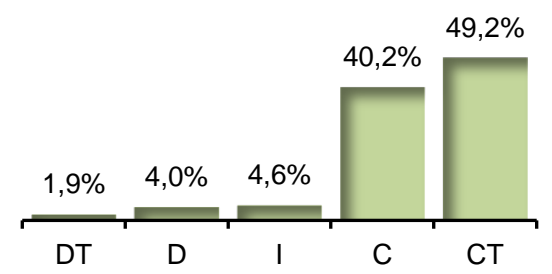

23. Conheço meu estudante e considero seus conhecimentos prévios

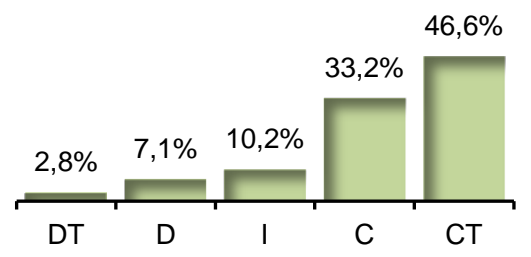

25. Percebo minhas necessidades de aprendizagem

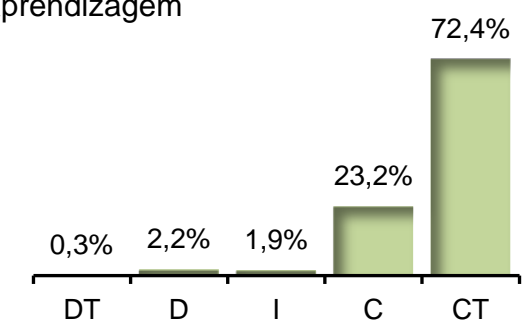

27. Avalio o estudante ao final do processo

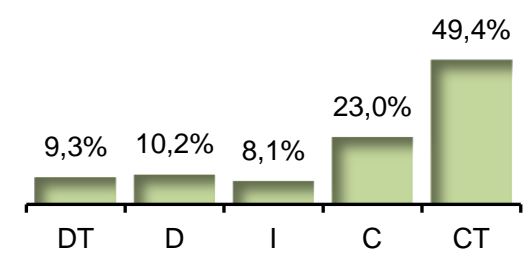

29. Aprendo com meu estudante $85,0 \%$

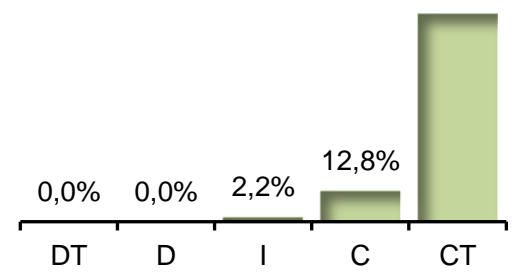

22. Meus objetivos educacionais envolvem atitudes, habilidades e conhecimentos $68,5 \%$

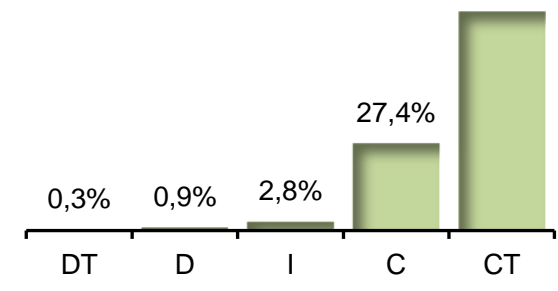

24. Faço correlação teórico-prática na preceptoria

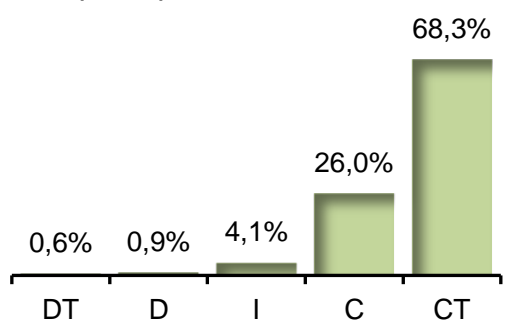

26. Avalio constantemente meu estudante

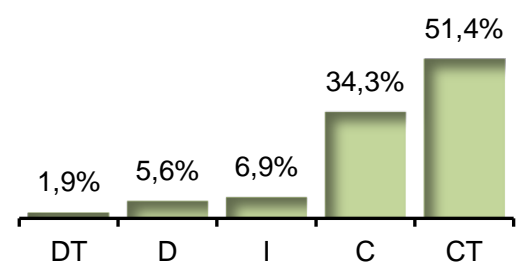

28. A avaliação do estudante não é minha responsabilidade

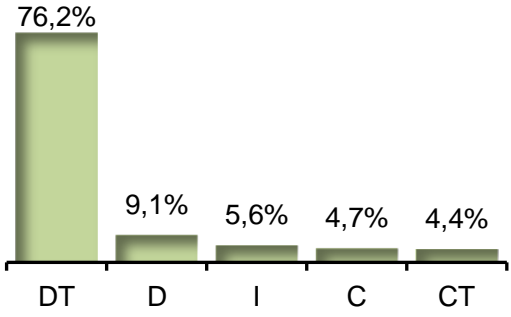

30. Desenvolvo atividades de pesquisa junto aos estudantes

$46,1 \%$

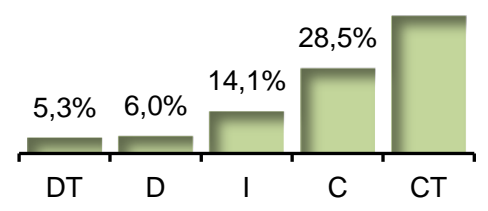

Figura 8 - Análise de item das afirmativas 21 a 30 
31. A presença do estudante no serviço gera conflitos dentro da equipe

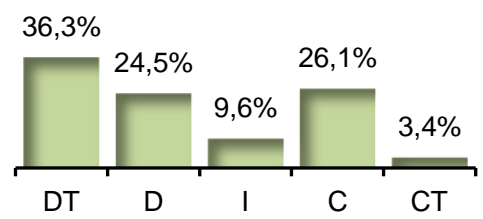

33. Sou remunerado para ser preceptor

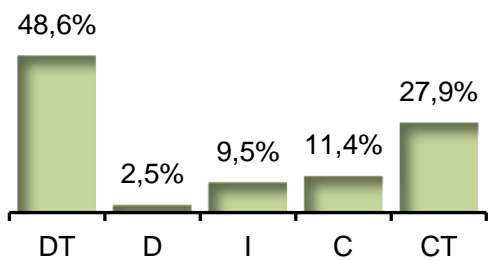

32. O espaço físico do meu trabalho é adequado à preceptoria

35. Minha função de preceptor melhora minha qualidade de vida

34. Tenho interesse em seguir carreira docente

$70,2 \%$

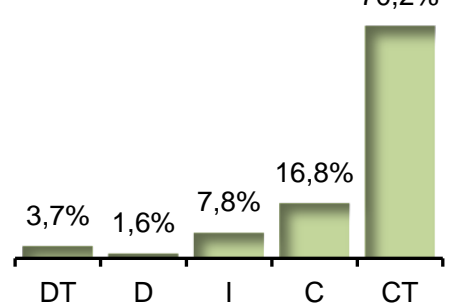

Figura 9 - Análise de item das afirmativas 31 a 35

Posteriormente a esta análise, as respostas foram alocadas em dois grupos, sendo o primeiro correspondente às respostas Concordo totalmente e Concordo Parcialmente e que expressam uma perepção positiva com relação à preceptoria e o segundo grupo correspondente às respostas Indeferente, Discordo Parcialmente e Discordo totalmente, que expressam uma percepção negativa com relação à preceptoria (Tabela 5). 
Tabela 5 - Distribuição de respondentes conforme percepção por item

\begin{tabular}{|c|c|c|}
\hline Afirmação & $\begin{array}{c}\text { Percepção } \\
\text { positiva } \\
(\%)\end{array}$ & $\begin{array}{c}\text { Percepção } \\
\text { negativa } \\
(\%)\end{array}$ \\
\hline $\begin{array}{l}\text { 1. A presença do estudante no ambiente de trabalho sobrecarrega } \\
\text { minhas atividades. }\end{array}$ & 55,60 & 44,40 \\
\hline 2. A presença do estudante desagrada os usuários. & 67,50 & 32,50 \\
\hline 3. A qualidade do meu serviço melhora com a presença do estudante. & 76,90 & 23,10 \\
\hline 4. Não tenho autonomia para definir propostas educacionais. & 56,20 & 43,80 \\
\hline $\begin{array}{l}\text { 5. A rede de serviço é corresponsável pela formação dos profissionais de } \\
\text { saúde. }\end{array}$ & 90,70 & 9,30 \\
\hline $\begin{array}{l}\text { 6. Minhas atividades de preceptoria estão de acordo com as Diretrizes } \\
\text { Curriculares Nacionais. }\end{array}$ & 77,80 & 22,20 \\
\hline $\begin{array}{l}\text { 7. Tenho os recursos necessários para desenvolver minhas atividades } \\
\text { educacionais. }\end{array}$ & 53,30 & 46,70 \\
\hline $\begin{array}{l}\text { 8. Minha atividade de preceptoria integra o estudante na equipe de } \\
\text { saúde. }\end{array}$ & 88,50 & 11,50 \\
\hline 9. Recebi formação pedagógica para desenvolver a preceptoria. & 55,40 & 44,60 \\
\hline 10. Tenho apoio da minha chefia para desenvolver a preceptoria. & 73,80 & 26,20 \\
\hline 11. Sinto-me apto para desenvolver atividades educacionais. & 90,70 & 9,30 \\
\hline $\begin{array}{l}\text { 12. Toda a equipe de saúde do meu serviço participa da formação de } \\
\text { estudantes. }\end{array}$ & 44,90 & 55,10 \\
\hline 13. Participo dos espaços de discussão da integração ensino-serviço. & 63,60 & 36,40 \\
\hline $\begin{array}{l}\text { 14. Minhas atividades no serviço foram reorganizadas em função da } \\
\text { presença dos estudantes. }\end{array}$ & 55,60 & 44,40 \\
\hline 15. Conheço o currículo do curso no qual sou preceptor. & 64,50 & 35,50 \\
\hline $\begin{array}{l}\text { 16. A presença do estudante no serviço compromete a segurança do } \\
\text { paciente. }\end{array}$ & 80,20 & 19,80 \\
\hline $\begin{array}{l}\text { 17. Minha atividade de preceptoria é reconhecida pelos profissionais da } \\
\text { instituição de ensino superior. }\end{array}$ & 57,80 & 42,20 \\
\hline $\begin{array}{l}\text { 18. A minha prática permite articular aspectos biológicos, sociais e } \\
\text { culturais do processo saúde-doenca. }\end{array}$ & 86,10 & 13,90 \\
\hline
\end{tabular}


Continuação

Percepção Percepção

Afirmação

positiva negativa

(\%)

(\%)

19. Identifico necessidades de saúde da população que atendo para definir objetivos educacionais.

$85,10 \quad 14,90$

20. Meus objetivos educacionais não levam em conta as necessidades de saúde da população.

$82,40 \quad 17,60$

21. Utilizo bases de dados para me manter atualizado.

$89,50 \quad 10,50$

22. Meus objetivos educacionais envolvem atitudes, habilidades e conhecimentos.

$96,00 \quad 4,00$

23. Conheço meu estudante e considero seus conhecimentos prévios. $\quad 79,40 \quad 20,60$

24. Faço correlação teórico-prática na preceptoria.

$94,40 \quad 5,60$

25. Percebo minhas necessidades de aprendizagem.

$95,70 \quad 4,30$

26. Avalio constantemente meu estudante.

$85,40 \quad 14,60$

27. Avalio o estudante ao final do processo.

$72,00 \quad 28,00$

28. A avaliação do estudante não é minha responsabilidade.

$85,30 \quad 14,70$

29. Aprendo com meu estudante.

$97,80 \quad 2,20$

30. Desenvolvo atividades de pesquisa junto aos estudantes.

$74,40 \quad 25,60$

31. A presença do estudante no serviço gera conflitos dentro da equipe.

$60,40 \quad 39,60$

32. O espaço físico do meu trabalho é adequado à preceptoria.

$46,00 \quad 54,00$

33. Sou remunerado para ser preceptor.

$38,00 \quad 62,00$

34. Tenho interesse em seguir carreira docente,

$87,00 \quad 13,00$

35. Minha função de preceptor melhora minha qualidade de vida.

$87,00 \quad 13,00$

As respostas revelaram que $44,40 \%$ sentem-se sobrecarregados com a presença do estudante e afirmaram que reorganizaram suas atividades em função da preceptoria, no entanto, $76,90 \%$ afirmaram que a presença do estudante melhora a qualidade do seu serviço. A maioria dos preceptores afirmou que aprende com os estudantes e desenvolve atividades de pesquisa 
junto a eles, além de utilizar bases de dados para atualizar-se $(89,50 \%)$ e ter percepção de suas próprias necessidades de aprendizagem (95,70\%).

Para $77,80 \%$ dos preceptores, suas atividades junto aos estudantes estão de acordo com as DCN e sua prática permite integração de diferentes aspectos do processo saúde-doença, bem como a correlação teórico-prática, mas $43,8 \%$ afirmaram não ter autonomia para definir propostas educacionais. Ainda neste contexto, 35,50\% dos respondentes disseram não conhecer 0 currículo do curso no qual é preceptor.

Os preceptores entendem que a avaliação do estudante é sua responsabilidade $(85,30 \%)$ e que deve ser feita de maneira contínua, ao longo do processo $(85,40 \%)$. Também afirmaram considerar os conhecimentos prévios do estudante no processo de aprendizagem (79,40\%).

Grande parte dos preceptores $(80,20 \%)$ considerou que a presença do estudante não compromete a segurança do paciente, além de a maioria dos respondentes sentir que o estudante no serviço não desagrada os usuários.

Uma alta porcentagem (88,50\%) afirmou que integra os estudantes na equipe de saúde e $90,70 \%$ entendem que a rede de serviços é co-responsável pela formação do profisisonal de saúde. No entanto, 39,60\% dos preceptores colocou a presença do estudante como um potencial fator gerador de conflitos na equipe.

Observaram-se respostas polarizadas em relação às afirmativas sobre recursos e espaço físico adequados para a atividade de preceptoria e sobre o reconhecimento do preceptor pelas IES, o que demonstra diferentes percepções da realidade de acordo com a região do país. 
Após o curso, 90,70\% dos preceptores afirmaram sentir-se aptos para desenvolver atividades educacionais e $87,00 \%$ disseram ter interesse em seguir carreria docente e, apesar de sentirem-se sobrecarregados, a maioria afirmou ter satisfação em ser preceptor, o que pode ser evidenciado pela percepção positiva dos respondentes quanto à melhoria da qualidade de vida diante da atividade de preceptoria.

\subsubsection{Análise fatorial}

A análise fatorial e de rotação varimax (Tabela 6 e Figura 12) delimitou cinco domínios ou fatores principais.

Tabela 6 - Análise fatorial do instrumento de coleta de dados

\begin{tabular}{|c|c|c|c|c|c|c|c|c|c|c|c|}
\hline \multirow{2}{*}{ A } & \multicolumn{11}{|c|}{ Fator } \\
\hline & 1 & 2 & 3 & 4 & 5 & 6 & 7 & 8 & 9 & 10 & 11 \\
\hline 24 & 672 & & & & & & & & & & \\
\hline 21 & ,669 & & & & & & & & & & \\
\hline 23 & 607 & & 337, & & & ,312 & & & & & \\
\hline 22 & ,597 & & & 364 & & & & & & & \\
\hline 26 & ,530 & & & & & ,411 & & & & & \\
\hline 11 & ,408 & 358, & & & & & 375, & & & & \\
\hline 32 & & ,689 & & & & & & & & & \\
\hline 7 & & ,634 & & & & & & & & & \\
\hline 10 & & 620 & & & & & & & & & \\
\hline 17 & & 571 & 348, & & & & & & & & \\
\hline 9 & & ,512 & & & & & & & & &,- 347 \\
\hline 13 & & ,451 & ,442 & & & & & & & & \\
\hline 15 & & & 699 & & & & & & & & \\
\hline 14 & & & 604 & & & & & & & & \\
\hline 30 & & & ,590 & & & & & & & & \\
\hline 6 & 404 & & ,520 & & & & & & & & \\
\hline 8 & 392 & & 393 & & & & & ,350 & & 350, & \\
\hline 19 & & & & 681 & & & & & & & \\
\hline 20 & & & & ,604 & & & & & 358, & & \\
\hline 18 & & & & ,552 & & & & & & & \\
\hline 28 & & & & & ,718 & & & & & & \\
\hline 33 & & & & & 502, & & & &,- 321 & & \\
\hline
\end{tabular}


Continuação

\begin{tabular}{|c|c|c|c|c|c|c|c|c|c|c|c|}
\hline \multirow{2}{*}{ A } & \multicolumn{11}{|c|}{ Fator } \\
\hline & 1 & 2 & 3 & 4 & 5 & 6 & 7 & 8 & 9 & 10 & 11 \\
\hline 16 & & & & ,331 & 499, & -,303 & & 349, & & & \\
\hline 29 & & & & & 433 & 303 & & & & &,- 322 \\
\hline 27 & & & & & & ,717 & & & & & \\
\hline 12 & & & & & & 385, & & & & & \\
\hline 4 & & & & & & 373, & & & & & \\
\hline 34 & & & & & & & ,819 & & & & \\
\hline 35 & & & & & & & ,472 & & & & \\
\hline 31 & & & & & & & & 831, & & & \\
\hline 2 & & & & & & & & & 792 & & \\
\hline 1 & & & & & & & & & ,504 & & \\
\hline 5 & & & & & & & & & & 791 & \\
\hline 3 & & & & & & & & & & & ,722 \\
\hline 25 & & & & & & ,360 & & & & &,- 374 \\
\hline
\end{tabular}

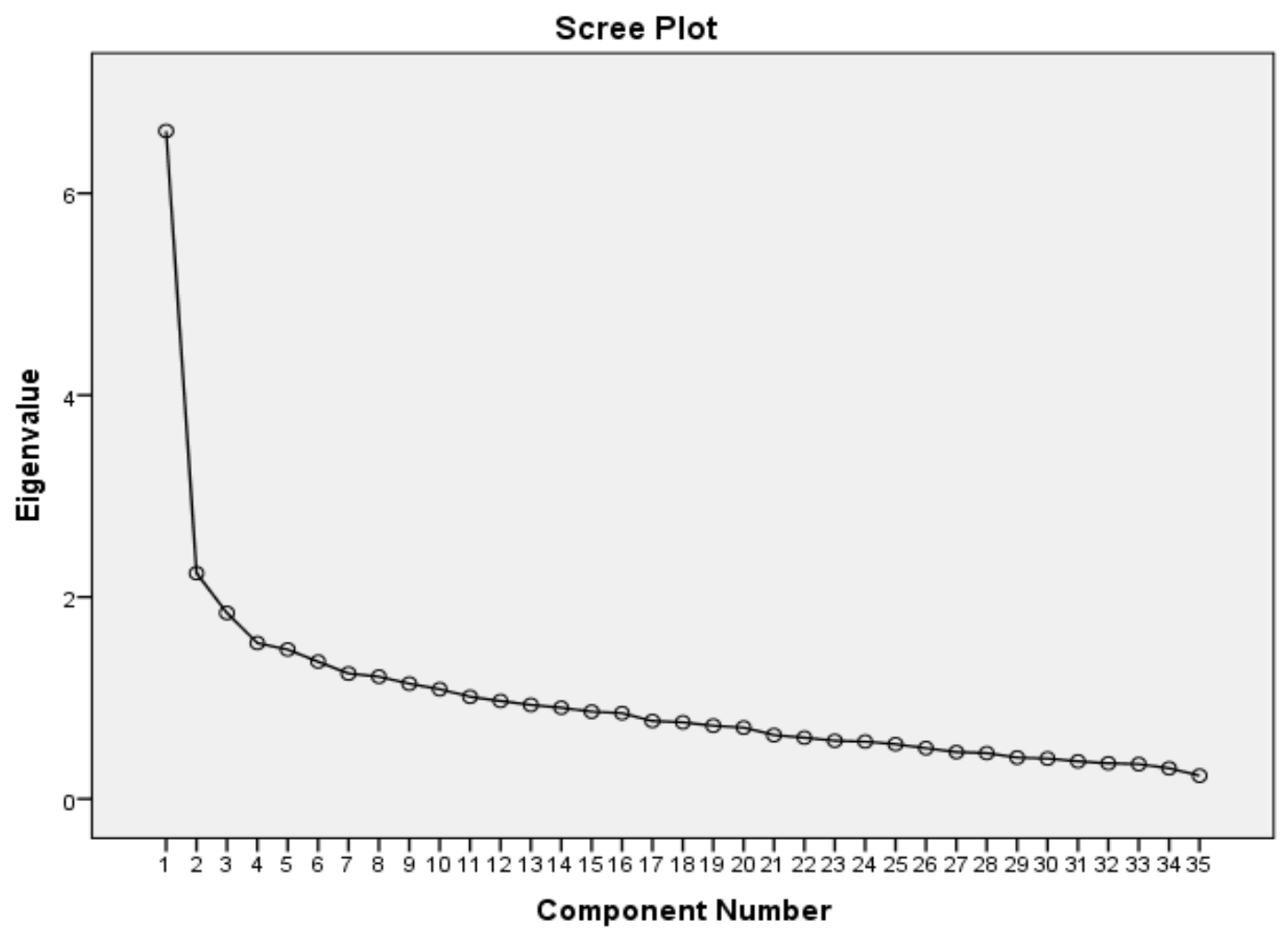

Figura 10 - Análise fatorial do instrumento de coleta de dados 
Os cinco principais fatores identificados foram: F1 - Competência pedagógica, F2 - Suporte e recursos educacionais, F3 - Planejamento do programa educacional, F4 - Integração ensino-serviço, F5 - Presença do estudante no campo de prática.

A Tabela 7 demonstra como foram distribuídas as afirmações dentro de cada um dos cinco fatores. No fator 1 , denominado "Competência pedagógica" estão agrupadas questões acerca do preparo para desempenhar a atividade docente e interesse em seguir nesta carreira. Também contempla afirmações que evidenciam a identificação das próprias necessidades de aprendizagem e atualização dos conhecimentos por meio de busca em literatura. Por fim, avalia o impacto da preceptoria na qualidade de vida do profissional preceptor.

No segundo fator, "Suporte e recursos educacionais" estão as afirmativas relacionadas ao apoio da chefia e reconhecimento da atividade de preceptoria pela IES, adequação de infraestrutura e participação do preceptor em espaços de discussão para a integração ensino-serviço.

O terceiro fator contempla as afirmações que fazem referência ao "Planejamento do programa educacional", destacando a concordância com as DCN, formação interprofissional, currículo acadêmico e propostas educacionais e o papel do profissional preceptor e da equipe do serviço de saúde na formação do estudante.

O fator 4 diz respeito à "Integração ensino-serviço" na preceptoria, onde estão as questões relacionadas à integralidade do cuidado diante da articulação de aspectos biológicos, sociais e culturais do processo saúde- 
doença e necessidades de saúde da população como norteadores dos objetivos educacionais.

O fator 5 foi denominado "Presença do estudante no campo de prática" e nele foram incluídas questões relacionadas aos pontos positivos e negativos da presença do estudante no serviço, desde o aprendizado e melhoria na qualidade do serviço, até as tensões geradas dentro da equipe de saúde e com os usuários. Buscou-se analisar também se os preceptores consideram a presença do estudante como um fator de risco para a segurança do paciente.

Tabela 7 - Fatores delimitados a partir da análise fatorial

\section{Fator 1 - Competência pedagógica}

11. Sinto-me apto para desenvolver atividades educacionais.

21. Utilizo bases de dados para me manter atualizado.

22. Meus objetivos educacionais envolvem atitudes, habilidades e conhecimentos.

23. Conheço meu estudante e considero seus conhecimentos prévios.

24. Faço correlação teórico-prática na preceptoria.

26. Avalio constantemente meu estudante.

25. Percebo minhas necessidades de aprendizagem.

27. Avalio o estudante ao final do processo.

34. Tenho interesse em seguir carreira docente.

35. Minha função de preceptor melhora minha qualidade de vida.

\section{Fator 2 - Suporte e recursos educacionais}

7. Tenho os recursos necessários para desenvolver minhas atividades educacionais.

9. Recebi formação pedagógica para desenvolver a preceptoria.

10. Tenho apoio da minha chefia para desenvolver a preceptoria.

13. Participo dos espaços de discussão da integração ensino-serviço.

17. Minha atividade de preceptoria é reconhecida pelos profissionais da instituição de ensino superior.

32. O espaço físico do meu trabalho é adequado à preceptoria.

\section{Fator 3 - Planejamento do programa educacional}

6. Minhas atividades de preceptoria estão de acordo com as Diretrizes Curriculares Nacionais.

8. Minha atividade de preceptoria integra o estudante na equipe de saúde. 
Continuação

Fator 3 - Planejamento do programa educacional

14. Minhas atividades no serviço foram reorganizadas em função da presença dos estudantes.

15. Conheço o currículo do curso no qual sou preceptor.

30. Desenvolvo atividades de pesquisa junto aos estudantes.

4. Não tenho autonomia para definir propostas educacionais.

5. A rede de serviço é corresponsável pela formação do profissional de saúde.

Fator 4 - Integração ensino-serviço

18. A minha prática permite articular aspectos biológicos, sociais e culturais do processo saúde-doença.

19. Identifico necessidades de saúde da população que tenho para definir objetivos educacionais.

20. Meus objetivos educacionais não levam em conta as necessidades de saúde da população.

\section{Fator 5 - Presença do estudante no campo de prática}

16. A presença do estudante no serviço compromete a segurança do paciente.

33. Sou remunerado para ser preceptor.

28. A avaliação do estudante não é minha responsabilidade.

29. Aprendo com meu estudante.

1. A presença do estudante no ambiente de trabalho sobrecarrega minhas atividades.

2. A presença do estudante desagrada os usuários.

3. A qualidade do meu serviço melhora com a presença do estudante.

12. Toda a equipe de saúde do meu serviço participa da formação de estudantes.

31. A presença do estudante no serviço gera conflitos dentro da equipe.

Conclusão

Nos fatores 1, 3, 4 e 5, a média das respostas ficou acima da média do fator (Tabela 8). Estes resultados demonstram que, no que diz respeito a "Competência pedagógica", "Planejamento do programa educacional", "Integração ensino-serviço" e "Presença do estudante no campo de prática", a percepção dos preceptores foi mais positiva do que negativa.

No fator 2, que agrupou questões relacionadas a "Suporte e recursos educacionais", a média das respostas $(20,20)$ ficou abaixo da média do escore 
para este fator $(21,00)$, o que pode ser um indicativo de que a percepção dos preceptores neste campo é menos positiva.

Tabela 8 - Variação do escore por fator

\begin{tabular}{lcccc}
\hline \multicolumn{1}{c}{ Fator } & $\begin{array}{c}\text { Escore } \\
\text { mínimo } \\
\text { possível }\end{array}$ & $\begin{array}{c}\text { Escore } \\
\text { máximo } \\
\text { possível }\end{array}$ & $\begin{array}{c}\text { Média do } \\
\text { escore }\end{array}$ & $\begin{array}{c}\text { Média das } \\
\text { respostas (DP) }\end{array}$ \\
\hline 1- Competência pedagógica & 10 & 50 & 35,00 & $43,50(10,00)$ \\
2 - Suporte e recursos educacionais & 6 & 30 & 21,00 & $20,20(8,30)$ \\
3 - Planejamento do programa educacional & 7 & 35 & 24,50 & $27,10(8,70)$ \\
4 - Integração ensino-serviço & 3 & 15 & 10,50 & $12,70(3,00)$ \\
5 - Presença do estudante no campo de prática & 9 & 45 & 31,50 & $33,70(12,50)$ \\
\hline
\end{tabular}

A comparação entre as médias de respostas de homens e mulheres não revelou diferenças significativas de percepção sobre a preceptoria (Tabela 9).

Tabela 9 - Comparação das médias dos fatores por sexo

\begin{tabular}{|c|c|c|c|c|}
\hline \multirow[b]{2}{*}{ Fator } & \multirow[b]{2}{*}{$\begin{array}{c}\text { Média do } \\
\text { escore }\end{array}$} & \multicolumn{2}{|c|}{ Sexo } & \multirow[b]{2}{*}{$p^{*}$} \\
\hline & & $\begin{array}{c}\text { Feminino } \\
\text { Média (DP) }\end{array}$ & $\begin{array}{l}\text { Masculino } \\
\text { Média (DP) }\end{array}$ & \\
\hline 1 - Competência pedagógica & 35,00 & $43,50(0,96)$ & $43,70(0,89)$ & 0,253 \\
\hline 2 - Suporte e recursos educacionais & 21,00 & $20,10(1,40)$ & $20,50(1,37)$ & 0,207 \\
\hline 3 - Planejamento do programa educacional & 24,50 & $26,90(1,25)$ & $27,40(1,23)$ & 0,167 \\
\hline 4 - Integração ensino-serviço & 10,50 & $12,70(1,00)$ & $17,80(1,06)$ & 0,369 \\
\hline 5 - Presença do estudante no campo de prática & 31,50 & $33,57(1,39)$ & $34,11(1,39)$ & 0,213 \\
\hline
\end{tabular}

Com relação à região do país, a Tabela 10 demonstra que houve diferença significativa entre as percepções dos preceptores nos fatores relativos a "Competência pedagógica", "Planejamento e programa educacional" e "Presença do estudante no campo de prática". 
No fator 1 - "Competência pedagógica", todas as percepções ficaram com média acima do escore médio $(35,00)$, podendo ser considerado que todas as regiões tiveram percepções positivas. A região nordeste foi a que apresentou a média mais alta $(44,60)$, indicando que os preceptores desta região tenderam a uma percepção mais positiva do que os preceptores da região sudeste, com média mais baixa $(42,10)$.

No que se refere ao "Planejamento do programa educacional" - fator 3 e "Presença do estudante no campo de prática" - fator 5, a região nordeste apresentou médias mais altas 28,10 e 35,30 respectivamente, enquanto a região sudeste ficou com as menores médias de respostas 24,60 e 31,70.

Tabela 10 - Comparação das médias dos fatores por região

\begin{tabular}{|c|c|c|c|c|c|c|c|}
\hline \multirow[b]{2}{*}{ Fator } & \multirow[b]{2}{*}{$\begin{array}{c}\text { Média } \\
\text { do } \\
\text { escore }\end{array}$} & \multicolumn{5}{|c|}{ Região } & \multirow[b]{2}{*}{$p^{*}$} \\
\hline & & $\begin{array}{c}\text { Nordeste } \\
\text { Média } \\
\text { (DP) }\end{array}$ & $\begin{array}{l}\text { Norte } \\
\text { Média } \\
(\mathrm{DP})\end{array}$ & $\begin{array}{c}\text { Centro- } \\
\text { Oeste } \\
\text { Média } \\
\text { (DP) }\end{array}$ & $\begin{array}{c}\text { Sudeste } \\
\text { Média } \\
\text { (DP) }\end{array}$ & $\begin{array}{c}\text { Sul } \\
\text { Média } \\
\text { (DP) }\end{array}$ & \\
\hline 1 - Competência pedagógica & 35,00 & $\begin{array}{l}44,60 \\
(0,90)\end{array}$ & $\begin{array}{r}44,50 \\
(0,842)\end{array}$ & $\begin{array}{l}43,10 \\
(1,01)\end{array}$ & $\begin{array}{l}42,10 \\
(1,05)\end{array}$ & $\begin{array}{l}42,80 \\
(0,91)\end{array}$ & $<0,05$ \\
\hline $\begin{array}{l}2 \text { - Suporte e recursos } \\
\text { educacionais }\end{array}$ & 21,00 & $\begin{array}{l}20,90 \\
(1,39)\end{array}$ & $\begin{array}{l}20,00 \\
(1,41)\end{array}$ & $\begin{array}{l}20,00 \\
(1,45)\end{array}$ & $\begin{array}{l}19,40 \\
(1,38)\end{array}$ & $\begin{array}{l}20,00 \\
(1,31)\end{array}$ & 0,198 \\
\hline $\begin{array}{l}3 \text { - Planejamento do } \\
\text { programa educacional }\end{array}$ & 24,50 & $\begin{array}{l}28,10 \\
(1,19)\end{array}$ & $\begin{array}{l}27,90 \\
(1,16)\end{array}$ & $\begin{array}{l}26,90 \\
(1,28)\end{array}$ & $\begin{array}{l}24,60 \\
(1,38)\end{array}$ & $\begin{array}{l}26,80 \\
(1,22)\end{array}$ & $<0,05$ \\
\hline 4 - Integração ensino-serviço & 10,50 & $\begin{array}{l}12,80 \\
(1,06)\end{array}$ & $\begin{array}{l}12,80 \\
(0,98)\end{array}$ & $\begin{array}{l}12,60 \\
(1,04)\end{array}$ & $\begin{array}{l}12,50 \\
(0,98)\end{array}$ & $\begin{array}{l}12,70 \\
(0,97)\end{array}$ & 0,872 \\
\hline $\begin{array}{l}5 \text { - Presença do estudante no } \\
\text { campo de prática }\end{array}$ & 31,50 & $\begin{array}{l}35,30 \\
(1,35)\end{array}$ & $\begin{array}{l}33,40 \\
(1,40)\end{array}$ & $\begin{array}{l}33,80 \\
(1,36)\end{array}$ & $\begin{array}{l}31,70 \\
(1,41)\end{array}$ & $\begin{array}{l}33,30 \\
(1,39)\end{array}$ & $<0,05$ \\
\hline
\end{tabular}

As percepções dos respondentes das diferentes profissões também foram analisadas e evidenciaram diferença significativa nos fatores 1, 2 e 3. Entre as 
profissões, as menores médias foram observadas entre os farmacêuticos (Tabela 11).

Com relação à "Competência pedagógica" (fator 1), cujo escore médio foi 35,00 , os preceptores de todas as profissões tenderam a uma percepção positiva, sendo que os assistentes sociais apresentaram a maior média $(46,30)$.

No fator 2, apenas duas categorias profissionais apresentaram médias acima do escore médio do fator, sendo psicologia com média de 21,40 e a odontologia de 22,80, o que indica que estes profissionais percebem suporte e recursos educacionais no cenário da preceptoria de uma maneira mais positiva.

No fator 3, que fazia referência ao "Planejamento do programa educacional" a odontologia teve o escore mais alto $(28,80)$.

Tabela 11 - Comparação das médias dos fatores por curso de graduação

\begin{tabular}{|c|c|c|c|c|c|c|c|c|c|c|}
\hline \multirow{2}{*}{ Fator } & Média & Enf & Med & Fisiot & Ser So & Psic & Farm & Odont & Outras & \multirow[b]{2}{*}{$p^{*}$} \\
\hline & $\begin{array}{c}\text { do } \\
\text { escore }\end{array}$ & $\begin{array}{l}\text { Média } \\
\text { (DP) }\end{array}$ & $\begin{array}{l}\text { Média } \\
\text { (DP) }\end{array}$ & $\begin{array}{l}\text { Média } \\
\text { (DP) }\end{array}$ & $\begin{array}{l}\text { Média } \\
\text { (DP) }\end{array}$ & $\begin{array}{c}\text { Média } \\
\text { (DP) }\end{array}$ & $\begin{array}{l}\text { Média } \\
\text { (DP) }\end{array}$ & $\begin{array}{l}\text { Média } \\
\text { (DP) }\end{array}$ & $\begin{array}{c}\text { Média } \\
\text { (DP) }\end{array}$ & \\
\hline $\begin{array}{l}\text { 1-Competência } \\
\text { pedagógica }\end{array}$ & 35,00 & $\begin{array}{l}43,30 \\
(0,97)\end{array}$ & $\begin{array}{l}42,90 \\
(0,98)\end{array}$ & $\begin{array}{l}44,40 \\
(0,85)\end{array}$ & $\begin{array}{l}46,30 \\
(0,73)\end{array}$ & $\begin{array}{l}43,50 \\
(0,92)\end{array}$ & $\begin{array}{l}41,90 \\
(1,07)\end{array}$ & $\begin{array}{l}44,10 \\
(0,87)\end{array}$ & $\begin{array}{l}43,10 \\
(0,94)\end{array}$ & $<0,05$ \\
\hline $\begin{array}{l}2 \text { - Suporte e recursos } \\
\text { educacionais }\end{array}$ & 21,00 & $\begin{array}{l}19,90 \\
(1,39)\end{array}$ & $\begin{array}{l}18,40 \\
(1,51)\end{array}$ & $\begin{array}{l}20,64 \\
(1,37)\end{array}$ & $\begin{array}{l}21,00 \\
(1,43)\end{array}$ & $\begin{array}{l}21,40 \\
(1,26)\end{array}$ & $\begin{array}{l}16,60 \\
(1,45)\end{array}$ & $\begin{array}{l}22,80 \\
(1,19)\end{array}$ & $\begin{array}{l}20,60 \\
(1,36)\end{array}$ & $<0,05$ \\
\hline $\begin{array}{l}3 \text { - Planejamento do } \\
\text { programa educacional }\end{array}$ & 24,50 & $\begin{array}{l}27,00 \\
(1,27)\end{array}$ & $\begin{array}{l}27,40 \\
(1,25)\end{array}$ & $\begin{array}{l}28,00 \\
(1,19)\end{array}$ & $\begin{array}{l}27,30 \\
(1,13)\end{array}$ & $\begin{array}{l}28,00 \\
(1,12)\end{array}$ & $\begin{array}{l}24,50 \\
(1,47)\end{array}$ & $\begin{array}{l}28,80 \\
(1,08)\end{array}$ & $\begin{array}{l}25,90 \\
(1,17)\end{array}$ & $<0,05$ \\
\hline $\begin{array}{l}4 \text { - Integração ensino- } \\
\text { serviço }\end{array}$ & 10,50 & $\begin{array}{l}13,00 \\
(0,99)\end{array}$ & $\begin{array}{l}12,50 \\
(1,08)\end{array}$ & $\begin{array}{l}12,75 \\
(0,88)\end{array}$ & $\begin{array}{l}13,20 \\
(0,99)\end{array}$ & $\begin{array}{l}12,60 \\
(0,94)\end{array}$ & $\begin{array}{l}12,40 \\
(1,20)\end{array}$ & $\begin{array}{l}13,30 \\
(0,84)\end{array}$ & $\begin{array}{l}12,00 \\
(1,14)\end{array}$ & 0,062 \\
\hline $\begin{array}{l}5 \text { - Presença do } \\
\text { estudante no campo de } \\
\text { prática }\end{array}$ & 31,50 & $\begin{array}{l}34,10 \\
(1,35)\end{array}$ & $\begin{array}{l}33,60 \\
(1,47)\end{array}$ & $\begin{array}{l}34,29 \\
(1,38)\end{array}$ & $\begin{array}{l}34,10 \\
(1,46)\end{array}$ & $\begin{array}{l}33,50 \\
(1,36)\end{array}$ & $\begin{array}{l}32,60 \\
(1,49)\end{array}$ & $\begin{array}{l}34,30 \\
(1,37)\end{array}$ & $\begin{array}{l}33,10 \\
(1,35)\end{array}$ & 0,786 \\
\hline
\end{tabular}


$\mathrm{Na}$ análise dos fatores e acordo com titulação dos respondentes mostrou diferença estatisticamente significativa somente no fator 1 relativo à "Competência pedagógica". Preceptores com titulação de mestre obtiveram médias mais altas $(44,20)$ e aqueles com titulação de doutorado as mais baixas $(41,00)$ (Tabela 12).

Tabela 12 - Comparação das médias dos fatores por titulação

\begin{tabular}{lcccccc}
\hline \multicolumn{1}{c}{ Fator } & $\begin{array}{c}\text { Média } \\
\text { do } \\
\text { escore }\end{array}$ & $\begin{array}{c}\text { Especialização } \\
\text { Média (DP) }\end{array}$ & $\begin{array}{c}\text { Residência } \\
\text { Média (DP) }\end{array}$ & $\begin{array}{c}\text { Mestrado } \\
\text { Média (DP) }\end{array}$ & $\begin{array}{c}\text { Doutorado } \\
\text { Média (DP) }\end{array}$ & $p^{*}$ \\
\hline $\begin{array}{l}\text { 1- Competência } \\
\text { pedagógica }\end{array}$ & 35,00 & $43,60(0,93)$ & $42,50(1,02)$ & $44,20(0,88)$ & $41,00(1,28)$ & $<0,05$ \\
$\begin{array}{l}\text { 2- Suporte e recursos } \\
\text { educacionais }\end{array}$ & 21,00 & $20,30(1,39)$ & $18,70(1,43)$ & $20,60(1,35)$ & $18,70(1,54)$ & 0,071 \\
$\begin{array}{l}3-\text { Planejamento do } \\
\text { programa educacional } \\
4-\text { Integração ensino- }\end{array}$ & 24,50 & $26,90(1,24)$ & $26,90(1,26)$ & $27,90(1,98)$ & $26,50(1,47)$ & 0,309 \\
$\begin{array}{l}\text { serviço } \\
\text { 5- Presença do }\end{array}$ & 10,50 & $12,70(0,99)$ & $12,20(1,85)$ & $12,80(0,98)$ & $12,60(1,22)$ & 0,572 \\
$\begin{array}{l}\text { estudante em campo } \\
\text { de prática }\end{array}$ & 31,50 & $33,70(1,37)$ & $34,60(1,46)$ & $33,50(1,42)$ & $33,30(1,48)$ & 0,740 \\
\hline
\end{tabular}

${ }^{*}$ ANOVA.

A Tabela 13 apresenta os valores encontrados diante da comparação entre as respostas conforme área de atuação, tendo sido consideradas quatro opções: atuação exclusiva em assistência, em gestão ou em educação, ou atuação em duas ou mais áreas simultaneamente. A análise destes resultados demonstrou diferenças significativas de valor nos fatores 1, 2 e 3.

Os preceptores que atuavam somente na assistência apresentaram a menor média de respostas no que diz respeito a "Competência pedagógica" 
$(42,60)$, "Suporte e recursos educacionais" $(18,90)$ e "Planejamento do programa educacional" $(26,10)$, apesar de ser ainda uma percepção considerada positiva por estar acima da média do escore $(35,00)$.

Tabela 13 - Comparação das médias dos fatores por área de atuação

\begin{tabular}{|c|c|c|c|c|c|c|}
\hline Fator & $\begin{array}{l}\text { Média } \\
\text { do } \\
\text { escore }\end{array}$ & $\begin{array}{c}\text { Atuam } \\
\text { apenas na } \\
\text { Assistência } \\
\text { Média (DP) }\end{array}$ & $\begin{array}{c}\text { Atuam } \\
\text { apenas na } \\
\text { Gestão } \\
\text { Média (DP) }\end{array}$ & $\begin{array}{c}\text { Atuam } \\
\text { apenas na } \\
\text { Educação } \\
\text { Média (DP) }\end{array}$ & $\begin{array}{l}\text { Atuam em } \\
\text { duas ou } \\
\text { mais áreas } \\
\text { Média (DP) }\end{array}$ & $p^{*}$ \\
\hline 1 - Competência pedagógica & 35,00 & $42,60(1,01)$ & $44,00(0,88)$ & $43,20(0,99)$ & $44,60(0,86)$ & $<0,05$ \\
\hline $\begin{array}{l}2 \text { - Suporte e recursos } \\
\text { educacionais }\end{array}$ & 21,00 & $18,90(1,41)$ & $21,20(1,34)$ & $22,50(1,20)$ & $20,30(1,42)$ & $<0,05$ \\
\hline $\begin{array}{l}3 \text { - Planejamento do } \\
\text { programa educacional }\end{array}$ & 24,50 & $26,10(1,313)$ & $27,20(1,68)$ & $27,50(1,2)$ & $28,20(1,20)$ & $<0,05$ \\
\hline 4 - Integração ensino-serviço & 10,50 & $12,60(0,987)$ & $12,90(0,99)$ & $12,20(1,17)$ & $13,00(0,96)$ & 0,095 \\
\hline $\begin{array}{l}5 \text { - Presença do estudante } \\
\text { em campo de prática }\end{array}$ & 31,50 & $33,44(1,413)$ & $32,70(1,40)$ & $34,30(1,34)$ & $34,30(1,37)$ & 0,091 \\
\hline
\end{tabular}

${ }^{*}$ ANOVA.

\subsection{Análise qualitativa da percepção dos preceptores acerca da preceptoria}

A análise qualitativa das questões abertas do questionário utilizado neste estudo: "O que é preceptoria?" e "Qual é a sua percepção do papel social desempenhado pelo preceptor?' revelou quatro e três categorias, respectivamente. Desta forma elucidando a interpretação dos dados coletados e analisados quantitativamente. 
Da análise qualitativa da pergunta "O que é preceptoria?", emergiram as seguintes categorias: Articulação ensino-serviço, Ensino em campo de prática, e Design de currículo (Tabela 14).

Tabela 14 - Análise qualitativa das respostas à pergunta "O que é preceptoria?"

\begin{tabular}{|c|c|c|}
\hline Categoria & Item & Exemplo de discurso \\
\hline $\begin{array}{c}\text { Articulação } \\
\text { ensino-serviço }\end{array}$ & Corresponsabilização & $\begin{array}{l}\text { "Processo de ensino-aprendizagem integrando o educando } \\
\text { a equipe de saúde, que passam a ser corresponsáveis pela } \\
\text { formação". (Psicóloga) } \\
\text { "Um trabalho junto aos estudantes, articulando ensino- } \\
\text { serviço, o qual auxilia na formação profissional". } \\
\text { (Educadora física) }\end{array}$ \\
\hline $\begin{array}{l}\text { Ensino em } \\
\text { campo de }\end{array}$ & Mediação & $\begin{array}{l}\text { "Atividade exercida pelo profissional que está atuando no } \\
\text { serviço, de acolher, acompanhar, estimular e avaliar os } \\
\text { alunos em processo de aprendizagem, fornecendo } \\
\text { subsídios para a formação em campos de prática". } \\
\text { (Nutricionista) }\end{array}$ \\
\hline & $\begin{array}{l}\text { Desenvolvimento de } \\
\text { autonomia }\end{array}$ & $\begin{array}{l}\text { "Processo de mediação do conhecimento por meio do } \\
\text { diálogo com ênfase para a autonomia dos sujeitos". } \\
\text { (Enfermeira) }\end{array}$ \\
\hline \multirow{4}{*}{$\begin{array}{l}\text { Design de } \\
\text { currículo }\end{array}$} & Método de aprendizagem & $\begin{array}{l}\text { "É o ato de acompanhar alunos em campo de estágio } \\
\text { utilizando métodos ativos". (Médico) }\end{array}$ \\
\hline & $\begin{array}{l}\text { Planejamento } \\
\text { educacional }\end{array}$ & $\begin{array}{l}\text { "Atividades que englobam a elaboração conjunta de um } \\
\text { plano/estratégia de ensino no estágio, métodos de } \\
\text { aprendizagem, desenvolvimento de competências no aluno, } \\
\text { avaliação e feedback". (Enfermeira) } \\
\text { "Consiste na criação de ambiente de aprendizagem, de } \\
\text { acordo com as Diretrizes Curriculares Nacionais e } \\
\text { necessidades de saúde da população". (Assistente Social) }\end{array}$ \\
\hline & Formador de visão crítica & $\begin{array}{l}\text { "É auxiliar o aluno nos campos de prática, procurando } \\
\text { desenvolver a capacidade de refletir e interagir com a } \\
\text { realidade". (Farmacêutica) }\end{array}$ \\
\hline & Construção de saberes & $\begin{array}{l}\text { "Relação entre o profissional que atua no serviço de saúde } \\
\text { e o estudante, que contribui para a construção de } \\
\text { conhecimentos e valores que beneficiam o paciente e às } \\
\text { partes envolvidas". (Fisioterapeuta) }\end{array}$ \\
\hline
\end{tabular}


Os participantes do estudo entendem a preceptoria como uma atividade educacional em campo de prática, que utiliza métodos ativos de ensinoaprendizagem na formação de profissionais de saúde, auxiliando-os na melhor compreensão do processo de adoecimento e das necessidades de saúde da população. Neste contexto, a preceptoria é considerada como uma ponte entre o sistema de saúde e a academia. Quando os estudantes estão no cenário de prática, eles interagem com a equipe do serviço, que também se torna responsável pela experiência de aprendizagem.

Os preceptores acreditam que o aprendizado na prática proporciona autonomia aos estudantes e desenvolve sua visão crítica, promovendo assim a habilidade de entender e transformar a realidade da comunidade.

$\mathrm{Na}$ análise da questão "Qual é a sua percepção do papel social desempenhado pelo preceptor?', as categorias que emergiram foram: Educador, Integrador da teoria com a prática e Compromisso. As categorias, itens e exemplos de discurso relacionados a esta questão estão demonstrados na Tabela 15.

Tabela 15 - Análise qualitativa das respostas à pergunta "Qual é a sua percepção do papel social desempenhado pelo preceptor?"

\begin{tabular}{|c|c|c|}
\hline Categoria & Item & Exemplo de discurso \\
\hline \multirow{4}{*}{ Educador } & \multirow{3}{*}{ Modelo } & $\begin{array}{l}\text { "O preceptor é modelo para o desenvolvimento e } \\
\text { crescimento pessoal". (Enfermeira) }\end{array}$ \\
\hline & & $\begin{array}{l}\text { "Influenciar positivamente na formação dos futuros } \\
\text { profissionais, envolvendo-os num processo }\end{array}$ \\
\hline & & participativo, ético e humanizado”. (Assistente Social) \\
\hline & Tutor & $\begin{array}{l}\text { "Papel de orientador, mentor, supervisor e tutor". } \\
\text { (Enfermeira) }\end{array}$ \\
\hline
\end{tabular}


Continuação

\begin{tabular}{cll}
\hline & & "Estimula a integração entre equipe, comunidade e \\
Integrador da & instituição de ensino". (Dentista) \\
teoria com a & "Pregração & "Preceptor auxilia aos educandos na identificação das \\
prática & necessidades de saúde da população, nos cenários de \\
& prática, de modo que ele direcione seu aprendizado". \\
& (Farmacêutico) \\
\hline & "Desenvolver atividades pedagógicas que consigam \\
& tornar o aluno crítico e reflexivo, reconhecendo a sua \\
& potência como transformador de uma realidade social". \\
& (Médica) \\
& "Responsabilidade que vai além de uma formação \\
& específica, para uma formação como indivíduo, como \\
& sujeito transformador da realidade". (Enfermeira \\
\hline
\end{tabular}

Conclusão

Os preceptores reconhecem seu papel e responsabilidades na formação de um outro profissional, que acompanha a sua prática. Percebem-se como modelo profissional que favorece o desenvolvimento de competência técnica, emocional e moral, e do compromisso profissional com a transformação da realidade na qual estão inseridos e promoção da qualidade de vida da população. O papel social do preceptor é inerente as diferentes dimensões da sua atuação, como nos revelam os discursos:

"O preceptor é modelo para o desenvolvimento e crescimento pessoal". "Papel de orientador, mentor, supervisor e tutor". 


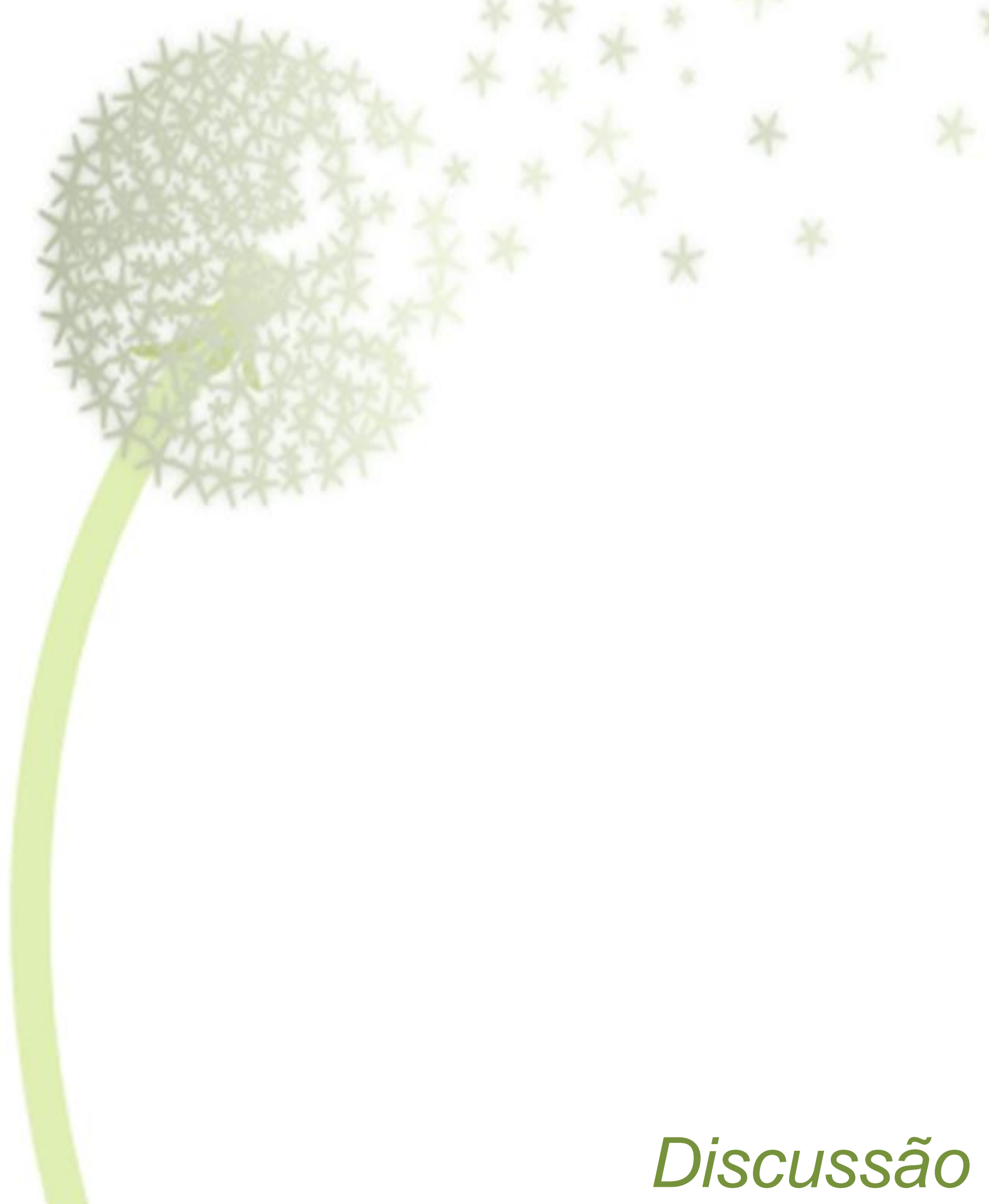




\section{Discussão}

A Lei $n^{0} 12.871$, de $2013^{44}$, valorizou a preceptoria na formação dos médicos, o que estimulou a oferta de diversos processos de capacitação e especialização para preceptores ${ }^{75,85,86}$. Apesar da inegável contribuição destes processos de formação de preceptores para a transformação da realidade da preceptoria no Brasil, ainda são poucas as publicações e análises científicas acerca deste tema. Neste sentido, o presente estudo responde a uma demanda de produção científica da área.

A coleta de dados descentralizada foi um fator de dificuldade no que tange a adesão dos participantes. A capacitação dos responsáveis pela coleta e a elaboração de um protocolo de coleta não foram suficientes para garantir a participação das 20 cidades onde o curso foi ministrado. Quando analisada a adesão ao estudo em cada uma as cinco regiões do país, observou-se que ela variou entre $32,60 \%$ a $67,60 \%$, o que caracteriza esta amostra como de conveniência, como a totalidade dos artigos levantados neste estudo.

Pode-se dizer que os dados aqui apresentados são representativos da população de preceptores que concluíram o curso de especialização em Educação na Saúde para Preceptores o SUS no ano de 2014, no entanto, não é possível generalizar os resultados para todos os preceptores do Brasil, por tratar-se de uma amostra de conveniência. Apesar disso, houve variações nas características dos indivíduos nesta amostra, que sugerem uma abrangência relativa aos contextos diversos da preceptoria no Brasil.

A caracterização da amostra sinalizou maioria de mulheres $(80,70 \%)$ e de profissionais graduados em enfermagem (35,20\%), resultado que se repetiu na 
análise isolada dos respondentes de cada uma das regiões do país. Este dado reflete o fenômeno de feminização nas profissões da saúde, presente no Brasil e no mundo ${ }^{87,88}$

Com relação à titulação, apenas $6,40 \%$ dos participantes afirmaram ter concluído curso de especialização na modalidade residência, dado que indica que a maioria dos participantes não teve a oportunidade de conviver com um preceptor durante sua formação de pós-graduação. Os profissionais que afirmaram ter feito residência eram médicos ou enfermeiros, o que demonstra que em outras áreas da saúde, o processo de especialização por meio da residência ainda é incipiente, apesar do estímulo dado com a criação da residência multiprofissional em saúde, a partir da promulgação da Lei $\mathrm{n}^{\circ}$ 11.129 , em $2005^{89}$. A residência na área médica é considerada padrão ouro de especialização ${ }^{90}$, o que corrobora o achado neste estudo, de que, entre os que afirmaram ter residência, 66,67\% eram médicos.

A preceptoria na área de saúde no Brasil passou a ser discutida e implementada mais amplamente a partir de 2001, com a homologação das DCN para os cursos de graduação na saúde ${ }^{91,92}$.

A idade média dos participantes deste estudo (37,7 anos) permite inferir que a maioria deles não tenha vivenciado a relação preceptor-aluno, ou que esta vivência tenha sido incipiente, pois o processo de transformação dos cursos da saúde se estendeu por, pelo menos, dez anos ${ }^{46,93}$.

Dentre os participantes, a maioria atuava na assistência (64,50\%), o que confirma a natureza da preceptoria como modalidade de formação em campo de prática. No entanto, os participantes do estudo afirmaram, também, atuar na área de educação e gestão, ou em mais de uma área, demonstrando que a 
prática da preceptoria congrega as áreas de gestão, educação e assistência, como a literatura conceitua ${ }^{19,75,86}$.

As respostas dos participantes sobre "O que é preceptoria", podem ser sintetizadas trazendo-a como uma atividade que se traduz na relação de aprendizado entre preceptor e aluno, que se dá em campo de prática, por meio de métodos ativos de ensino-aprendizagem e que busca desenvolver a capacidade de refletir para interagir com a realidade.

Ao analisar a opinião dos participantes sobre qual seria o papel do preceptor, foi evidenciado o papel de orientador do aprendizado, de maneira que sejam formados profissionais críticos-reflexivos e potenciais transformadores da realidade através da ação-reflexão-ação.

Esta relação de aprendizagem citada pelos respondentes diz respeito à formação de adultos, portanto, reafirma a necessidade de que os profissionais que atuam como preceptores conheçam e apliquem em sua prática os princípios da Teoria da Aprendizagem de Adultos. A andragogia considera os conhecimentos prévios do educando, necessidade de motivação para o aprendizado, contextualização das informações a serem apreendidas, aplicabilidade do conhecimento, necessidade de feedback ao longo do processo, respeito à autonomia do educando, compartilhamento das experiências $^{94}$.

Esta relação horizontal entre educador e educando, favorece o desenvolvimento do olhar crítico do educando e autonomia frente à realidade ${ }^{35}$. Pode-se entender também que é papel do preceptor auxiliar o aluno na atribuição de significado ao conhecimento novo que está sendo proposto, o que favorece sua mobilização para aprender e aplicar os novos conhecimentos ${ }^{95}$. 
A análise das respostas dos participantes deste estudo acerca do que é preceptoria traz ainda o enfoque da natureza prática desta atividade, que propicia o uso de métodos ativos como a problematização. A problematização, é um método ativo de ensino-aprendizagem, à medida que coloca o aluno como centro do processo e sujeito ativo na produção de seu conhecimento. Trata-se de um método potente na formação de adultos, proporcionando que problemas reais vivenciados sejam colocados para reflexão e ressignificação. Desta maneira, o aluno, após o processo de aprendizagem retorna à realidade com maior capacidade para transforma-la ${ }^{96,97}$. Neste processo de reflexão e ressignificação é que o educando toma consciência sobre os fatos vivenciados e toma a decisões para atuar sobre eles.

Para Paulo Freire ${ }^{97}$ a condição primeira para transformar a realidade é o desenvolvimento de uma consciência crítica. Existem dois tipos de consciência, sendo uma crítica e a outra ingênua. Quando ocorre compreensão dos fatos e internalização do conhecimento, é possível dizer que se desenvolveu a consciência crítica, uma vez que a recorrência dos fatos irá gerar análise e avaliação sobre a autenticidade, trata-se da consciência de que não há verdade absoluta e é necessário analisar cada situação. Já a consciência ingênua considera o conhecimento como estático e não pressupõe análise da autenticidade da informação. É a criticidade que deve ser estimulada ao educar, garantindo o que os sujeitos tenham autonomia para produzir seu conhecimento e sejam capazes de realizar a análise da autenticidade da informação.

À capacidade de desenvolvimento de consciência crítica e reconhecimento da aplicabilidade do conhecimento adquirido, que por sua vez 
possibilitará um movimento de ação-reflexão-ação, também entendido como metacognição, atribui-se a possibilidade de transformação da realidade por meio da educação. As técnicas de ensino-aprendizagem que trabalham com a metacognição preconizam a aprendizagem significativa, a auto-avaliação e a reflexão sobre o aprendizado. As estratégias para desenvolver atividades metacognitivas não são genéricas, ou seja, devem ser adaptadas e recriadas a cada situação, buscando aumentar a possibilidade e transferência do aprendizado a novos cenários e desenvolver competência, visando independência e auto-gestão do aprendizado ${ }^{73}$.

Botti $^{19}$ afirma que a capacidade de refletir, "analisar e avaliar" as vivências é essencial ao processo de aprendizagem. Este autor explica que a reflexão pressupõe dois momentos: inicialmente o indivíduo faz uma análise sobre maneira como executa as ações, em seguida, avalia o grau de qualidade com que executa tais ações. A capacidade de refletir pressupõe que 0 profissional esteja em constante avaliação, sempre buscando aprender melhores ferramentas para executar as ações e qualificando sua prática.

A metacognição atende as demandas de aprendizado e aplicação do conhecimento para qualificação das ações em diferentes níveis, em um conexto de mundo que vem sofrendo mudanças consideráveis, no qual a necessidade de conhecimento adquire um ritmo muito acelerado, exigindo a formação de pessoas que aprendam a buscar informações e construir seu conhecimento no momento em que for necessário, ao invés de apenas memorizar e repetir informações. 
A análise das questões abertas do questionário reforça a percepção positiva dos preceptores acerca das afirmativas que compõem o Fator 1 "Competência pedagógica".

Competência pode ser entendida como a capacidade de mobilizar um conjunto de recursos integrados (conhecimento, habilidades e atitudes) para enfrentar situações diversas e complexas e desenvolver respostas a situaçõesproblema $^{98}$.

Harden e Crosby $^{99}$ descreveram a competência pedagógica em seis áreas de atuação docente: 1. Provedor de informações; 2. Modelo profissional; 3. Facilitador do aprendizado; 4. Avaliador do currículo; 5. Gestor educacional e 6. Desenvolvedor de material didático. Como Provedor de Informações, o professor precisa estar atualizado na sua área de atuação profissional e saber como compartilhar seus conhecimentos e experiência. Ele será Modelo de atuação profissional quando observado em sua prática e em sua forma de atuar no processo de ensino aprendizado. O professor é um Facilitador do processo de ensino aprendizado quando apoia os estudantes nas diferentes atividades educacionais. No papel de Avaliador, o professor se responsabiliza pela avaliação do desempenho dos estudantes. Já como Gestor, ele fará o planejamento educacional e a implementação do currículo, ou seja, fará com que o currículo declarado se concretize no currículo vivido. Finalmente como Desenvolvedor de material didático o professor deve prover recursos didáticos que apoiem as atividades.

Os participantes afirmam que se sentem aptos para desenvolver atividades de ensino junto aos estudantes, o que aponta segurança para atuarem na formação de profissionais. Trata-se de uma afirmação de conceito global, sem 
discriminar os seis domínios descritos por Harden ${ }^{48}$. Talvez se fossem questionados os domínios isoladamente, seriam constatados diferentes níveis de segurança em cada um deles.

Coates e Gormley ${ }^{26}$ desenvolveram um estudo buscando analisar a visão dos preceptores sobre seu papel no processo de ensino-aprendizagem dos estudantes e os resultados mostraram que os preceptores se consideram melhor preparados para serem role models do que para atuarem como professores da prática clínica. As principais habilidades do bom preceptor, elencadas pelos próprios preceptores deste estudo, foram: conhecimento, experiência, ser acessível e ter boa comunicação. As principais barreiras, na opinião dos preceptores deste mesmo estudo, são a falta de tempo e a carga horária, mais relevantes, inclusive, do que a falta de conhecimento, além da falta de treinamento adequado.

Em relação à necessidade de manter-se atualizado e ter autonomia na busca do conhecimento, no presente estudo, os preceptores afirmam que identificam suas próprias necessidades de aprendizagem e buscam conhecimentos em bases de dados. Outros autores afirmam que preceptores atuam como docentes, orientam frente a situações reais do cuidado, estimulando a visão crítica e autonomia na produção do conhecimento, ao mesmo tempo que se mantêm atualizados em processo de formação ${ }^{30,38,100}$.

Ainda fazendo relação ao fator que trata da competência pedagógica, o preceptor assume papel de modelo junto aos estudantes, é importante que demonstre competência adequada à sua prática profissional e a que se espera dos profissionais que estão sendo formados ${ }^{30,33}$. Um bom desempenho do 
preceptor interfere diretamente no desenvolvimento dos estudantes e do serviço, além de aprimorar o desenvolvimento de seu próprio papel enquanto educador e profissional de saúde ${ }^{101}$. O bom desempenho do preceptor, citado pelos autores parece estar diretamente ligado ao papel de "docente" que desempenha nas "atividades pedagógicas" compreendidas na preceptoria.

A função de supervisionar, muitas vezes atribuída ao preceptor, traduz o acompanhamento do discente em campo, estimulando a "aplicação da teoria na prática", de maneira que conduza o discente à melhores opções com relação às condutas e ao desenvolvimento de habilidades e atitudes ${ }^{19}$. Este acompanhamento prevê avaliação contínua e feedback. Os respondentes consideram que a avaliação do estudante é sua responsabilidade e afirmaram realizar avaliações somativas, ao final do processo de ensino-aprendizado, neste caso da disciplina ou estágio; e formativas, contínuas e frequentes durante todo o processo, e seguidas de devolutiva.

Os participantes também demonstraram concordância quando questionados sobre o interesse em seguir carreira docente, o que indica que, ao se sentirem capacitados, e entender que a preceptoria melhora sua qualidade de vida, sentem-se motivados a prosseguir neste caminho, o de formar pessoas.

Broadbent e colaboradores ${ }^{28}$, evidenciaram a falta de formação específica de preceptores para a atividade educacional, bem como o desconforto por não estarem devidamente formados e a pela falta de clareza quanto ao seu papel. No que diz respeito a esta formação pedagógica para atuar como preceptor, os participantes tiveram opiniões divididas, o que leva a crer que para responder esta afirmativa consideraram sua situação no momento em que começaram a 
atuar como preceptores, antes da realização do curso de capacitação no qual os dados foram coletados. Sendo assim, pode-se dizer que os dados corroboram os trazidos na literatura, já que foi expressivo o número de respostas que indicam percepção negativa no que diz respeito à formação pedagógica para a preceptoria.

Albuquerque et al. ${ }^{102}$ sinalizam que a inserção do aluno no cenário de prática pode trazer foco a uma série de problemas que existem nos serviços, tendo em vista que raramente tem-se disponíveis as condições ideais de trabalho. A vivência no cenário de prática deve proporcionar reflexões, que potencializem a capacidade de transformações positivas na realidade pelos profissionais em formação. Para que isso possa ser colocado em prática, os profissionais e os serviços devem estar abertos para receber os educandos em seu cotidiano, de maneira que entendam a lógica real do trabalho. É essa vivência do real que poderá dar ao profissional que está sendo formado a dimensão das necessidades de saúde da população, além das dificuldades encontradas pelos profissionais do serviço, já que este estes são pontos que podem ficar ocultos durante a apreensão do "conteúdo teórico" pelos educandos.

O Fator 2, relativo a "Suporte e recursos educacionais", reflete a possibilidade de integração ensino-serviço e o consequente reconhecimento da atividade de preceptoria.

Quando propõe-se um currículo integrado, sob o modelo da competência dialógica, o que se espera é exatamente um "diálogo" entre teoria e prática/academia e serviço, onde o apoio teórico ocorre à medida em que as ações são desempenhadas e os problemas aparecem ${ }^{103}$. É exatamente esta 
mediação que se espera do profissional que exerce atividade de preceptoria, integrando conhecimentos teóricos e práticos, buscando romper com a dicotomização que vem ocorrendo nos ambientes de aprendizagem.

Os respondentes apresentaram opiniões divididas no que tange ao reconhecimento de seu trabalho pelos profissionais das IES e à participação de espaços de discussão para integração ensino-serviço. Desafios para proporcionar o diálogo entre a academia e o serviço são também descritos na literatura. Cavalheiro \& Guimarães ${ }^{104}$ descrevem em seu estudo a realização de oficinas que identificam potencialidades e desafios na formação de profissionais para o SUS, por meio da reflexão conjunta entre IES, representadas por gestores, discentes e docentes e Secretaria Municipal de Saúde, representada pelos gestores, trabalhadores e usuários. Neste estudo, após análise dos pontos levantados pelos atores envolvidos, concluem que é necessário investir nas relações entre academia e serviço, de maneira que haja uma integração dos valores e possibilidade de compreensão mútua e decisões compartilhadas.

As IES devem compreender que o serviço não é apenas um local de estágio e sim um local de produção do cuidado e de conhecimentos. O serviço de saúde, por sua vez, deve levar em consideração que o estudante não é força de trabalho e sim um elemento que estimula a equipe de saúde a buscar a melhor forma possível de produção do cuidado e de conhecimento.

Segundo Coates e Gormley ${ }^{26}$, tempo disponível para a atividade de preceptoria é um recurso necessário ao bom desempenho do preceptor. No presente estudo, os preceptores afirmam encontrar apoio de sua chefia para desenvolver as atividades de preceptoria, o que pode ser considerado um 
ponto favorável, uma vez que isto se concretiza em maior flexibilidade e possibilidade de redimensionamento do tempo despendido para esta atividade, em função da presença do estudante.

A análise do Fator 3, relativo ao "Planejamento do programa educacional", demonstra a coerência da atividade de preceptoria com o proposto nas DCN. As DCN propõem a formação profissional em campo de prática, visando a inserção dos alunos na realidade do serviço e, desta maneira, formar profissionais mais preparados para o mundo real do trabalho $^{10,42,91}$. Os respondentes entendem que suas atividades estão de acordo com as DCN e com o proposto na Lei $n^{0} 12.871^{44}$.

Com relação à coparticipação da rede de serviços na formação do estudante, a percepção da maioria dos preceptores foi positiva, o que indica valorização da sua participação, no entanto, quando questionados sobre a inclusão de toda a equipe do seu serviço nesta formação, a percepção foi mais negativa. Diversos autores afirmam que, para que a preceptoria possa atingir seus objetivos educacionais, é preciso que as instituições formadoras e os serviços de saúde se co-responsabilizem pela formação na saúde, nos diferentes níveis e cenários de prática ${ }^{102,105,106}$.

Manyon et al. ${ }^{107}$ ressaltam que o ensino junto à comunidade requer uma visão ampliada do processo de ensinar e que ensinar e aprender ocorrem de maneira colaborativa, conectando preceptor, estudantes, profissionais da assistência e usuários.

Albuquerque et al. ${ }^{102}$ trazem que a articulação ensino-serviço se traduz em uma relação entre docentes da academia, estudantes e equipes que estão 
nos serviços de saúde, visando uma formação profissional voltada à construção de um cuidado à saúde qualificado, além da satisfação das equipes de saúde participantes desta formação. Os preceptores neste estudo afirmam que, através de suas atividades educacionais junto aos estudantes, buscam integrar toda a equipe da unidade de saúde na formação profissional deste indivíduo.

Não houve consenso das respostas no que diz respeito à autonomia dos preceptores para definir propostas educacionais, participação dos preceptores em espaços de discussão ensino-serviço e reconhecimento da atividade de preceptoria pelos profissionais que atuam nas IES, o que demonstra que os respondentes não se consideram completamente inseridos no processo de construção da proposta de ensino na preceptoria. Uma vez que o sistema de saúde não está inserido formalmente nas instituições educacionais e que estas têm autonomia para programação de seus cursos, o que espera-se é que o ensino nestas instituições esteja vinculado ao mundo real do trabalho, tendo em vista a necessidade de formar profissionais que estejam aptos para atuarem neste mundo, ou seja, o que se espera é que as instituições de ensino garantam o cumprimento de seu papel social perante as políticas públicas de saúde ${ }^{12}$.

Os preceptores demonstraram percepção positiva nas questões que indagam sobre a identificação e consideração das necessidades de saúde da população para definição dos objetivos educacionais, além de afirmarem que articulam aspectos biológicos, sociais e culturais do processo saúde-doença para definir as atividades de preceptoria. Isto indica que compreendem a necessidade de formar profissionais voltados à integralidade, de acordo com as 
afirmações do Fator 4 - "Integração ensino-serviço". Isto concorda com o trazido por Ceccim e Feuerwerker ${ }^{12}$ quando interpretam a Constituição Nacional e a Lei de Diretrizes Educacionais Brasileiras e relembram que a devida formação de profissionais, voltada para a atenção integral às necessidades de saúde da população, é dever do sistema de saúde vigente.

Portanto, para estes autores, a formação profissional dita aqui, vai além de formar para a saúde, engloba a formação para o SUS, de maneira que o profissional não tenha como foco apenas a doença e os agravos à saúde individuais e coletivos, mas também o desenvolvimento da autonomia das pessoas, logo, o conhecimento do SUS e seus princípios e diretrizes deve estar incluído na formação, como preconiza a citação a seguir:

A formação para a área da saúde deveria ter como objetivos a transformação das práticas profissionais e da própria organização do trabalho e estruturar-se a partir da problematização do processo de trabalho e sua capacidade de dar acolhimento e cuidado às várias dimensões e necessidades em saúde das pessoas, dos coletivos e das populações. A melhor síntese para esta designação à educação dos profissionais de saúde é a noção de integralidade, pensada tanto no campo da atenção, quanto no campo da gestão de serviços e sistemas $^{61}$.

Com relação à "Presença do estudante no campo de prática", abordada no Fator 5, a presença do estudante pode sobrecarregar as atividades, conforme indicado por $44 \%$ dos participantes, no entanto, a maioria afirma que o ter no serviço é positivo, uma vez que sua presença melhor a qualidade do serviço, não desagrada os usuários e não compromete a segurança do paciente. 
Quando discorre sobre a inserção de residentes às equipes de Saúde da Família, Nascimento ${ }^{108}$ afirma que trata-se de uma relação de troca, onde o residente agrega novas possibilidades de produzir cuidado às rotinas da equipe, estimulando a "renovação do trabalho, enquanto esta equipe se torna corresponsável pela formação dos profissionais residentes, proporcionando a inserção na lógica da realidade do cotidiano do serviço de saúde. É diante desta inserção e sentindo-se como membro da equipe de saúde que o educando tem a possibilidade de compreender e buscar atender integralmente às necessidades da população. O preceptor deve estar preparado para manejar possíveis conflitos decorrentes da presença do estudante dentro da equipe de saúde e junto aos usuários.

Na percepção de 55\% dos participantes, nem toda a equipe de saúde participa da formação do estudante, apesar de terem afirmado em questão anterior que suas atividades de preceptoria buscam integrar a equipe na formação. A co-responsabilização da equipe na formação é essencial para que esta sinta-se participante do processo e acolha melhor o educando, deixando de vê-lo como uma "ameaça ao desempenho de seu trabalho", ou como "mais um trabalho a ser feito em sua rotina"; e passando a entende-lo como um agregador de conhecimentos e potencializador do aprimoramento das práticas.

Os cenários de prática são ambientes com operação do senso de cidadania e consolidação do SUS. Dentro deste contexto, a busca pela valorização do preceptor e seu reconhecimento como docente, bem como sua capacitação para o processo de ensino-aprendizagem são primordiais ${ }^{17,34,39}$ para o sucesso na formação de profissionais no SUS e para o SUS. 


\subsection{Considerações finais}

A preceptoria tem importância central na formação na saúde, à medida que as novas DCN para os cursos de graduação em medicina foram incluídas na Lei $n^{\circ} 12.871$ de 22 de outubro de 2013, que institui o Programa "Mais Médicos"44. Neste contexto, é fundamental compreender a percepção dos profissionais que atuam como preceptores de estudantes de graduação e pósgraduação acerca das práticas pedagógicas articuladas com as práticas de cuidado e do seu papel na formação de trabalhadores para o SUS.

O presente estudo demonstrou pontos fortes: desenho de pesquisa original, abordagem quantitativa e qualitativa e abrangência nacional, tendo a representatividade das cinco regiões do Brasil. Além disso, o instrumento elaborado para a pesquisa poderá ser reproduzido em outros estudos. Este desenho de pesquisa permitiu alcançar os objetivos propostos no início do estudo.

Admite-se como pontos fracos do estudo, ter utilizado amostra de conveniência e com uma coleta de dados ao final de um curso de especialização em educação na saúde. No entanto, os resultados deste estudo contribuem para o entendimento e a discussão das práticas pedagógicas em serviço à medida que oferecem voz aos preceptores para exporem suas percepções acerca da identidade do preceptor, a natureza da preceptoria e as condições do SUS como uma rede escola. 


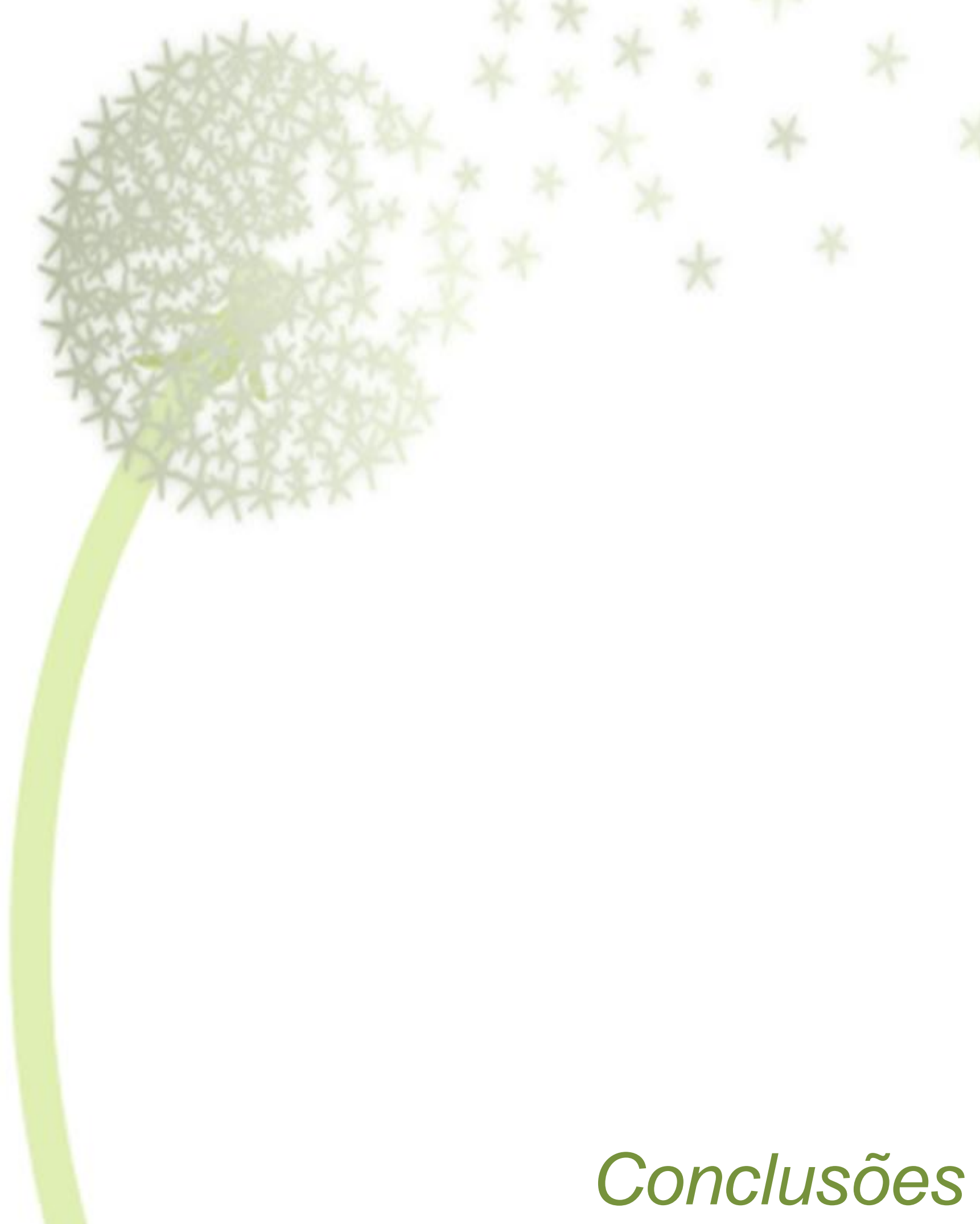




\section{Conclusões}

Os participantes do estudo demonstraram percepção positiva acerca da atividade de preceptoria, tendo clareza do seu papel de formador de outros profissionais no cenário de prática. Eles afirmaram perceber as dificuldades inerentes do processo de integração ensino-serviço, mas também as potencialidades no que tange a formação de profissionais cidadãos, éticos e competentes para atender as necessidades de saúde da população e transformar a realidade em que estão inseridos. $O$ entendimento sobre qual é o papel do preceptor se sobrepõe ao conceito de preceptoria na visão dos participantes.

Os preceptores apontaram que desempenham papel de modelo, tutor, orientador, supervisor e mentor ao desenvolverem suas atividades junto aos alunos.

Entre os respondentes houve um predomínio de mulheres e de profissionais da enfermagem. Quanto a área de atuação a maioria dedicava-se a assistência.

As análises de dados não demonstraram diferença de percepções entre homens e mulheres.

A análise de itens demonstrou percepção negativa acerca da participação da equipe de saúde na formação do aluno e da falta de remuneração específica para a função de preceptor.

$\mathrm{Na}$ análise fatorial, os preceptores do nordeste tiveram a visão mais positiva acerca da preceptoria e suas vicissitudes, e os do sudeste a menos 
positiva. Entre as profissões, os preceptores farmacêuticos apresentaram a pior percepção.

Os preceptores que atuavam somente na assistência apresentaram uma visão mais crítica e negativa nos Fatores 1, 2 e 3, respectivamente de competência pedagógica, suporte e recursos educacionais e planejamento do programa educacional.

Considerando-se a variação de escores mínimos e máximos por fator, o Fator 2, relativo ao suporte e recursos educacionais, foi o único com escore total abaixo da média, revelando percepção menos positivas acerca das afirmações que o fator abrange.

O Fator 4, relativo a integração ensino-serviço, não apresentou diferença de percepção entre os sexos, regiões, profissões, titulação ou área de atuação.

Os preceptores que participaram deste estudo demonstram clareza da natureza da preceptoria e do seu papel de educadores, e reconheceram que sua atividade junto aos alunos atende às diretrizes de formação profissional vigentes no Brasil. As diferenças regionais encontradas demonstram que a preceptoria está em momentos de implantação e aprimoramento diversos e demanda esforços para o desenvolvimento pleno do aprendizado nos cenários de prática do Sistema Único de Saúde. 


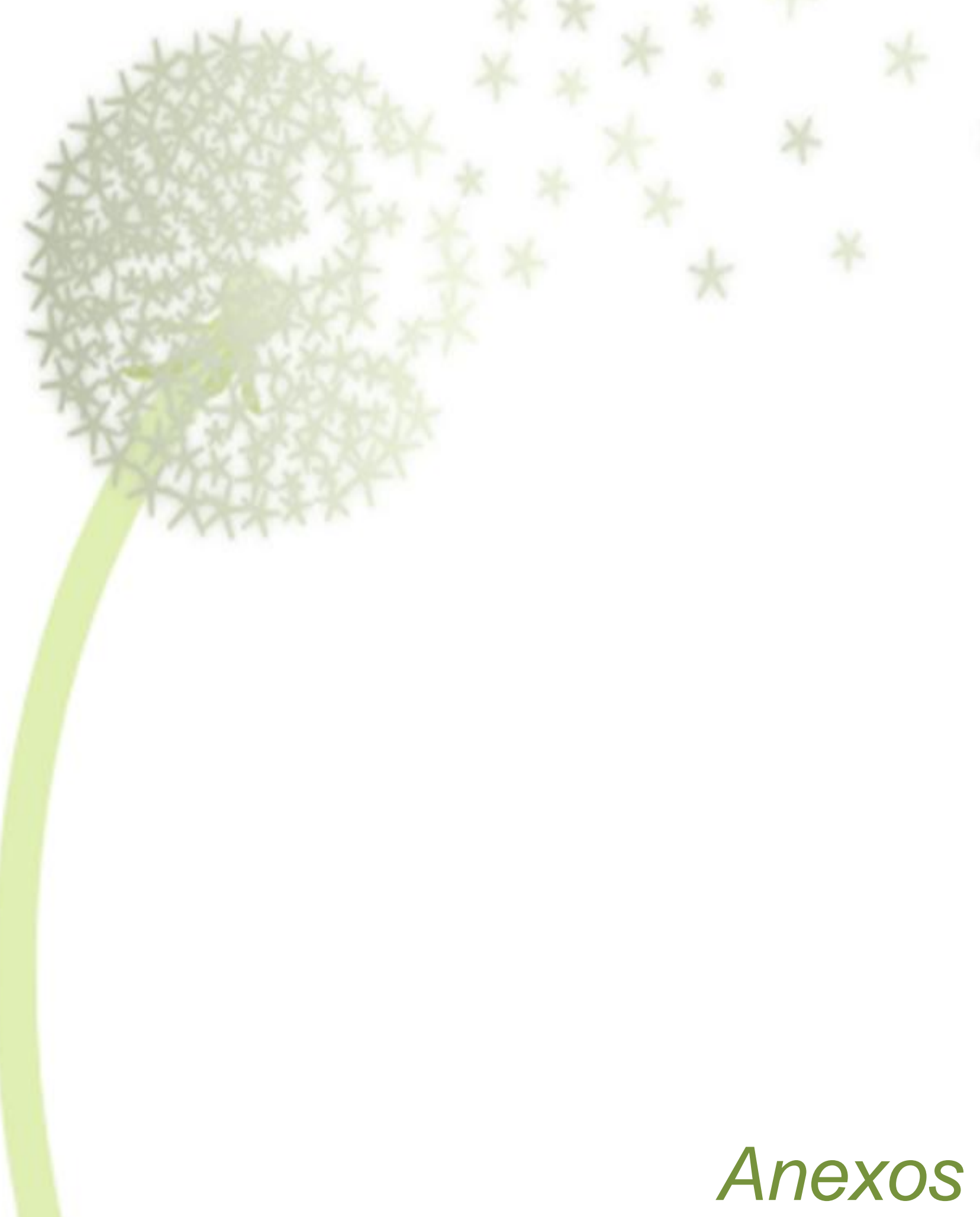




\section{ANEXOS}

Anexo A: Aprovação no Comitê de Ética da Faculdade de Medicina da Universidade de São Paulo

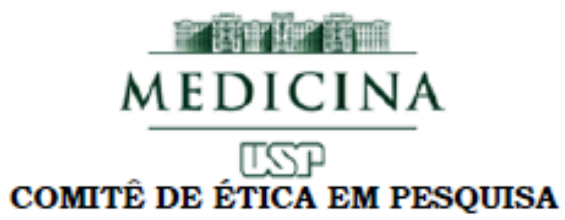

\section{APROVAÇÃO}

O Comitê de Ética em Pesquisa da Faculdade de Medicina da Universidade de São Paulo, em sessão de 05/11/2014, APROVOU o Protocolo de Pesquisa $n^{\circ} 3^{67 / 14}$ intitulado: "PRECEPTORES DO SISTEMA ÚNICO DE SAÚDE: VISÃO DO PROCESSO DE FORMAÇÃO NA SAÚDE E DO SEU PAPEL SOCIAL" apresentado pelo Departamento de Clínica Médica.

Cabe ao pesquisador elaborar e apresentar ao CEPFMUSP, os relatórios parciais e final sobre a pesquisa (Resolução do Conselho Nacional de Saúde $n^{\circ}$ 466/12).

Pesquisador (a) Responsável: Patrícia Zen Tempski Pesquisador (a) Executante: Leticia Cabrini Girotto

CEP-FMUSP, o5 de Novembro de 2014 .

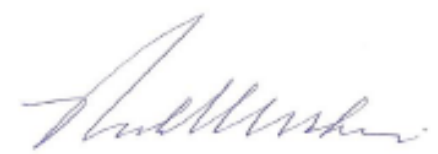

Prof. Dr. Paulo Eurípedes Marchiori

Vice-Coordenador

Comitê de Ética em Pesquisa 


\section{Anexo B: Autorização do IEP/HSL para coleta de dados}

\section{INSTITUTO SÍRIO-LIBANÊS \\ DE ENSINO E PESQUISA}

Ofício Superintendência de ensino no 10/2014

São Paulo, 27 de março de 2014.

Ao

Comitê de Ética da Universidade de São Paulo

Prezados Senhores,

Autorizamos o acesso ao banco de dados do projeto de apoio ao SUS intitulado Curso de Especialização Educação na Saúde para Preceptores no SUS, pelas orientadoras Marilda Siriani e Patrícia Zen Tempski e pela Mestranda Letícia Cabrini Girotto, responsáveis pelo projeto intitulado: Preceptores do SUS: visão do processo de aprendizagem e do papel social, submetido e aprovado pela AVAP - Ambiente Virtual de Apoio à Pesquisa do Hospital Sírio-Libanês.

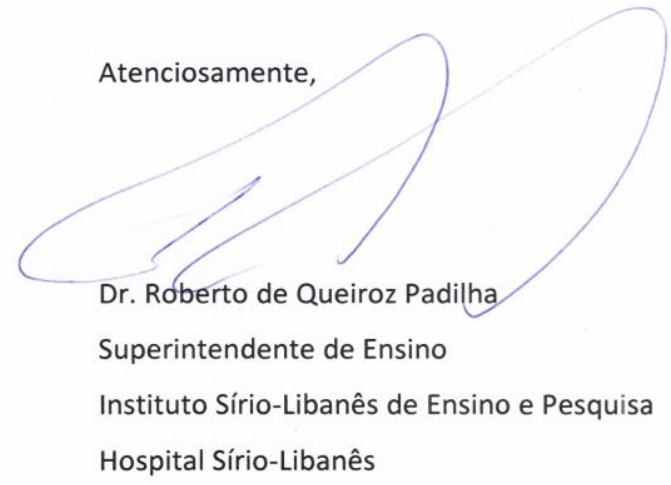


Anexo C: Questionário de Perfil Sócio-demográfico

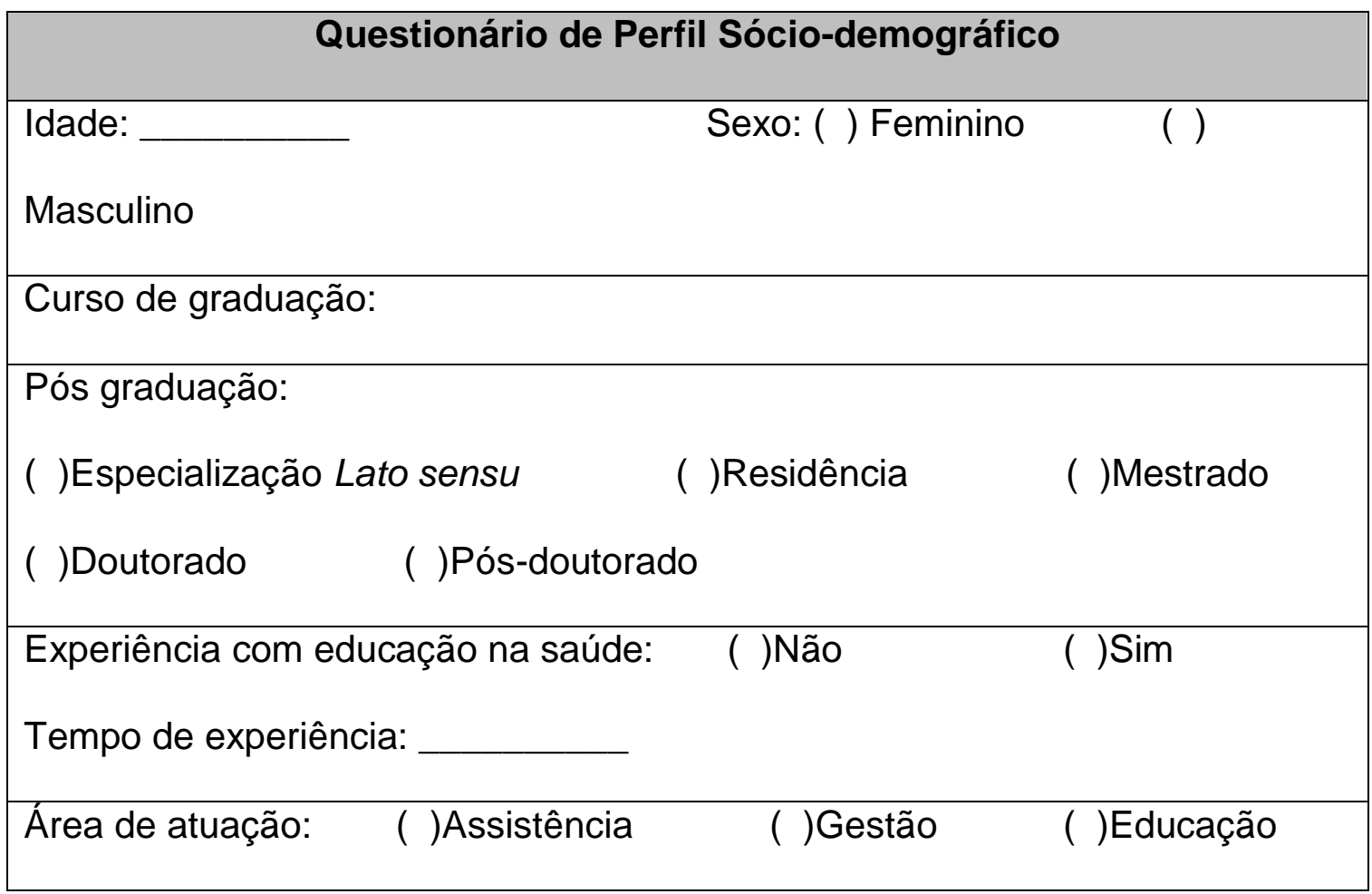


Anexo D: Instrumento de coleta de dados

De acordo com a sua vivência cotidiana, assinale uma das opções, sabendo que: $\mathrm{CT}=\mathrm{CONCORDO}$ TOTALMENTE; $\mathrm{CP}=\mathrm{CONCORDO}$ PARCIALMENTE; I=INDIFERENTE; DP= DISCORDO PARCIALMENTE E DT= DISCORDO TOTALMENTE.

\begin{tabular}{|c|c|c|c|c|c|c|}
\hline \multicolumn{2}{|r|}{ Afirmativa } & CT & CP & I & DP & DT \\
\hline 1 & $\begin{array}{l}\text { A presença do estudante no ambiente de } \\
\text { trabalho sobrecarrega minhas atividades. }\end{array}$ & & & & & \\
\hline 2 & $\begin{array}{l}\text { A presença do estudante desagrada os } \\
\text { usuários. }\end{array}$ & & & & & \\
\hline 3 & $\begin{array}{l}\text { A qualidade do meu serviço melhora com a } \\
\text { presença do estudante. }\end{array}$ & & & & & \\
\hline 4 & $\begin{array}{l}\text { Não tenho autonomia para definir propostas } \\
\text { educacionais. }\end{array}$ & & & & & \\
\hline 5 & $\begin{array}{l}\text { A rede de serviço é co-responsável pela } \\
\text { formação do profissional de saúde. }\end{array}$ & & & & & \\
\hline 6 & $\begin{array}{l}\text { Minhas atividades de preceptoria estão de } \\
\text { acordo com as Diretrizes Curriculares } \\
\text { Nacionais. }\end{array}$ & & & & & \\
\hline 7 & $\begin{array}{l}\text { Tenho os recursos necessários para } \\
\text { desenvolver minhas atividades educacionais. }\end{array}$ & & & & & \\
\hline 8 & $\begin{array}{l}\text { Minha atividade de preceptoria integra o } \\
\text { estudante na equipe de saúde. }\end{array}$ & & & & & \\
\hline 9 & $\begin{array}{l}\text { Recebi formação pedagógica para desenvolver } \\
\text { a preceptoria. }\end{array}$ & & & & & \\
\hline 10 & $\begin{array}{l}\text { Tenho apoio da minha chefia para desenvolver } \\
\text { a preceptoria }\end{array}$ & & & & & \\
\hline 11 & $\begin{array}{l}\text { Sinto-me apto para desenvolver atividades } \\
\text { educacionais. }\end{array}$ & & & & & \\
\hline 12 & $\begin{array}{l}\text { Toda a equipe de saúde do meu serviço } \\
\text { participa da formação de estudantes. }\end{array}$ & & & & & \\
\hline 13 & $\begin{array}{l}\text { Participo dos espaços de discussão da } \\
\text { integração ensino-serviço. }\end{array}$ & & & & & \\
\hline
\end{tabular}




\begin{tabular}{|c|c|c|c|c|c|c|}
\hline & Afirmativa & CT & $\mathbf{C P}$ & $\mathbf{I}$ & DP & DT \\
\hline 14 & $\begin{array}{l}\text { Minhas atividades no serviço foram } \\
\text { reorganizadas em função da presença dos } \\
\text { estudantes. }\end{array}$ & & & & & \\
\hline 15 & $\begin{array}{l}\text { Conheço o currículo do curso no qual sou } \\
\text { preceptor. }\end{array}$ & & & & & \\
\hline 16 & $\begin{array}{l}\text { A presença do estudante no serviço } \\
\text { compromete a segurança do paciente. }\end{array}$ & & & & & \\
\hline 17 & $\begin{array}{l}\text { Minha atividade de preceptoria é reconhecida } \\
\text { pelos profissionais da instituição de ensino } \\
\text { superior. }\end{array}$ & & & & & \\
\hline 18 & $\begin{array}{l}\text { A minha prática permite articular aspectos } \\
\text { biológicos, sociais e culturais do processo } \\
\text { saúde-doença. }\end{array}$ & & & & & \\
\hline 19 & $\begin{array}{l}\text { Identifico necessidades de saúde da } \\
\text { população que tendo para definir objetivos } \\
\text { educacionais. }\end{array}$ & & & & & \\
\hline 20 & $\begin{array}{l}\text { Meus objetivos educacionais não levam em } \\
\text { conta as necessidades de saúde da } \\
\text { população. }\end{array}$ & & & & & \\
\hline 21 & $\begin{array}{l}\text { Utilizo bases de dados para me manter } \\
\text { atualizado. }\end{array}$ & & & & & \\
\hline 22 & $\begin{array}{l}\text { Meus objetivos educacionais envolvem } \\
\text { atitudes, habilidades e conhecimentos. }\end{array}$ & & & & & \\
\hline 23 & $\begin{array}{l}\text { Conheço meu estudante e considero seus } \\
\text { conhecimentos prévios. }\end{array}$ & & & & & \\
\hline 24 & $\begin{array}{l}\text { Faço correlação teórico-prática na } \\
\text { preceptoria. }\end{array}$ & & & & & \\
\hline 25 & $\begin{array}{l}\text { Percebo minhas necessidades de } \\
\text { aprendizagem. }\end{array}$ & & & & & \\
\hline 26 & Avalio constantemente meu estudante. & & & & & \\
\hline 27 & Avalio o estudante ao final do processo. & & & & & \\
\hline 28 & $\begin{array}{l}\text { A avaliação do estudante não é minha } \\
\text { responsabilidade. }\end{array}$ & & & & & \\
\hline 29 & Aprendo com meu estudante. & & & & & \\
\hline 30 & $\begin{array}{l}\text { Desenvolvo atividades de pesquisa junto aos } \\
\text { estudantes. }\end{array}$ & & & & & \\
\hline
\end{tabular}




\begin{tabular}{|c|l|l|l|l|l|l|}
\hline \multicolumn{2}{|c|}{ Afirmativa } & CT & CP & I & DP & DT \\
\hline 31 & $\begin{array}{l}\text { A presença do estudante no serviço gera } \\
\text { conflitos dentro da equipe. }\end{array}$ & & & & & \\
\hline 32 & $\begin{array}{l}\text { O espaço físico do meu trabalho é adequado à } \\
\text { preceptoria. }\end{array}$ & & & & & \\
\hline 33 & Sou remunerado para ser preceptor. & & & & & \\
\hline 34 & Tenho interesse em seguir carreira docente. & & & & & \\
\hline 35 & $\begin{array}{l}\text { Minha função de preceptor melhora minha } \\
\text { qualidade de vida. }\end{array}$ & & & & & \\
\hline
\end{tabular}

36 - O que é preceptoria?

37 - Qual é a sua percepção do papel social desempenhado pelo preceptor? 
Anexo E: Termo de Consentimento Livre Esclarecido

Termo de Consentimento Livre Esclarecido

Estudo: Preceptores do Sistema Único de Saúde: como percebem seu papel em processos educacionais na saúde

DADOS DE IDENTIFICAÇÃO DO SUJEITO DA PESQUISA

NOME:

DOCUMENTO DE IDENTIDADE №:

SEXO: $M \square \quad F \quad \square$

DATA NASCIMENTO:

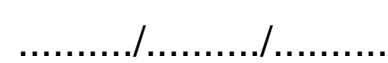

ENDEREÇO

BAIRRO:

CEP:

CIDADE:

TELEFONE:(.......)

Estimado(a) Especializando(a),

O presente tem como objetivo geral analisar a visão dos preceptores acerca do processo de ensino-aprendizagem e de seu papel social. Seus objetivos específicos são: (1) Analisar como os preceptores que participam do curso compreendem o processo de ensino-aprendizagem no qual estão inseridos; (2) Avaliar o que os preceptores entendem por preceptoria; (3) Avaliar como os preceptores entendem seu papel social perante a formação dos profissionais de saúde; (4) Comparar resultados obtidos em cada uma das regiões de saúde; (5) Comparar suas respostas no início do Curso de Especialização em Educação na Saúde para Preceptores do SUS e ao seu término, após o período de dez meses; (6) Analisar o conteúdo dos seus projetos aplicativos. 
Para que possamos realizar a avaliação, apresentamos um formulário eletrônico a ser preenchido por você com duas questões abertas e trinta e cinco questões fechadas.

Os riscos oferecidos por participar deste estudo são de nível mínimo, visto que a participação é voluntária. Os riscos de vazamento de informações por estarem armazenadas na internet também são mínimos, uma vez que normas de segurança on-line serão seguidas.

Sua participação nesta pesquisa será confidencial e os registros das suas respostas - registradas no mencionado formulário - serão utilizados para os fins de pesquisa acadêmica. Os resultados gerais poderão ser publicados em revistas acadêmicas, garantindo sempre o sigilo e anonimato dos participantes e servindo apenas como meio de divulgação científica dos resultados.

Você tem o direito de fazer quaisquer perguntas referentes aos riscos e obtenção de esclarecimentos durante sua participação nesta pesquisa, bem como a liberdade de recusar ou retirar o seu consentimento, em qualquer fase da mesma, sem penalização e sem prejuízo algum, bastando que solicite a exclusão de seus dados através de e-mail, enviado para qualquer um dos membros da equipe pesquisadora.

Tendo conhecimento dos fins acadêmicos desta pesquisa e pelo fato da participação dos sujeitos da pesquisa ser voluntária, não haverá nenhum tipo de ressarcimento ou indenização para o pesquisador ou para o pesquisando. 
No caso de qualquer dúvida, você poderá entrar em contato com um dos membros da equipe pesquisadora. Para tanto, seguem contatos:

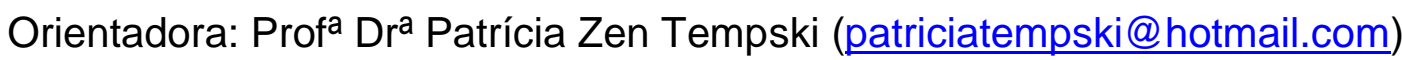
Mestranda: Letícia Cabrini Girotto (legirotto@hotmail.com)

Acredito ter sido suficientemente informado a respeito das informações que li ou que foram lidas para mim, descrevendo o estudo " Preceptores do Sistema Único de Saúde: visão do processo de aprendizagem e do seu papel social". Concordo voluntariamente em participar deste estudo e poderei retirar o meu consentimento a qualquer momento, antes ou durante 0 mesmo, sem penalidades ou prejuízo.

Assinatura do participante

Data

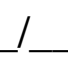

(Somente para o responsável do projeto)

Declaro que obtive de forma apropriada e voluntária o Consentimento Livre e Esclarecido deste paciente ou representante legal para a participação neste estudo.

Assinatura do responsável pelo estudo

Data 1 


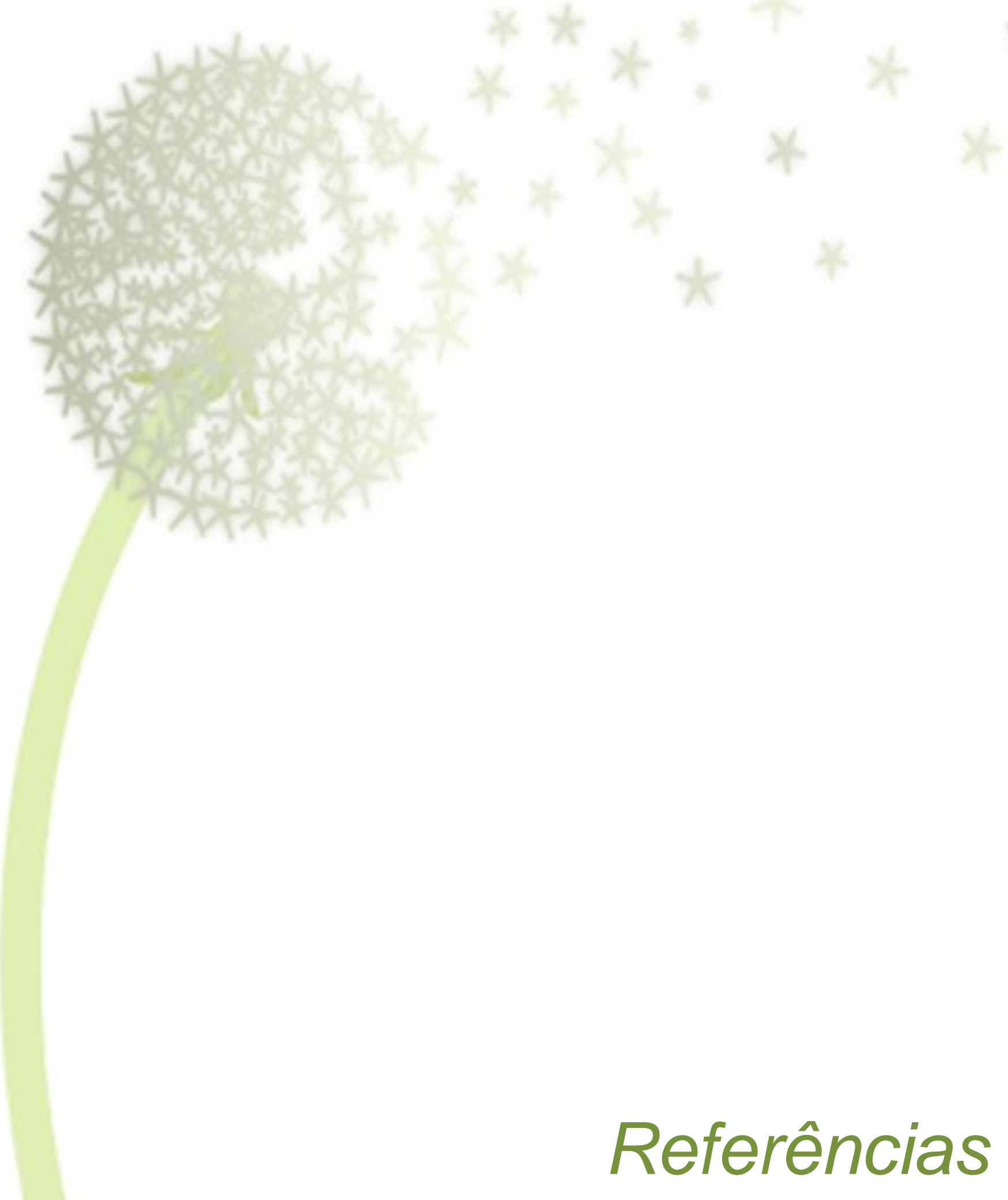




\section{Referências}

1. Brasil. Resolução CNE/CES $n^{\circ} 4$, de 7 de novembro de 2001. Institui as Diretirzes Curriculares Nacionais do Curso de Graduação em Medicina. 2001 p. 1-6.

2. Cecílio LCO. As necessidades de saúde como conceito estruturante na luta pela integralidade e equidade na atenção. In: Pinheiro R; Mattos, RA (Orgs.) Os sentidos da integralidade na atenção e no cuidado à saúde. Rio de Janeiro: IMS/UERJ - ABRASCO. 2001. p. 113-27.

3. Corlett J. The perceptions of nurse teachers, student nurses and preceptors of the theory-practice gap in nurse education. Nurse Educ Today.20(6):499-505;2000. Disponível em: http://www.sciencedirect.com/science/article/pii/S0260691799904148. Acesso em 25/05/2015.

4. Koifman L, Saippa-Oliveira G. As práticas de avaliação da formação e do cuidado orientadas pela integralidade: uma aproximação necessária. In: Pinheiro R; Mattos RA (Orgs) Gestão em redes: práticas de avaliação, formação e participação na saúde. 2006. p. 245-60.

5. Maeshiro R, Johnson I, Koo D, Parboosingh J, Carney JK, Gesundheit N, et al. Medical education for a healthier population: reflections on the Flexner Report from a public health perspective. Acad Med [Internet]. 2010 Feb [cited 2015 Jun 25];85(2):211-9. Available from: http://www.ncbi.nlm.nih.gov/pubmed/20107345

6. Cohen JJ. Defining international standards in basic medical education: The World Federation for Medical Education has initiated a timely discussion. Med Educ [Internet]. 2000 Aug [cited 2015 Jun 25];34(8):6001. Available from: http://doi.wiley.com/10.1046/j.1365-2923.2000.00741.x

7. Riddle MC, Lin J, Steinman JB, Salvi JD, Reynolds MM, Kastor AS, et al. Incorporating the principles of the patient-centered medical home into a student-run free clinic. Adv Med Educ Pract [Internet]. 2014 Jan [cited 2015 Jun 25];5:289-97. Available from: http://www.pubmedcentral.nih.gov/articlerender.fcgi?artid=4166215\&tool= 
pmcentrez\&rendertype =abstract

8. Scott SM, Schifferdecker KE, Anthony D, Chao J, Chessman AW, Margo $\mathrm{K}$, et al. Contemporary teaching strategies of exemplary community preceptors--is technology helping? Fam Med [Internet]. 2014 Jan [cited 2015 Jun 25];46(10):776-82. Available from: http://www.ncbi.nlm.nih.gov/pubmed/25646828

9. World Federation for Medical Education. Postgraduate Medical Education. WFME Global Standards for Quality Improvement. Med Educ. 2003.

10. Brasil. Resolução $n^{0} 3$, de 20 de junho de 2014. Institui as Diretrizes Curriculares Nacionais do Curso de Graduação em Medicina e dá outras providências. 2014 p. 8-11.

11. Council General Medical. Tomorrow's Doctors. Outcomes and standards for undergraduate medical education. 2009 p. 108.

12. Ceccim RB, Feuerwerker LCM. O Quadrilátero da Formação para a Área da Saúde : Ensino, Gestão, Atenção e Controle Social. Physis Rev Saúde Coletiva. 2004;14(1):41-65.

13. Blanco DF. O Conceito de Revolução Científica em Kuhn. http://www.arcos.org.br/artigos/o-conceito-de-revolucao-cientifica-emkuhn/.

14. Heffernan C, Heffernan E, Brosnan M, Brown G. Evaluating a preceptorship programme in South West Ireland: perceptions of preceptors and undergraduate students. J Nurs Manag [Internet]. 2009 Jul [cited 2015 Jun 25];17(5):539-49. Available from: http://www.ncbi.nlm.nih.gov/pubmed/19575712

15. van der Leeuw RM, Lombarts KM, Arah O a, Heineman MJ. A systematic review of the effects of residency training on patient outcomes. BMC Med [Internet]. BioMed Central Ltd; 2012;10(1):65. Available from: http://www.biomedcentral.com/1741-7015/10/65

16. Simões JC. O que o preceptor Quíron pode ensinar ao preceptor da residência médica. In: Manual do preceptor da residência médica. 2011. p. 78.

17. Soares ACP, Maiorquim CR, Souza CRO, do Vale DNF, Fujimoto DR, 
Fagundes FP. A Importância da Regulamentação da Preceptoria para a Melhoria da Qualidade dos Programas de Residência Médica na Amazônia Ocidental. Cad da ABEM O Precept por ele mesmo. 2013;8:14-23.

18. Botti SH de O, Rego S. Preceptor, Supervisor, Tutor e Mentor: Quais são Seus Papéis ? Rev Bras Educ Médica. 2008;32(3):363-73.

19. Botti SH de O. O Papel do Preceptor na Formação de Médicos Residentes: um estudo de residências em especialidaders clínicas de um hospital de ensino. 2009.

20. Botti SH de O, Rego ST de A. Docente-clínico: o complexo papel do preceptor na residência médica. Physis Rev Saúde Coletiva. 2011;21(1):65-85.

21. Missaka H, Ribeiro VMB. A Preceptoria na Formação Médica: o que Dizem os Trabalhos nos Congressos Brasileiros de Educação Médica 2007-2009. Rev Bras Educ Médica. 2009;35(3):303-10.

22. Jesus JCM, Ribeiro VMB. Uma Avaliação do Processo de formação Pedagógica de Preceptores do Internato Médico. Rev Bras Educ Médica. 2009;36(2):153-61.

23. Carlson E. Critical friends: A way to develop preceptor competence? Nurse Educ Pract [Internet]. 2014 Dec [cited 2015 Jun 25];1-2. Available from:

http://www.sciencedirect.com/science/article/pii/S1471595314001711

24. Fulvio B. Teaching Future Nurses in the Clinical Setting. JONA. 2015;45(1):21-7.

25. Gusso G, Vanzolini ME, Martins M de A, Seiffert OMLB, Tempski PZ, Brenelli S. Programa de formação de preceptores da residência médica. 2014 p. 12.

26. Coates VE, Gormley E. Learning the practice of nursing: views about preceptorship. Nurse Educ Today. 1997;17:91-8.

27. Panzavecchia L, Pearce R. Are preceptors adequately prepared for their role in supporting newly quali fi ed staff? Nurse Educ Today [Internet]. Elsevier Ltd; 2014;34(7):1119-24. Available from: http://dx.doi.org/10.1016/j.nedt.2014.03.001 
28. Broadbent M, Moxham L, Sander T, Walker S, Dwyer T. Supporting bachelor of nursing students within the clinical environment: Perspectives of preceptors. Nurse Educ Pract [Internet]. Elsevier Ltd; 2014;14(4):4039. Available from: http://dx.doi.org/10.1016/j.nepr.2013.12.003

29. Merton R. The sociology of Science . London: University of Chicago Press. 1973.

30. Hilli Y, Melender H-L, Salmu M, Jonsén E. Being a preceptor-A Nordic qualitative study. Nurse Educ Today [Internet]. 2014 Dec [cited 2015 Jun 25];34(12):1420-4.Available from: http://www.sciencedirect.com/science/article/pii/S0260691714001245.

31. Mills J, Francis K, Bonner A. Mentoning, clinical supervision and preceptoring. Rural Remote Health [Internet]. 2005;5(410). Available from: http://www.rrh.org.au

32. Jokelainen $M$, Turunen $H$, Tossavainen $K$, Jamookeeah $D$, Coco K. A systematic review of mentoring nursing students in clinical placements. $J$ Clin Nurs. 2011;20:2854-67.

33. Dent JA. Bedside teaching. In: Dent, J A; Harden, R M (Ed) A practical guide for medical teachers. 2009. p. 96-103.

34. Simões JC, Maeda AK. O preceptor de residência médica: esta figura (in)discutível. In: Manual do preceptor da residência médica. 2011. p. 78.

35. Freire P. Pedagogia da autonomia: saberes necessários à prática educativa. 2014. $144 \mathrm{p}$.

36. Rego TC. Vygotsky: uma perspectiva histórico-cultural da educação. Petrópolis: Vozes. 2011. 139 p.

37. Billay D, Myrick F. Preceptorship: An integrative review of the literature. Nurse Educ Pract. 2008;8:258-66.

38. Rose SR. The utilization and role of the preceptor in undergraduate nursing programs. Teach Learn Nurs. 2008;3:105-7.

39. Afonso $\mathrm{DH}$, Silveira LMC. Os desafios na formação de futuros preceptores no contexto de reorientação da educação médica. Rev Hosp Univ Pedro Ernesto. 2012;11:81-6.

40. Wuillaume SM, Batista NA. O preceptor na residência médica em Pediatria: principais atributos. J Pediatr (Rio J). 2000;76(5):333-8. 
41. Brasil. Lei $n^{\circ} 8.080$, de 19 de setembro de 1990. Dispõe sobre as condições para a promoção, proteção e recuperação da saúde, a organização e o funcionamento dos serviços correspondentes e dá outras providências. 1990 p. 1-13.

42. Brasil. Comissão Nacional de Residência Multiprofissional em Saúde. Resolução n. 2 SES/CNRMS, de 13 de abril de 2012. Dispõe sobre diretrizes gerais para os Programas de Residência Multiprofissional e em Profissional de saúde. 2012 p. Diário Oficial da União; Poder Executivo, Brasília.

43. Saúde. BCN de RM em. Resolução n. 5 SES/CNRM, de 08 de junho de 2004. Dispõe sobre os programas de preceptor/tutor de residência médica. 2004 p. Diário Oficial da União; Poder Executivo, Brasília.

44. Brasil. Lei $n^{0} 12.871$, de 22 de outubro de 2013. Institui o Programa Mais Médicos, altera as Leis $n^{0} 8.745$, de 9 de dezembro de 1993, e ${ }^{\circ} 6.932$, de 7 de julho de 1981, e dá outras providências. 2013.

45. Souza APTC, Siqueira ES, Fernandes G, Correia IB, Araújo Júnior JGC. Residência Médica em Pernambuco: reflexões de um grupo de preceptores sobre cenários e atores. Cad da ABEM O Precept por ele mesmo. 2013;8:77-86.

46. Moraes VA, Pereira ERS, Naghettini AV. Quais e Como Devem Ser os Cenários de Ensino-Aprendizagem segundo o Perfil do Egresso Proposto nas Diretrizes Curriculares Nacionais. In: Streit, DS et al (orgs) Educação Médica: 10 Anos de Diretrizes Curriculares Nacionais. 2012. p. 250.

47. Carvalho YM, Ceccim RB. Formação e Educação em Saúde: aprendizados com a Saúde Coletiva. In: In: CAMPOS, G W S; et al Tratado de saúde coletiva Rio de Janeiro: Hucitec; Fiocruz. 2006. p. 135.

48. Harden R, Laidlaw J. Essencial Skills for Medical Teacher: an introduction to teaching and learning in medicine. London: Elselvier. 2012.

49. Beltrame RL. O ensino médico. In: Perseverando na reformulação do ensino médico. 2013.

50. Tempski PZ, Martins MA. O Papel da Avaliação de Habilidades Clínicas na Educação Médica no Brasil. In: Avaliação Prática de Habilidades 
Clínicas em Medicina São Paulo: Atheneu. 2012.

51. Aguiar RAT. A universidade e as políticas de educação permanente para a estratégia saúde da família: um estudo de caso. 2010.

52. Organizacion Panamericana de la Salud. Infome Dawson. 1964 p. 46.

53. Brasil. Lei $\mathrm{n}^{0} 5.540$, de 28 de novembro de 1968. Fixa normas de organização e funcionamento do ensino superior e sua articulação com a escola média, e dá outras providências. 1996 p. 20-2.

54. Lalonde M. A New Perspective on the health of canadians. 1981.

55. WHO. Declaration of Alma-Ata. 2000 p. 3.

56. Hall JJ, Taylor R. Health for all beyond 2000 : the demise of the Alma-Ata Declaration and primary health care in developing countries. Glob Heal. 2003;178(January):17-20.

57. Batista NA, Souza da Silva SH. O ensino médico e sua trajetória no cenário nacional. In: O professor de medicina. 1998.

58. Feuerwerker LCM, Costa H, Rangel ML. Diversificação de cenários de ensino e trabalho sobre necessidades/problemas das comunidades. Divulg em Saúde para Debate. 2000;12:9-17.

59. Brasil. Constituição da República Federativa do Brasil. 1988 p. 47.

60. Brasil. Promed. Programa de Incentivo a Mudanças Curriculares nos Cursos de Medicina. 2002 p. 78.

61. Brasil. AprenderSUS: O SUS e os Cursos de Graduação da Área da Saúde. 2004 p. 11.

62. WHO. WHO / WFME Guidelines for Accreditation of Basic Medical Education. 2005 p. 14.

63. Brasil. Programa Nacional de Reorientação da Formação Profissional em Saúde - PRÓ-SAÚDE. 2007 p. 80.

64. Brasil. Medida Provisória 621 de 8 de julho de 2013. Institui o Programa Mais Médicos e dá outras providências. 2013 p. 1-3.

65. Lefrançois GR. Teorias da aprendizagem (Tradução da 5.ed). 2008. $504 p$.

66. Tempski PZ, Martins M de A. Modelos teóricos do processo ensinoaprendizagem aplicados às estratégias educacionais de simulação. In: Scalabrini Neto, Augusto (Org) Simulação realística e treinamento de 
habilidades(no prelo).

67. Saviani D. As concepções pedagógicas na história da educação brasileira [Internet]. Texto elaborado no âmbito do projeto de pesquisa "O espaço acadêmico da pedagogia no Brasil." 2005. Available from: http://d.yimg.com/kq/groups/17386083/498086524/name/ASCONCEP\% 3\%83\%E2\%80\%A1\%C3\%83\%E2\%80\%A2ESPEDAG\%C3\%83\%E2\%80 \%9CGICASNAHIST\%C3\%83\%E2\%80\%9CRIADAEDUCA\%C3\%83\%E2 \%80\%A1\%C3\%83\%C6\%920 BRASILEIRA.pdf

68. Negrão AMM. Resenha de "O método pedagógico dos jesuítas: o "Ratio Studiorum", de Leonel Franca SJ. Rev Bras Educ. 2000;14:154-7.

69. Anastasiou LGC. Metodologia de ensino na universidade brasileira: elementos de uma trajetória. In: Castanho ME, Castanho S Temas e Textos da Educação Superior, Campinas. 2001.

70. Ahlert A. Educação, ética e cidadania em Johann Amos Comenius: aproximações com Paulo Freire. 2006;84-94.

71. Carvalho JA, Carvalho MP, Barreto MAM, Alves FA. Andragogia: Considerações sobre a aprendizagem do adulto. Rev Eletrônica do Mestr Prof em Ensino Ciências da Saúde e do Ambient. 2010;3(1):78-90.

72. Jobim e Souza S, Kramer S. O debate Piaget/Vygotsky e as políticas educacionais. Cad Pesq. 1991;77:69-80.

73. Bransford J, Brown A, Cocking R, editors. How people learn: brain, mind, experience and school. Washington, DC: National Academy Press; 2000. $374 \mathrm{p}$.

74. Perrenoud P. Construir as competências desde a escola Philippe. Porto Alegre: Artmed. 1999. 101 p.

75. Tempski P, Padilha RQ, Lima VV, Oliveira MS, Silva SF, Caleman G, et al. Educação na Saúde para Preceptores do SUS. Caderno do curso. Instituto Sírio Libanês de Ensino e Pesquisa. 2013.

76. Cramer JA. Principles of health-related quality of life: assessment in clinical trials. Epilepsia [Internet]. 2002;43(9):1084-95. Available from: http://www.ncbi.nlm.nih.gov/pubmed/12199735

77. Bland JM, Altman DG. Statistics Notes: Cronbach's Alpha. Br Med J. 1997;314(7080):22-3. 
78. Smith S, Lamping D, Banerjee S, Harwood R, Foley B, Smith P, et al. Measurement of health-related quality of life for people with dementia: development of a new instrument (DEMQOL) and an evaluation of current methodology. Health Technol Assess. 2005;9(10):1-93.

79. Fiedler PT. Avaliação da qualidade de vida do estudante de medicina e da influência exercida pela formação acadêmica. 2008.

80. Enns SC. Avaliação da percepção do ambiente de ensino e sua relação com a qualidade de vida em estudantes de medicina. 2014.

81. Turato ER. Tratado da Metodologia da Pesquisa Clínico-Qualitativa. Petrópolis: Editora Vozes. 2003.

82. Bardin L. Análise do conteúdo. Lisboa: Edições 70. 1995.

83. Denzin N, Lincoln YS. O Planejamento da pesquisa qualitativa Teoria e Abordagens. Porto Alegre: Artmed. 2006.

84. Debus M. Manual para excelência en la investigación mediante grupos focales. Washington: Academy of Educational Development. 1997.

85. Brasil. Portaria Interministerial $n^{0} 1.618$, de 30 de setembro de 2015, que institui o Plano Nacional de Formação de Preceptores para os Programas de Residência em Medicina Geral de Família e Comunidade. 2015.

86. Tempski $P$ et al. Curso de capacitação em preceptoria de residência médica: Caderno do Curso. 2015.

87. Kilminster S, Downes J, Gough B, Murdoch-eaton D, Roberts T. Women in medicine - is there a problem? A literature rewiew of the chaning gender composition, structures and occupational cultures in medicine. Med Educ. 2007;41:39-49.

88. Verlander G. Female Physicians: Balancing Career and Family. Acad Psychiatry. 2004;28(4):331-6.

89. Brasil. Lei n. 11.129 de 30 de junho de 2005. Institui o Programa Nacional de Inclusão de Jovens - ProJovem; cria o Conselho Nacional da Juventude - CNJ e a Secretaria Nacional de Juventude; altera as leis n. 10.683 de 28 de maio de 2003 e 10.429 de 24 de abril d. 2005.

90. Brasil. Lei n. 6932 de 7 de julho de 1981. Dispõe sobre as atividades do médico residente e dá outras providências. 1981.

91. Almeida da Silva JC, Zimmer LR. Parecer CNE/CES n. 67/2003. 
Referencial para as Diretrizes Curriculares Nacionais - DCN dos Cursos de Graduação. 2003 p. 1-9.

92. Almeida M. Diretrizes Curriculares Nacionais para os Cursos Universitários da Área da Saúde. Londrina: Rede Unida. 2003.

93. Marins JJN, Rego S, Lampert JB, Araújo JGC. Educação médica em transformação: instrumentos para a construção de novas realidades. Editora Hucitec. 2004. 390 p.

94. Knowles MS. The Adult Learner: A Neglected Species. Houston: Gulf Publishing Company. 1990.

95. Ausubel D. Educational Psychology; a cognitive view. NY: Holt, Reinhard and Winston. 1968.

96. Berbel NAN. A problematização e a aprendizagem baseada em problemas: diferentes termos ou diferentes caminhos? Interface Comunic, Saúde, Educ. 1998;2(2):139-54.

97. Freire P. Educação e mudança. 13a. ed. Paz e Terra; 1997. 112 p.

98. Perrenoud P. Construir Competências é Virar as Costas aos Saberes? Rev Pedagógica Pátio [Internet]. 1999;15-9. Available from: http://egov.ufsc.br/portal/sites/default/files/anexos/29108-29126-1-PB.pdf

99. Harden R, Crosby J. The good teacher ir more than a lecturer - The twelve roles of the teacher. Med Teach. 2000;22:334-47.

100. Forneris SG, Peden-mcalpine C. Creating context for critical thinking in practice: the role of the preceptor. J Adv Nurs. 2009;65(8):1715-24.

101. Marks-Maran D, Ooms A, Tapping J, Muir J, Phillips S, Burke L. A preceptorship programme for newly qualified nurses: A study of preceptees' perceptions. Nurse Educ Today. 2013;33(11):1428-34.

102. Albuquerque VS, Gomes AP, Rezende CHA, Sampaio MX, Dias OV, Lugarinho RM. A Integração Ensino-serviço no Contexto dos Processos de Mudança na Formação Superior dos Profissionais da Saúde. Rev Bras Educ Médica. 2008;32(3):356-62.

103. Lima VV. Competência : distintas abordagens e implicações na formação de profissionais de saúde. Interface - Comunic, Saúde, Educ. 2005;9(17):369-79.

104. Cavalheiro MTP, Guimarães AL. Formação para o SUS e os Desafios da 
Integração Ensino Serviço. Cad FNEPAS. 2011;1:19-27.

105. Dobalian A, Bowman CC, Wyte-Lake T, Pearson ML, Dougherty MB, Needleman J. The critical elements of effective academic-practice partnerships: a framework derived from the Department of Veterans Affairs Nursing Academy. BMC Nurs [Internet]. 2014;13(1):1-17. Available from: http://www.biomedcentral.com/1472-6955/13/36

106. Kaviani N, Stillwell Y. An evaluative study of clinical preceptorship. Nurse Educ Today. 2000;20(3):218-26.

107. Manyon A, Shipengrover J, MacGuigan D, Haggerty M, James P, Dan Zo A. Defining differences in the instructional styles of community preceptors. Med Student Educ. 2003;35(3):181-6.

108. Nascimento DDG. A Residência Multiprofissional em Saúde da Família como Estratégia de Formação da Força de Trabalho para o SUS. 2008. 